\title{
Societal need for improved understanding of climate change, anthropogenic impacts, and geo-hazard warning drive development of ocean observatories in European Seas
}

\author{
Henry A. Ruhla, *, Michel André ${ }^{b}$, Laura Beranzoli ${ }^{c}$, M. Namik Çağatay ${ }^{d}$, Ana Colaço ${ }^{e}$, \\ Mathilde Cannat ${ }^{\mathrm{f}}$, Juanjo J. Dañobeitia ${ }^{g}$, Paolo Favali ${ }^{\mathrm{c}}$, Louis Géli ${ }^{\mathrm{h}}$, Michael Gillooly', Jens Greinert', \\ Per O.J. Hall ${ }^{k}$, Robert Huber, Johannes Karstensen ${ }^{m}$, Richard S. Lampitt ${ }^{a}$, Kate E. Larkin ${ }^{a}$, \\ Vasilios Lykousis $^{n}$, Jürgen Mienert ${ }^{\mathrm{D}}, \mathrm{J}$. Miguel Miranda ${ }^{\mathrm{p}}$, Roland Person ${ }^{\mathrm{h}}$, Imants G. Priede ${ }^{\mathrm{q}}$, \\ Ingrid Puillat ${ }^{\mathrm{h}}$, Laurenz Thomsen ${ }^{\mathrm{r}}$, Christoph Waldmann
}

\footnotetext{
a National Oceanography Centre, Southampton, University of Southampton Waterfront Campus, European Way, Southampton SO14 3ZH, United Kingdom

b Laboratori d'Aplicacions Bioacústiques, Universitat Politècnica de Catalunya, Centre Tecnològic de Vilanova i la Geltrú, Avda. Rambla Exposició, s/n, 08800 Vilanova i la Geltrú, Barcelona, Spain

c Istituto Nazionale di Geofisica e Vulcanologia, Via di Vigna Murata, 695-00143 Roma, Italy

d Istanbul Technical University, Istanbul, Turkey

e IMAR, Department of Oceanography and Fisheries, University of Azores, Cais de Sta Cruz, 9901862 Horta, Portugal

f Laboratoire de Géosciences Marines, Institut de Physique du Globe de Paris, 4 Place Jussieu, 75252 Paris, France

g Unidad de Tecnologia Marina, Consejo Superior de Investigaciones Científicas, Barcelona, Spain

${ }^{\mathrm{h}}$ Ifremer, 29280 Plouzané, France

i Marine Institute Headquarters, Rinville, Oranmore, Co. Galway, Ireland

j Royal Netherlands Institute for Sea Research, P.O. Box 59, 1790 AB Den Burg, Texel, The Netherlands

k Department of Chemistry, Marine Chemistry, University of Gothenburg, SE-412 96 Gothenburg, Sweden

'MARUM-Center for Marine Environmental Sciences, University of Bremen, Klagenfurter Str., 28359 Bremen, Germany

${ }^{m}$ Leibniz-Institut für Meereswissenschaften an der Universität Kiel, Düsternbrooker Weg 20, 24105 Kiel, Germany

n Marine Geology, Hellenic Centre for Marine Research, 47km, Athens-Sounio Avenue, Anavyssos, 19013 Athens, Attiki, Greece

${ }^{\circ}$ Department of Geology, University of Tromsø, Dramsveien 201, N-9037 Troms $\varnothing$, Norway

${ }^{p}$ Centro de Geofisica, Universidade de Lisboa, Campo Grande, Ed C8, 1749-016 Lisboa, Portugal

${ }^{q}$ University of Aberdeen, Oceanlab, Newburgh, Aberdeen AB41 6AA, United Kingdom

r Jacobs University Bremen, Campus Ring 1, 28759 Bremen, Germany
}

\footnotetext{
*: Corresponding author : Henry A. Ruhl, Tel.: +44 (0) 2380596365 ; fax: +44 (0) 2380596247 ; email address : h.ruhl@noc.soton.ac.uk
} 


\section{Abstract:}

Society's needs for a network of in situ ocean observing systems cross many areas of earth and marine science. Here we review the science themes that benefit from data supplied from ocean observatories. Understanding from existing studies is fragmented to the extent that it lacks the coherent long-term monitoring needed to address questions at the scales essential to understand climate change and improve geo-hazard early warning. Data sets from the deep sea are particularly rare with long-term data available from only a few locations worldwide. These science areas have impacts on societal health and well-being and our awareness of ocean function in a shifting climate.

Substantial efforts are underway to realise a network of open-ocean observatories around European Seas that will operate over multiple decades. Some systems are already collecting high-resolution data from surface, water column, seafloor, and sub-seafloor sensors linked to shore by satellite or cable connection in real or near-real time, along with samples and other data collected in a delayed mode. We expect that such observatories will contribute to answering major ocean science questions including: How can monitoring of factors such as seismic activity, pore fluid chemistry and pressure, and gas hydrate stability improve seismic, slope failure, and tsunami warning? What aspects of physical oceanography, biogeochemical cycling, and ecosystems will be most sensitive to climatic and anthropogenic change? What are natural versus anthropogenic changes? Most fundamentally, how are marine processes that occur at differing scales related?

The development of ocean observatories provides a substantial opportunity for ocean science to evolve in Europe. Here we also describe some basic attributes of network design. Observatory networks provide the means to coordinate and integrate the collection of standardised data capable of bridging measurement scales across a dispersed area in European Seas adding needed certainty to estimates of future oceanic conditions. Observatory data can be analysed along with other data such as those from satellites, drifting floats, autonomous underwater vehicles, model analysis, and the known distribution and abundances of marine fauna in order to address some of the questions posed above. Standardised methods for information management are also becoming established to ensure better accessibility and traceability of these data sets and ultimately to increase their use for societal benefit. The connection of ocean observatory effort into larger frameworks including the Global Earth Observation System of Systems (GEOSS) and the Global Monitoring of Environment and Security (GMES) is integral to its success. It is in a greater integrated framework that the full potential of the component systems will be realised.

\section{Highlights}

Societies increasingly depend on timely information on ecosystems and natural hazards. Data is needed to improve climate-related uncertainty and geo-hazard early warning. Observatory networks coordinate and integrate the collection of standardised data. Ocean observatories provide opportunity for ocean science to evolve.

Keywords: geological hazards, climate change, biological pump, biogeochemical cycles, ecosystem function, long-term changes, ocean observatory 


\section{Introduction}

European researchers are developing a means to address a growing set of earth science questions that require a broad and integrated network of ocean and seafloor observation. The need to resolve patterns and processes across many time and space scales has pushed development of several earth and ocean observing programmes worldwide that integrate a variety of tools. Earth and ocean processes indeed operate on scales from a fraction of a second to decades or more (Fig. 1) and extend from the atmosphere to the sub-seafloor (Fig. 2). There is now wide recognition that research addressing science questions of international priority, such as understanding potential impacts of climate change or geo-hazards such as earthquakes and tsunamis, should be done in a framework that can effectively address questions across those scales (NRC 2000, Priede et al., 2003, 2005, Favali and Beranzoli 2006, Barnes et al. 2008).

In situ observation is essential to forming and revising experimental and model frameworks. Maintaining observation of key ocean science variables over long timescales with adequate temporal resolution has been challenging with many only lasting a few years or less. Marine time-series data constitute a minor fraction of existing data sets available for studying the climatic influences with very little data available from the deep sea (Glover et al. 2010). Measurements by research ship provide valuable information, but are limited to fairer weather conditions, and are too infrequent to characterise most processes, often neglecting important extremes. Even where time-series data sets have been available, between-site comparisons and larger-scale assessments have rarely been straightforward. Industrial activities and their impacts are nonetheless progressing into deeper waters where even basic processes are poorly understood. Estimating future ocean conditions requires improved scientific assessment of process limiting factors, particularly for ephemeral features. Enhanced integration of spatial and temporal process resesrch is also needed.

It is clear that more vigilant monitoring is necessary over longer durations and with greater continuity. The Intergovernmental Panel on Climate Change estimates that global warming will continue for centuries and will have pervasive impacts for society (IPCC 2007a, b). The international Group on Earth Observing (GEO), Global Earth Observation System of Systems (GEOSS), Global Ocean Observing System (GOOS), and OceanSITES are organisations and programmes that aim to bridge governmental, planning, and knowledge gaps. Existing European ocean observatories have begun to contribute to GEOSS and the Global Monitoring of Environment and Security (GMES) programme. Partnerships with industries already operating in European seas are also beginning to add breadth and quality to observation and logistical support. Site activity stretches from the Arctic Ocean near Svalbard to the mid Atlantic Ridge, and eastward through the Mediterranean to the Black Sea. Through hierarchical connections to GEOSS, observatories in these areas can integrate with coastal and terrestrial systems. Planning is now progressing in several areas with projects underway demonstrating how researchers, institutes, and industrial partners can work together on various network facets. The efforts include outlining objectives and design requirements, conducting research, standardising and augmenting existing systems, and addressing the logistical and governance challenges of developing the needed systems.

Human societies depend more and more on accurate and timely information on climate, weather, water, ecosystems, biodiversity, energy resources, and natural disasters. Here we outline major international science priorities in the four interconnected fields of geoscience, physical oceanography, biogeochemistry, and marine ecology, which will be advanced through observatory science. Efforts to outline relevant science objectives and design requirements have included the European Seafloor Observatory NETwork Concerted Action (ESONET CA; Priede et al. 2005), ESONET Network Implementation Model 
(ESONIM), the Deep-Sea Frontier initiative (European Commission 2007), European Seas Observatory NETwork Network of Excellence (ESONET NoE), EuroSITES, and European Multidisciplinary Seafloor Observatory (EMSO) Preparatory Phase (Favali and Beranzoli, 2009), and the outputs of several other national and international ocean science projects and programmes (Table 1). These activities have been organising science requirement, logistical, fiscal, and legal aspects of building and operating dispersed ocean observatory networks.

With improved availability and consistency in measurements taken across European seas there will be a transformative shift in the ability to conduct cross-cutting science over a wide range of marine habitats. Proposed or active sites include those in abyssal plains, open slopes, seamounts, canyons, ridges, faults, fluid seeps, hydrothermal vents, gas hydrates, mud volcanoes, deep-sea corals, carbonate mounds, and potential geo-hazard zones. The sites also span the major biogeochemical provinces found in European waters (Fig. 3) with each site having more specialised science objectives depending on the setting.

Science objectives guide observatory design. In situ infrastructures include various arrangements like seafloor cables, moorings, landers, and vehicle systems. The modular designs being considered have two fundamental aspects with one addressing 'core' services like supply of data on temperature, salinity (conductivity), depth (pressure), and ocean currents and another that incorporates 'specific' data like seismicity, biogeochemical fluxes, and faunal abundances. The modular and expandable network can support highly specialised monitoring and experimental systems as needed. In order to address some objectives, fixed point systems will need support from satellites, climatic models, drifting floats, sea gliders, autonomous underwater vehicles, or the known distribution and abundances of marine fauna. Together these platforms provide a wide-ranging view of ocean dynamics over time and space.

Here we review science areas that relate to ocean observatory research and introduce some of the design concepts being considered. The broad-based approach to assessing the science objectives resulted in a vision of ocean observatories with substantial scope that is evolving ocean science in Europe. The integration of data from ocean observatory networks and other seismic, climatic and ecological systems in GEOSS and GMES has great potential to change the way in which researchers approach issues of great societal importance like climate change, natural resource utilisation, and environmental hazards.

\section{Science Objectives}

\subsection{Geosciences}

\subsubsection{Seismicity}

The solid earth holds many natural resources and its dynamics release massive amounts of energy in unpredictable ways. Intense geologic activity can result in catastrophic impacts on citizens, damage to offshore industry infrastructure, and ecosystem perturbations. Both earthquakes and submarine landslides can result in tsunamis with heights well above spring tide levels causing rapid flooding of coastal areas.

Earthquakes like those in Sichuan China in $2008\left(M_{w} 8\right)$ and offshore Sumatra in 2004 $\left(\mathrm{M}_{\mathrm{w}}\right.$ 9.3) resulted in hundreds of thousands of lost lives and millions more displaced (Lay et al. 2005, Stone 2008). Tsunamis have also struck American Samoa in September 2009 killing more than one thousand people and displacing thousands more, and Chile in 2010 with loss of life and displacement. European earthquakes at the Western Hellenic Trench (365 AD), Eastern Hellenic Trench (1303 AD), Catania (1693 AD), Lisbon (1775 AD), and Messina (1908 AD) and their resulting tsunamis are among the most destructive in recorded history 
(Boschi et al. 1997, Babtista et al. 1998, Piatanesi and Tinti 1998, Yalçiner et al. 2002, Tinti et al. 2004, Chester 2008).

The meeting of the Eurasian tectonic plate with African (Nubian) and Arabian plates along the southern Mediterranean, as well as the Eurasian and North American plates along the Mid Atlantic Ridge offer an opportunity to study solid earth processes across Europe (Fig. 4, Kreemer et al. 2003, Sgroi et al. 2007). In the Marmara Sea region there have been several recent earthquakes with the last of which was in 1999 that resulted in about 20,000 lost lives. The nature of the previous events in the Marmara Sea suggests that another major earthquake in the area is likely within the coming decades (Parsons et al. 2000, Parsons 2004). The Gulf of Corinth is another area of high seismic activity (Lykousis et al. 2007). Other European areas with major earthquake history include Italy, and even areas of France, the United Kingdom, Norway, and the Azores, Portugal have had contemporary activity greater than magnitude 5. The Aegean Sea has especially complex fault stress and resulting motions (Fig. 4B, Kreemer et al. 2003). Discerning plate subdivisions and fine scale motions can help to clarify kinetic links in seismic variations (Mantovani et al. 2007, Burrato et al. 2008). Although convergent, collision, and divergent spreading plate processes dominate the European area, transform sheer, and rotation also have importance. Seafloor spreading and associated submarine volcanoes, seismic activity, plate fracturing, hydrothermal venting, and diffuse fluid flow are all found in European seas.

\subsubsection{Gas hydrate stability}

Gas hydrates hold vast quantities of solid methane in marine sediments (Judd et al. 2002) and often outcrop in sloped areas (Paull et al. 2005). Seismic activity and warming can make gas hydrates unstable, which can increase slope instability and result in large releases of greenhouse gases that add positive feedback to global warming (Kennett et al. 2000, Mienert et al. 2000, Schmale et al. 2005, Greinert et al. 2006, Kessler et al. 2006, Archer 2007, Archer et al. 2009) and contribute to hypoxia in small semi-enclosed marine basins, such as the Iznit Gulf in the Sea of Marmara (Çağatay et al., 2008) and Gulf of Corinth (Marinaro et al. 2006). Active hydrate release is known to be occurring in the Black Sea, Mediterranean, Gulf of Cadiz, Nordic, and Arctic sites (Bohrmann et al. 2003, Woodside et al. 2006, Lykousis et al. 2009, Westbrook et al. 2009, Hustoft et al., 2009).

Ocean warming could have destabilising impacts on gas hydrate stability in areas where hydrates outcrop at the seabed, but few in situ data exist on hydrate disassociation dynamics. Gas emissions in the Arctic, an area projected to have relatively intense climate warming impacts, have already been documented (Fig. 5, IPCC 2007, Westbrook et al. 2009, Shakhova et al. 2009). Mechanisms for positive feedback between warming and release of methane have been described, but the lack of detailed observation limits budgeting (Judd et al. 2002, McGinnis et al. 2006).

Monitoring methane fluxes can aid in studying fluid-fault processes related to earthquakes (Görür and Çağatay, 2009), as can variation in sediment pore water pressure. Gas emissions related to active faults have successfully been mapped with acoustic methods in the Gulf of Corinth (Soter 1999) and Sea of Marmara (Géli et al. 2008). However, links between gas emissions, the seismic cycle and oceanic warming have to be understood more clearly (Etiope and Favali 2004). Preliminary results suggest it will be possible to test hypotheses related to systematic physical and chemical changes that occur throughout an earthquake cycle (e.g. Géli et al. 2008).

\subsubsection{Seabed fluid flow}

Fluid flow within and through the seabed transfers substantial amounts of mass, heat, and chemical energy and links to geophysical, biogeochemical, and ecological processes 
(Tryon et al. 2001). Determining long-term variations in heat and chemical fluxes of hydrothermal vents will be valuable for balancing geothermal and oceanic heat and chemical budgets from carbon to trace elements (Fouquet et al. 1995, Cannat et al. 1999). The throughput of hydrothermal venting systems has been estimated to be comparable with other deep-ocean circulation turnovers with the entire volume of the ocean potentially being circulated through such systems every few thousand years (German and Von Damm, 2006). These vents act as a sink for magnesium and sulphate whereas Fe and reduced species of $\mathrm{H}_{2}$, $\mathrm{CH}_{4}$ and $\mathrm{H}_{2} \mathrm{~S}$ can be released in expelled vent fluids. This dissolved iron is believed to be an important source of iron for primary production in surface waters (Bennett et al. 2008, Tagliabue et al. 2010). The reduced species can provide important energy sources for chemosynthetic species often found at hydrothermal vents. Recent modelling results suggest that mid-ocean ridge vents may expel fluids for an average of around three years, but this remains to be validated (Coumou et al. 2008).

Abiotic synthesis of hydrogen occurs in vent systems suggesting potential for research on the production of natural hydrogen as a source of energy for fuel cells. Elevated concentrations of methane at Mid-Atlantic Ridge vents have been linked to the presence of mantle rocks exposed on the seafloor that are undergoing serpentinisation reactions. These discoveries show that the abiotic synthesis of hydrogen and hydrocarbons may occur in deepsea environments in the presence of ultramafic rocks, water, and heat (e.g. Proskurowski et al. 2008).

Understanding fluid flow in deep-ocean sediments is important to the oil and gas industry for estimating production efficiency and averting unexpected dynamics in the behaviour of such fluids. Major uncertainty about behaviour of multiphase hydrocarbons in the deep sea remains including switches between solid, liquid, and gaseous states. The influence of dispersants used in accidents such as the Deepwater Horizon blowout in the Gulf of Mexico is also unknown. These uncertainties have hampered efforts to quantify the fate of oil and gas that leaked as a result of the accident (Camilli et al. 2010, Mezić et al. 2010). The efficacy of carbon capture and storage and implications for seabed fluid dynamics is also still in question (Shepherd et al. 2009, Blackford et al. 2009, Shaffer 2010).

\subsubsection{Seafloor-water column interactions and Submarine landslides}

Submarine landslides result in mass movements of material reshaping the seafloor, and can cause large tsunamis. Such slides can be caused by gas hydrate and seabed fluid stability and may be triggered by seismic events. Slides such as Nyk, Traenadjupet, and Storegga on the Norwegian margin are among the largest described (Mienert 2004, Mienert et al. 2004, Solheim et al. 2005, Micallef et al. 2008). The Storegga slide, for example, occurred off the central west coast of Norway about 8000 years ago and resulted in tsunami waves several metres high with devastating impacts as far south as the United Kingdom (Bondevik et al. 1997, Locat et al. 2003, Huhnerbach and Masson 2004).

Ridge crests, fjords, and submarine canyons are complex areas of sedimentary and fluid flow processes that influence the distribution and abundance of biogeochemical quantities and marine life (van Weering et al. 2002, Canals et al. 2006, St Laurent and Thurnherr 2007, Arzola et al. 2008, Bianchelli et al. 2008, Canals et al. 2009, Lastras et al. 2009). Changes in climate conditions, sea level, flooding, and seismic activity can transport large fluxes of fluids, sediment, and organic matter down slope (Christensen and Christensen 2003, Arzola et al. 2008, Leynaud et al. 2008). Measuring the evolution of seabed stability and sediment and organic matter transport processes offeres opportunities to improve geohazard understanding and constrains gaps in carbon budgets at the seafloor.

\subsubsection{Geo-hazard Early Warning}


Studies of geologically hazardous events ultimately aim to alleviate their impacts. Earthquake warnings of only minutes can make a major difference in the impact of hazardous events. Ocean and solid earth wave physics have achieved sufficient ability to locate emerging areas of fault activity and determine if the energy and characteristics of seismic events are hazardous. Semi-automated systems are basic components for the development of early warning systems providing policy makers with operational tools to reduce the impact on citizens living some distance away from the epicentre (Beranzoli et al. 2002, Blandin and Rolin 2005, Kanamori 2005, Frugoni et al. 2006, Lomax et al. 2007, Olivieri and Scognamiglio 2007).

New discoveries based on long-term, continuous monitoring should lead to improved probabilistic estimates of earthquake occurrence. As stress and instability accumulates detectable shifts in pressure, temperature, or chemistry of the porewater within sediments may be indicative of pending hazards such as earthquakes and slope failures (Berndt 2005, Micallef et al. 2008). High-resolution measurements should substantially aid in deciphering the factors that lead to earth motions and control geologic processes.

Currently less that $1 \%$ of the International Registry of Seismograph Stations operate below sea level even though the majority of Earth is covered by water several thousand meters deep. Furthermore only about $0.2 \%$ of these sensors are below $1000 \mathrm{~m}$ depth, none of which are located in European Seas (USGS, 2010). The integration of the European ocean observatory network with the European Plate Observing System (EPOS) infrastructure should prove transformational.

Tsunami warning systems have already been developed in the Pacific (Meinig et al. 2005) and Indian Oceans (GITEWS 2007). While such systems proved useful after the Chilean tsunami in 2010, wave height and arrival time models could not resolve if waves were hazardous after crossing the Pacific. This due in part to the fact that wave measurements used to build forecasts come almost exclusively from nearshore locations where waveforms differ from the open ocean. The Intergovernmental Oceanographic Commission programme Northeast Atlantic, Mediterranean and connected seas Tsunami Warning System (NEAMTWS) and the European Commission project Integrated Observations from Near Shore Sources of Tsunamis (NEAREST) are now planning for systems that will include open ocean nodes. The value of early warning systems is significant with tsunami wave heights that can reach well over $10 \mathrm{~m}$ in the Mediterranean Sea. As an example, the 1693 Catania earthquake caused the largest tsunami that flooded the coasts of Southern Italy with waves up to $13 \mathrm{~m}$ (Piatanesi and Tinti 1998; Tinti et al. 2004, Lorito et al. 2008).

\section{Key questions in understanding and monitoring of geophysics:}

Questions addressable with observatory systems:

- How can monitoring factors such as seismic activity, pore fluid chemistry and pressure, and gas-hydrate stability improve seismic, slope failure, and tsunami warning?

- What is the importance of oversteepening, storm and tide wave loading, sedimentation loading, gas charging, gas-hydrate dissociation, and fluid seepage in slope instability and failures?

- How rapidly can gas hydrate or other hydrocarbon reservoirs release large amounts of carbon into the atmosphere to potentially influence global climate or regional safety?

- Are there unidentified offshore areas of important seismic activity, active faults, plate separations, and plate subunits?

- What are the feedbacks between deformation, volcanism, seismic, and hydrothermal activity? 
- What are the physical and chemical fluxes at hydrothermal vents and other regions of seabed fluid and chemical energy flow?

- What are the rates of abiogenic hydrogen and light hydrocarbon production from ultramafic outcrops found at mid-ocean ridges?

- What are the dynamics of mineral resource formation related to hydrothermal venting at mid-ocean ridges?

Questions addressable with additional data and contextual information:

- To what extent do seabed processes influence ocean circulation, seawater chemical composition, biogeochemistry, and marine ecology?

- How does the presence of fluid within submarine faults change their dynamics relative to terrestrial fault zones?

- How might any changes in terrestrial hydrology lead to changes in marine sediment transport and deposition?

\subsection{Physical Oceanography}

\subsubsection{Ocean Warming}

One of the most pressing issues in ocean science today is assessing the impacts of global change on the marine environment, which will likely be long lasting (IPCC 2007a, Doney and Schimel 2007). Significant shifts in ocean heat (Levitus et al. 2000, Barnett et al. 2005, Palmer et al. 2007) and freshwater (Curry and Mauritzen 2005, Boyer et al. 2007) content are already apparent. Mediterranean Intermediate Water (MIW) entering the North Atlantic is warming and becoming more saline (Millot et al. 2006). Continued warming is anticipated to increase stratification in large areas of the ocean including the North Atlantic (Bopp et al. 2005, Marzeion et al. 2010). Related changes to heat content, wind stress, and circulation across European seas are also likely with cascading impacts into biogeochemistry and ecology.

Reduction of ice cover in the Arctic Ocean is occurring and expected to continue with high certainty (IPCC 2007a). Major associated changes in the hydrographic structure of the Arctic waters are expected. Melting sea ice and glaciers can lead to freshwater anomalies, changes in surface-ocean currents, positive feedback between changes in albedo and warming, and destabilisation of gas-hydrates in marine sediments. Changes in physical and biogeochemical conditions are already evident (Soltwedel et al. 2005, Hoste et al. 2007, Westbrook et al. 2009), but current estimates on the ultimate impacts have relatively low certainty (IPCC 2007a, MCCIP 2010).

\subsubsection{Wind-Driven Circulation}

Upper ocean momentum, heat and freshwater fluxes drive ocean transport and stratification (mixed layer dynamics) which in turn controls the interior ocean supply of substances as carbon dioxide, methane, oxygen, and nutrients. These processes are crucial for marine ecosystems functioning (Woods 1985, Joyce et al. 2000, Fasham 2003, Sarmiento and Gruber 2006, Våge, et al. 2009). Observing upper ocean transport and properties underpin assessing the role of the ocean in the climate system and understanding the oceans ecosystem function with relevance from sub-millimetre to basin scale. Winds in the North Atlantic affect circulation to depths of 1000 meters or more with substantial seasonal and interannual variability (Siegel et al. 2002, Palter et al. 2005). Oceanic flow is turbulent and as such the "mean flow" is masked by, sometimes long life, mesoscale and submesoscale $(<10 \mathrm{~km})$ eddies with local dynamics that generate a significant feedback on marine ecosystems (Puillat et al. 2002, Taupier-Letage et al. 2003). 
Wind-driven circulation is sensitive to climate variation. The North Atlantic Oscillation (NAO) dominates interannual climate variation around Europe and tends to bring changes in position and intensity of the North Atlantic atmospheric jet stream which in turn is associated with changes in winds, cloudiness, storms, precipitation, and heat flux (Hurrell 1995, Rodwell et al. 1999, Visbeck et al. 2001, Hurrell et al. 2003) and the functioning of the marine ecosystem (Greene et al. 2003, Sarmiento et al. 2004, Smith et al. 2006, Henson et al. 2009). Decadal scale shifts in North Atlantic surface currents suggest that warmer subtropical waters are increasingly moving northward (Hakkinen and Rhines 2009). The degree to which interannual to decadal climate variability and NAO affects seasonal cycles is not yet clear.

\subsubsection{Deep-Ocean Circulation}

The North Atlantic hosts the major deep convection regions of the northern hemisphere. In particular the formation and spreading of North Atlantic Deep Water (NADW) is of crucial importance for the stability of the meridional overturning circulation (MOC) and global climate. Variations in convection depth and water mass characteristics in the deep water formation regions have been observed (Pickart et al. 2003, Karstensen et al. 2005, Avsic et al. 2007, Sarafanov et al. 2008). Evidence for deep propagation of warming has been reported to at least $2000 \mathrm{~m}$ depth in the Atlantic Ocean (Fig. 6 and 7, Østerhus and Gammelsrød 1999, Dickson and Østerhus 2007, Johnson and Doney 2006, Zenk and Morozov 2007) and worldwide (Johnson and Doney 2006, Fukasawa et al. 2004, Kawano et al. 2006, Johnson et al. 2007, 2008). Deep-ocean ventilation is influenced by surface momentum and heat flux variability and linked to the North Atlantic Oscillation (NAO) variability (Dickson et al., 2002; Sarafanov, 2009). Also more local phenomena, such as ice extent (Våge, et al. 2009), and local heat and momentum fluxes (Pickart et al. 2003) control deep-water formation and circulation (Cunningham et al. 2007).

Clarifying what controls MOC variability is fundamental to assessing climate change impacts. A rapid decrease in the poleward transport of warm surface water in the North Atlantic could have devastating impacts on European climate with substantial regional cooling (Hansen et al. 2001, Vellinga and Wood 2002, Hansen et al. 2004, Hátun et al. 2005, IPCC 2007a), as well as changes in sea level (Yin et al. 2009). Large seasonal variability requires long-term and basin wide monitoring of MOC to detect any possible trend, as for example with the $26^{\circ} \mathrm{N}$ RAPID array (Cunningham et al. 2007, Kanzow et al. 2007, 2008). The confidence with which future projections on this important heat transport mechanism can be made, though, remains relatively low (IPCC 2007a, Kuhlbrodt et al. 2007, MCCIP 2010, Rhines et al. 2008, Stott et al. 2008) and observational evidence is required.

The complex interplay of wind and buoyancy-driven circulation and the MOC makes quantifying the importance of changes in water density, wind, and mixing challenging (Toggweiler and Samuels 1995, Jayne and Marotzke 2001, Talley 2003, Sarmiento et al. 2004, Boccaletti et al. 2005, Rhines 2006, Sarmiento and Gruber 2006, Killworth 2008, Rhines et al. 2008, Grist et al. 2009, Josey et al. 2009). Positive phases of the NAO, for instance, have been shown to be related to greater MOC over interannual to decadal timescales (Eden and Greatbatch 2003). A study forced by IPPC climate scenario A2 suggests that Mediterranean thermohaline circulation (MTHC) is also susceptible to long-term shifts in climate (Somot et al. 2006). Transient climate forcing, wind-driven and deep-water circulation can relate to planetary wave motions, manifested as slow moving surface and internal waves. These waves have lengths of hundreds to thousands of kilometres, can take months or years to cross an ocean basin, and have been related to NAO and MOC variation (Cromwell 2006, Hirschi et al. 2007).

\subsubsection{Benthic-Water Column Interactions}


Direct current measurements are rare and very few include seabed boundary conditions. The seafloor acts as a boundary and how water adjacent to the seafloor interacts with the rest of the ocean is poorly known. Near-bottom flow often driven by tides and density gradients can be complex. Interaction with topography as seamounts, ridges, and sills (Vergnaudgrazzini et al. 1989, Polzin et al. 1997, Munk and Wunsch 1998, Bashmachniko et al. 2004, Lauderdale et al. 2008, Dickson et al. 2008, Fer et al. 2010) create complex flow patterns that can be an important supply pathway for deep sea ecosystems (Davies et al. 2009)

Sediment laden runoff, dense shelf water, and entrained organic matter can cascade down slopes and become focused in canyons (Canals et al. 2006, Arzola et al. 2008, Canals et al. 2009, Lastras et al. 2009). This process has been observed in several areas around European seas, such as the Gulf of Lion, where changes in the North Atlantic Oscillation have had documented influences on organic carbon transport and a deep-sea fishery (Canals et al. 2006, Company et al., 2008, Maynou, 2008, Canals et al. 2009). Combined bathymetry and measurement of time-variant water flow and character has begun to describe this sequence of processes in substantially greater detail (e.g. Borenäs and Lundberg 2004, St. Laurent and Thurnherr 2007). The way in which the slow moving planetary waves interact with the bottom is not well described and long-term observations of wave oscillation are needed (Lecointre et al. 2008). The potential for long-term monitoring of such interactions is great with current observatory systems able to discriminate between various water masses by their various chemical and physical properties (Etiope et al. 2006).

\subsubsection{Marine Forecasting}

The socioeconomic interest in maritime safety in relation to transportation, pollution, search and rescue, and minimising consequences of natural hazards all require observations of ocean physics. At the OceanObs'09 conference there was extraordinary consensus that data from the deep ocean including from fixed points and moorings are among the greatest observational needs remaining (Dushaw et al. 2010, Garzoli et al. 2010, Hurrell et al. 2010, Lampitt et al. 2010, Rintoul et al. 2010, Trenberth et al. 2010). Forecast quality relies on the observations used to constrain models. Satellite retrievals provide as suite of important ocean and atmosphere input data to initialise the ocean surface. About 3000 Argo profiling floats provides in situ temperature and salinity observations to estimate the heat and freshwater variability in the upper $2000 \mathrm{~m}$ of the oceans every 10 days (Roemmich and Owens 2000). Upper ocean moored arrays in the tropical oceans, such as the Tropical Atmosphere Ocean (TAO) array in the equatorial Pacific Ocean (McPhaden and Picaut 1990) or the "Prediction and Research Moored Array in the Atlantic" (PIRATA, Boulres et a. 2008) have been found crucial for ocean forecasting Recent observing system evaluation has shown that both drifting floats and moorings contribute important forecast skill (e.g. Balmaseda and Anderson 2009).

Observatory systems that can simultaneously collect temperature and salinity for the full ocean depth, as well as collect related data such as currents, biogeochemical and ecological quantities, and physical samples are an important tool alongside others such as drifting floats. Long time series of data are of tremendous use when it comes to the validation of model results. Timely ocean physics data is important for monitoring and predicting of pollution in areas of maritime traffic (e.g., the Sea of Marmara, Alboran Sea, Bay of Biscay, or Strait of Gibraltar) where accidents and resulting pollution of oil and hazardous substances occur, such as the sinking of the oil tanker Prestige.

\section{Key questions in physical dynamics and impacts from anthropogenic change:}

Questions addressable with observatory systems: 
- How does ocean heat and freshwater content change over time and how might it impact sea level?

- How rapidly do natural and anthropogenic changes in surface ocean conditions influence deep-sea water masses?

- What are the possible impacts of shifts in deep-water mass character?

- How will projected changes in the extent of Arctic sea ice, or ocean circulation influence regional and global climate, European or global ocean circulation, and biogeochemistry?

- What is the influence of climate variability on upper-ocean circulation and nutrient supply and how might anthropogenic change alter that circulation?

- How do waters within and above the benthic boundary layer interact?

- How do bathymetric features like canyons, valleys, and seamounts influence current directions and speeds and mixing from tidal scales to planetary wave motions?

Questions addressable with additional data and contextual information:

- How stable is deep-ocean circulation and mixing and what controls its variability?

- How can better understanding of slow moving planetary waves be used to clarify the often time-lagged connections between climate and oceanographic processes?

- How can eddies, fronts, and other smaller-scale features be better resolved and included in larger scale assessments?

- What is the importance of precipitation, river run-off, storms, tides and internal waves and other circulation features in resuspension and transport of sediment and its biogeochemical constituents?

- How do regional and local circulation processes interact with global climate variation?

- How does the sparseness of data below $2000 \mathrm{~m}$ depth influence current ocean modelling estimates?

\subsection{Biogeochemistry}

\subsubsection{Solubility Pump and Ocean Acidification}

About one third of anthropogenic carbon dioxide emitted into the atmosphere is thought to be taken up by the oceans through chemical and biological pathways (Sabine et al. 2004, Canadell et al. 2007) with major uptake in the North Atlantic. The process is driven by the combined effect of solubility differences between the atmosphere and ocean and the movement of dissolved carbon in ocean circulation. Present day increases in atmospheric carbon dioxide are partly being absorbed into the relatively lower partial pressure carbon dioxide surface ocean (Takahashi et al. 2002, 2009). Declining uptake of anthropogenic carbon dioxide by the ocean could increase the proportion that accumulates in the atmosphere. Research has suggested that natural sinks of carbon dioxide are already decreasing their uptake rates (Shuster and Watson 2007).

The solubility pump influences carbonate and $\mathrm{pH}$ dynamics, and absorbed carbon dioxide is then available to phytoplankton and the biological pump. Anthropogenic emissions of carbon dioxide appear to be increasing in rate relative to its oceanic uptake (Bindoff et al. 2007). Current techniques measuring carbon uptake in the ocean and related quantities, though, have an inadequate sensitivity to temporal variations (Gruber et al. 2009).

Increased carbon dioxide flux into the ocean is already leading to global secular acidification (Fig.8, Feely et al. 2004, Orr et al. 2005, Raven et al. 2005, Fabry et al. 2008, Feely et al. 2008). Ocean acidification is expected to continue for centuries and is a well constrained process in a variety of model scenarios, but the impacts from lowering $\mathrm{pH}$ are 
much less clear (IPCC 2007a, Zachos et al. 2008, Zeebe et al. 2008). Many marine organisms including calcifying primary producers, molluscs, and corals could be impacted (Orr et al. 2005, Hoegh-Guldberg et al. 2007, Tyrrell 2008). The depths at which calcium carbonate (calcite and aragonite) dissolve may change, as might the burial rates for calcium carbonate (Tyrrell 2008). The ability of organisms to calcify and the bioavailability of trace metals may deminish (Tyrrell 2008, Raven et al. 2005). Acidification is also increasing sound propagation (Hester et al. 2008) with unknown consequences for mammals.

The potential for unforeseen feedbacks in biological responses to acidification is considerable. Several experimental studies have found detrimental effects of increased acidity on calcification in coccolithophores (Riebesell et al. 2000, Zondervan et al. 2001, 2002, Herfort et al. 2004, Delille et al. 2005, Engel et al. 2005, Trimborn et al. 2007), but conflicting outcomes have also been found (Langer et al. 2006, Iglesias-Rodriguez et al. 2008). Deepocean $\mathrm{pH}$ may change at depth specific rates (Dore et al. 2003). Modelling work has found that it was not yet possible to forecast calcification-related trends conclusively because of the range in suggested possibilities (e.g. Ilyina et al. 2009).

Laboratory based experiments to discern potential impacts of changing $\mathrm{pH}$ conditions typically need in situ verification because $\mathrm{pH}$ influences many reactions. Time-series data on changes in acidification dynamics are rare and fewer still directly examine $\mathrm{pH}$ from decadal to seasonal scales. Results from the European Project on OCean Acidification (EPOCA) programme already suggest that comparable results in a broad spatiotemporal context are needed to foster more conclusive forecasts.

\subsubsection{Biological Pump}

Surface phytoplankton take up inorganic nitrogen, phosphate, silicate, and carbon dioxide during photosynthesis and a fraction of the resulting particulate matter sinks into the ocean depths as phytoplankton, fecal pellets, and other detritus forming the biological pump (Fig. 2, Volk and Hoffert 1985, Ducklow et al. 2001, Buessler et al. 2007). Ocean currents and nutrient supply are often tightly coupled to phytoplankton primary production (Fig. 9). Winds drive coastal and open-ocean upwelling which tend to bring nutrient rich water to the surface and enhances productivity with documented variations through decadal scales (e.g. Rykaczewski and Checkley 2008). Interannual variations in production have been associated with the depth of winter mixing (e.g. Somavilla et al. 2009). Seasonal drawdown of carbon dioxide in the North Atlantic has been linked to the biological pump (Körtzinger et al 2008).

Increasingly complex ocean movements further complicate estimation of pump dynamics. Eddies like those that spin off of the Gulf Stream in the North Atlantic are important in influencing plankton blooms as these eddies change local-regional circulation and nutrient availability (Taupier-Letage et al. 2003, McGillicuddy et al. 2007, Bashmachnikov et al. 2009, Smythe-Wright et al. 2010). The effects of large planetary wave motions and NAO variation are linked to chlorophyll concentrations (Mete Uz et al. 2001, Henson et al. 2009). A slowing of the MOC may slow nutrient replenishment resulting in reduced carbon dioxide uptake with a positive feedback to raising carbon dioxide accumulation rates in the atmosphere (Zickfeld et al. 2008).

Nitrogen is the most limiting nutrient in European seas with silicon, phosphorus, and iron also being important. Current methods cannot balance nutrient sources and losses and the spatiotemporal importance of specific nutrients continues to be redefined. Over the past few thousand years it has been suggested that nitrogen budgets have oscillated between net surpluses and deficits forced by climate (Altabet 2007). The supply of nutrient rich water from deeper waters can influence carbon dioxide uptake, even when surface nutrient concentrations show no synoptic variation (e.g. Marinov et al. 2008). Approximately $10 \%$ of the oceans ability to absorb anthropogenic carbon dioxide may be facilitated by atmospheric 
nitrogen deposition (Duce et al. 2008). Nitrogen fixation by diazotrophic phytoplankton, like cyanobacteria, facilitates production in areas of low nitrogen (Capone et al. 1997, Falkowski et al. 1998), and may account for about half of nitrate use (Yool et al. 2007). Model simulations suggest, though, that such biological fixation may not be as dominant in the North Atlantic as in the Equatorial Pacific (Deutsch et al. 2007).

Diatoms depend on silicate to form their frustules and are often an important part of carbon export to deeper depths (e.g. Allen et al. 2005, Henson et al. 2006a). Seasonal blooms of diatoms may account for $65 \%$ of exported production in the Irminger Basin, but typically consume silica during spring blooms and subsequently decline in abundance relative to other phytoplankton (Henson et al. 2006a). Fronts and eddies that continue to provide new silicate through mesoscale circulation can, however, prolong diatom blooms and export (Allen et al. 2005, Benitez-Nelson et al. 2007).

Phosphorous can limit primary productivity and microbial production in the eastern Mediterranean Sea (Krom et al. 1991, 2010). Coccolithophores, Trichodesmium, and Synechococcus appear to be sensitive to phosphorus (Vaulot et al. 1996, Lessard et al. 2005, Dyhruman et al. 2006). Nitrogen and phosphorus could be important for heterotrophic bacteria, even when carbon substrates are available and thus may have competitive interactions with phytoplankton (Mills et al. 2008), and phosphorus and iron could also be important co-limiters of nitrogen fixing phytoplankton (Mills et al. 2004, Arrigo 2005, Moore et al. 2008, Bucciarelli et al. 2010).

Variation in dust inputs primarily from the Saharan and Sahel desert regions (Duce and Tindale 1991, Stuut et al. 2005) add iron and other limiting nutrients (Martin and Fitzwater 1988, Boyd et al. 2007) and influence iron binding ligands in surface waters within about one week (Jickells et al. 2005, Rijkenberg et al. 2008). Up to one third of global dust inputs may occur through this route (Jickells and Spokes 2001). Transient iron limiting conditions have been found in the North Atlantic (Nielsdóttir et al. 2009). More aerosols, though, may not equate to greater productivity because of taxon-specific impacts of aerosol inputs including dust (Payton et al. 2009). Variation in the NAO has been linked to deposition of iron and aluminium in the North Atlantic, but these links remain to be characterised in detail (Tain et al. 2008). The source of aerosol iron can affect its solubility in seawater and thus influence nutrient limitation (Sedwick et al. 2007). Hydrothermal vents may supply 12$22 \%$ of the global dissolved iron in deep waters (Bennett et al. 2008, Tagliabue et al. 2010). Proposals to augment the ability of the ocean to store carbon through ocean iron enrichment or other fertilizers rely on an inadequate understanding of the effectiveness, impacts, and potential feedbacks from such enrichments (Boyd et al. 2007, Buesseler et al. 2008, Lampitt et al. 2008, Shepherd 2009, Yool et al. 2009).

Production and export flux from the surface have important variations which are often not well accounted for in models (Buesseler et al. 2007). The portion of surface production that is transferred to the deep sea has been hypothesised to be related to surface temperature, mineral and polymer content, and zooplankton. Greater recycling of material may occur at higher temperatures in the euphotic zone resulting in proportionally less export (Laws 2004). The mineral content and overall character of sinking phytoplankton is further thought to be important because denser and more protected material is more efficiently transported to deeper depths (Armstrong et al. 2002, Burd and Jackson 2002). The presence of transparent exopolymeric particles (TEP) has been shown to be related to aggregation and sinking rates (Alldredge et al. 1993). Increasing carbon dioxide and ocean acidity could have important implications on sinking rates modulated by TEP (Mari 2008) and mineral content. Zooplankton can consume and modify even smaller pico-phytoplankton into fecal pellets with faster sinking rates (e.g. Richardson and Jackson 2007). 


\subsubsection{Continental Shelf Pump}

Continental shelves are highly productive environments and some portion of the carbon taken up by solubility and biological pumps on the shelf ultimately is exported laterally into deeper waters where it can become sequestered for decades or more (e.g. Bauer and Druffel 1998). The mechanisms and magnitudes of these transfers are still under debate, but could represent about 25\% of the total carbon uptake of the ocean (Chen and Borges 2009). It is believed that much of the fixed carbon is ultimately remineralised to carbon dioxide on the shelf and is then carried to the shelf break in sub surface currents where it cascades into deeper waters (Fennel and Wilkin 2009, Holt et al. 2009, Huthnance et al. 2009). Because these mechanisms relate to such a large part of the oceanic carbon cycle, conclusively determining continental shelf pump processes and the long-term fate of carbon moving through these mechanisms should improve carbon cycle estimates. Open-ocean observatory systems that integrate with those developing for coastal and shelf research are expected to be able to further characterise the timing, intensity, and fate of pumping that is transporting carbon and nutrients across these ocean regions.

\subsubsection{Deep-Ocean Biogeochemical Fluxes}

Evaluating surface and deep-sea variations in fluxes synoptically connects the shortterm and long-term capability of the ocean to take up and store carbon. Sinking organic carbon and other elements provide the primary food supply for deeper dwelling organisms. Organisms respire or otherwise transform the sinking material resulting in the gradual breakdown of most organic matter into its constituent compounds, a process known as remineralisation (Deuser and Ross 1980, Pace et al. 1987, Pfannkuche et al. 1999, Smith and Kaufmann 1999, Lutz et al. 2002, Ståhl et al. 2004). When oxygen utilisation rates exceed the long-term replenishment of oxygen from surface waters oxygen minimum zones (OMZs) can develop between 100 and 900 m depth (Karstensen et al. 2008, Stramma et al. 2008). The combined effects of increasing carbon dioxide and decreasing oxygen could lead to greater negative impacts on organism respiration than from oxygen decline alone (Brewer and Peltzer 2009), especially in OMZ areas such as east of Cape Verde in the North Atlantic.

Long-term Time-series data from abyssal depths comes from only a few locations, so addressing various areas of uncertainty simultaneously has been difficult (Lutz et al. 2002, Honjo et al. 2008, Glover et al. 2010), but some surprising results have been found. Variations like the NAO and ENSO have far reaching affects that include changes in gas and heat flux, ocean circulation, primary productivity, and the efficiency with which surface production is transferred to support deep-sea life (e.g. Cayan 1992, Wade et al. 1997, Ruhl and Smith 2004, Behrenfeld et al. 2006, Smith et al. 2006, Thomas et al. 2008, Henson et al. 2009, Billett et al. 2010, Lampitt et al. 2010). Year to year variability in the quantity and quality of particulate organic carbon (POC) fluxes to the abyssal seafloor can be as much as an order of magnitude in the Northeast Atlantic (Hartman et al. 2010, Lampitt et al. 2010). The efficiency of the transfer of carbon from surface waters to the deep sea is known to vary in space and time (Lampitt and Antia, 1997, Lutz et al. 2002, Laws 2004, Dore et al. 2003, Hartman et al. 2010, Lampitt et al. 2010).

There are major unexplained imbalances between the estimates of downward flux of organic matter and the rates of organic matter remineralisation at the seafloor (Smith and Kaufmann 1999, Smith et al. 2001, Smith et al. 2008a). These imbalances could be a result of unobserved lateral transport of organic matter or insufficient spatial or temporal resolution of measurements. Lateral transport can result, in part, from organic matter transported off continental shelves down slopes or through bights and canyons (Canals et al. 2006, Test et al. 2008). Some model scenarios show that shelves may be the source for up to almost half of the organic carbon that accumulates in deep-sea sediments (Dunne et al. 2007). Water near the 
seabed often forms a benthic boundary layer containing resuspended material tens of meters or more above the seafloor at abyssal depths (Baldwin et al. 1998).

Because circulation between the boundary layer and adjacent and overlying water is so poorly known the degree to which the entrained material can be transported is unknown further confounding the above mentioned lack of knowledge in organic matter transport in the deep sea. Current sedimentation traps may under sample sinking POC, especially aggregates that contain important quantities of sinking carbon (Baldwin et al. 1998, Robison et al. 2005, Smith et al. 2008a). A 17-year study in the Northeast Pacific found that even when accounting for presumed under sampling, perceived deficits in carbon inputs often remained (Smith et al. 2008a).

Assessing connections between the upper ocean and deep seafloor need improved estimates of when and where particles reaching deep-sea habitats originated, as well as what controls seafloor settling. Organic material reaching any particular point in the deep sea is generally believed to come from a funnel volume overlying the destination (Siegal and Deuser 1997). Long-term sedimentation trap records in conjunction with contemporary water velocity meters and satellite estimated surface conditions can be used to back track the potential origins of particles (Smith et al. 2006, Siegel et al. 2008, Hartment et al. 2010), but these techniques have yet to be widely applied.

\section{Key questions in biogeochemical dynamics and impacts from anthropogenic change:}

Questions addressable with observatory systems:

- What are oceanic carbon and greenhouse gas uptake and storage dynamics and how might anthropogenic change alter the efficiency of the biological pump?

- What aspects of marine biogeochemical cycling will be most sensitive to climate change?

- What are the biogeochemical implications of oxygen minimum zone intensification including changes in oxidation potential and hypoxia?

- Are observed deficits in organic carbon input vs. respiration linked to timescales of observation, basin selectivity, or to lateral transports of organic particles?

- What will the important feedbacks of potential ecological change be on biogeochemical cycles and how rapidly might they occur?

Questions addressable with additional data and contextual information:

- How will changes in atmospheric dust deposition rates influence ocean biogeochemistry?

- What quantities of sediment, nutrients, and/or organic material are transported in deep currents and turbidity flows and how does this transport vary?

- To what degree are terrestrial, coastal and slope regions influencing open-ocean biogeochemical quantities including potentially harmful contaminants?

- What will the intensity and distribution of ocean acidification be, and how will changes in acidity affect the bioavailability of trace metals important to primary production, marine life, and biogeochemical cycling?

\subsection{Marine Ecology}

\subsubsection{Climate Forcing of Ecosystems}

Evaluating the sensitivity of ecosystem function to anthropogenic change is a major marine science challenge of the coming decades (Sutherland et al. 2006). Life exists within environmental and resource constraints, most of which are hardly known. Marine organisms are influenced by their environment, and can exert strong feedbacks to their physical and chemical surroundings. Ecological change due to global warming and carbon dioxide 
accumulation in the ocean could have numerous repercussions when compared to terrestrial systems (Richardson 2008). Yet datasets capable of observing climatically-driven changes in marine biology are rare with very few capable of discerning between interannual and decadal variations and secular change (Rosenweig et al. 2008). The need to quantitatively assess the role of ecosystems as anthropogenic change progresses is driving ecosystem function to gain importance in ecology.

Manifestations of climate influence include synchronised variations between neighbouring local areas, temporal correlations between climate and ecological quantities, time lagged correlations, phenological shifts, and match-mismatches between co-dependent phenomena (Moran 1953, Stenseth et al. 2002, Royama, 2005). Temporal phenomena have spatial analogues where match-mismatchs could be a result of shifting distributions. When key elements of food webs are destabilised, effects can cascade to other food web elements, trophic levels, and ecosystem functions.

Climate can influence primary production from daily to decadal scales and longer (Kahru and Mitchell 2002, Behrenfeld et al. 2006, Heath and Beare 2008). Contemporary warming has been implicated in pelagic community change (e.g. Field et al. 2006) and an overall decline in the abundance of primary producers, including the north Atlantic (Boyce et al. 2010). Climate-driven changes in the nature of primary production can have cascading impacts (McGowan et al. 1998, Parsons and Lear 2001, Chavez et al. 2003, Attrill and Power 2004, Green and Pershing 2007, Rykaczewski and Checkley 2007). North Atlantic storm frequency may delay stratification leading to match-mismatches between light and nutrients thus diminishing production (Henson et al. 2006b). Mis-matches can then cascade to zooplankton and fisheries (Edwards and Richardson 2004, Richardson and Schoeman 2004, Piontkovski et al. 2006, Koeller et al. 2009). Connections between climate and ecological systems can be subtle and complex, but result in pervasive responses to abyssal depths (e.g. Billett et al. 2001, Ruhl et al. 2008).

\subsubsection{Molecules to Microbes}

Research in microbial oceanography regularly reveals fundamental knowledge. Marine viruses have been found to be very abundant with cell lyses influencing biogeochemistry (Azam et al. 1983, Fuhrman 1999, Azam and Long 2001) potentially limiting prokaryotic production in the deep sea (Danovaro et al. 2008a). Extracellular DNA in marine sediments, believed to be remnants of surface production, may account for $14-21 \%$ of phosphorus cycling in the deep ocean (Dell'Anno and Danovaro 2005) and harbour gene pools (Rohwer and Thurber 2009). The extent to which viruses influence the deep sea, though, remains to be confirmed (Williamson et al. 2008). The balance of production and respiration in the sea has also been questioned when microbial rates are accounted (del Giorgio et al. 1997). Evidence from Argo floats suggests that deficits were perceived because oxygen production is more episodic in space and time than previously thought (Riser and Johnson 2008).

Consensus on net respiration has, however, yet to be achieved. Dissolved organic carbon (DOC) is abundant in the ocean and likely accounts for some of the observed discrepancies between observed sinking POC fluxes and carbon demand (Burd et al. 2010). DOC, which is not accounted for in sinking POC flux estimates, is modified by microbes throughout the water column into relatively refractory forms through processes including respiration. New findings about the prevalence of chromophoric dissolved organic matter (CDOM) in surface waters require further attention partly because its presence is important in determining productivity from satellite ocean colour data (Nelson et al. 2007).

New natural products and drug discovery efforts frequently utilise specimens collected from a variety of unusual habitats (Fenical 1982). Specimens collected during observatory 
operation in extreme environments have potential for cancer, antibacterial, and enzymes. A common challenge in natural product exploitation is that once key compounds are identified, they may be difficult to produce (Baran et al. 2007). Linking sample collecting to comprehensive ecological observations should improve capability for producing valuable natural products commercially.

In situ metagenomics, or the links between genes and their environment and function, will likely reveal important metabolic aspects not otherwise discernable because many microbial fauna are not yet cultured in laboratory settings. It is now possible to collect molecular probe data that is processed in situ, in real time (Paul et al. 2007). In situ microbial community data will increase ability to discern if microbes have similar tendencies of community assembly and structuring found elsewhere in ecology (Hewson et al. 2006, Ruan et al. 2006, Horner-Devine et al. 2007, Fuhrman and Steele 2008, Fuhrman et al. 2008). Metagenomic sequencing and community fingerprinting are poised to improve understanding of microbial oceanography (Sogin et al. 2006, Karl 2007, Bowler et al. 2009, DeLong 2009, Fuhrman 2009). Within Europe coordination between Marine Genomics Europe, and LIFEWATCH, the European infrastructure for biodiversity data and observatories, are preparing microbial observatory users to make needed advances.

\subsubsection{Fisheries}

Sustainable fisheries management depends on informative estimations of nutrients and production conveyance to higher trophic levels of fished stocks. Partitioning climatic drivers from fishing pressure has major implications for managing sustainable fisheries into the future because of the growing potential for errors in asserting the causes of variations. Evidence of climate influence on fisheries is extensive in the North Atlantic (Beaugrand et al. 2003, Erzini 2005, Santos et al. 2005, Stige et al. 2006), Mediterranian (Company et al. 2008, Maynou 2008) and Pacific (Catchpole and Auliciens 1999, Hare and Mantua 2000, Chavez et al. 2003, Rykaczewski and Checkley 2007). The effects of fisheries in surface waters could extend thousands of meters below the surface (Drazen et al. 2008, Bailey et al. 2009). Fished populations are thought to be especially susceptible to climate related change because of cascading match-mismatch impacts (e.g. Edwards and Richardson 2004) and selective pressure on age and size within the populations and major climate-fishery links have already been observed (Hsieh and Ohman 2006, Brander 2007, Anderson et al. 2008, Hsieh et al. 2008, Hsieh et al. 2009). Fish have also been suggested to play an important role in controlling ocean alkalinity (Wilson et al. 2009), a process not fully considered in ocean models. In most cases, though, further investigation into the underlying mechanisms of fish stock dynamics is needed for direct use in resource management (Erzini 2005).

\subsubsection{Bioacoustics}

The oceans are filled with natural and biological sounds, although many artificial sources have contributed increasingly to its overall noise budget (Fig. 10). The influence of anthropogenic noise on marine life constitutes an issue of considerable interest both to the scientific community and public. Artificial sources can interfere with the natural use of sounds by marine organisms and may constitute a physical threat for the species exposed (Richardson et al. 1995, Engås et al. 1996, Gordon et al. 1998, McCauley et al. 2000, Guerra 2004). The quantity of anthropogenic noise in the ocean is increasing along with greater human marine activity (Hildebrand 2009). A key question is whether the human-generated sounds affect the ability of marine animals to pursue their normal activities, reproduce, and maintain healthy populations. The sources of human-related noise include intentionally produced noise from navigation and surveying to unintentionally generated noise, such as commercial shipping, offshore construction, and recreational boating (Hildebrand 2009). 
Sound in the ocean is diverse and its detection appears to have evolutionary and ecological roles in the lives of many marine mammals, fish, and invertebrates (André and Nachtigall 2007). Unintentional sounds include, for example, those produced by schools of fish swimming through the ocean or release of air by large groups of fish as they adjust their buoyancy. Intentional sounds, including whale songs, dolphin clicks, and fish vocalisations, are believed to be produced in various species for communication, echolocation, and perhaps even acoustic imaging of the environment (Tyack and Clark 2000, Würsig and Richardson 2002). Current data on the impact of anthropogenic sounds on marine mammals and the marine ecosystem is sufficiently great to warrant further consideration by both the scientific community and the public (Hildebrand 2009, Jensen et al. 2009, Di Iorio and Clark 2010).

Long-term quantification of sounds is needed to establish a database for classification of sounds, monitoring of marine organisms and population dynamics, and ultimately assessments of anthropogenic effects on marine organisms. Passive hydrophones are a simple and powerful tool for biological sensing in ocean observatories and can evaluate the human and natural contributions to marine noise and describe the long-term trends in ambient noise levels. As gaps in marine acoustic research are filled, they will be used in the development of a model of ocean noise that incorporates temporal, spatial, and frequency-dependent variables to better understand recorded signals (e.g. Clark et al. 2009).

\subsubsection{Export Flux Dependent Ecosystems}

Changes in primary production and the quantity and quality of sinking organic matter have clear influences on the animals that depend on this food supply, but evidence for these connections and the processes leading to any observed changes in the deep ocean comes from only a few locations. If projected increases in stratification due to global warming occur, then smaller and more nutrient efficient phytoplankton species will likely be favoured (Bopp et al. 2005). Change in phytoplankton community structure could alter the quantity and quality of flux material to abyssal depths (Buesseler et al. 2007).

In addition to the makeup of surface water communities, the inhabitants of the deep sea, the world's largest biome, have an important role in determining the depths to which carbon is exported (Robinson et al. 2010). Pelagic zooplankton, like filter feeding salps and appendicularians, can change in abundance in relative synchrony with production at the surface (Robison et al. 2005, Smith et al. 2008a). These zooplankton consume substantial amounts of organic matter and reform it into dense faecal pellets and organism fragments that are transferred relatively quickly to deeper depths as sinking POC (Pfannkuche and Lochte 1993, Robison et al. 2005, Richardson and Jackson 2007, Smith et al. 2008a, Sutherland et al. 2010, Wilson and Steinberg 2010). The lack of data from midwater depths severely limits the ability of researchers to quantify the importance of microbes and zooplankton in determining the efficiency of the biological pump (Robinson et al. 2010).

Deep-sea communities are food limited and respond to changes in their food supply, sinking POC, over timescales that are not very different from those of shallow water or terrestrial systems. Spatial studies have repeatedly found that higher abundances of benthic organisms from bacteria to megafauna are typically found beneath areas of higher productivity (Rowe et al. 1982, Cosson et al. 1997, Smith et al. 1997, Levin et al. 2001, Gambi and Danovaro 2006, Rex et al. 2006, Johnson et al. 2007, Smith et al. 2008b). Timeseries data have confirmed that changes in the flux of POC relate to changes in meiofaunal (Pfannkuche et al. 1999, Galéron et al. 2001, Witte et al. 2003, Danovaro et al. 2004, Danovaro et al. 2008b), macrofaunal (Drazen et al. 1998, Galéron et al. 2001, Smith et al. 2002, Hoste et al. 2007, Ruhl et al. 2008), and megafauna community structure and function (Fig. 11, Billett et al. 2001, Ruhl and Smith 2004, Colaço et al. 2006, Dixon et al. 2006, Ruhl et al. 2008, Colaço et al. 2009, Billett et al. 2010), as well as deep-sea fisheries (Company et 
al. 2008, Maynou 2008, Bailey et al. 2009). Bacterial and meiofauna responses to food inputs were on the order of hours (e.g. Pfannkuche et al. 1999) and megafauna densities and community structure showed significant correlation to food inputs after several months (e.g. Ruhl 2008).

Particulate carbon that sinks to the seabed eventually becomes ingested and remineralised back into the water column, or buried geologically in sediments. Benthic fauna thus influence how much of the organic carbon reaching this system boundary remains in the contemporary marine environment as carbon dioxide, modified organic matter, or is buried. The notions that deep-sea communities respond readily to climate change and that diversity in deep-sea has been related exponentially to ecosystem functions like carbon cycling (Danovaro et al. 2008b) suggest that if large scale changes in food availability occur as predicted (Pierce 2004, Bopp et al. 2005), they could lead to major changes in the benthos and its function. Proposed ocean iron fertilisation efforts, which aim to increase POC fluxes (Boyd et al. 2007, Buesseler et al. 2008, Lampitt et al. 2008), will also likely have a major impact on the deepsea benthos.

Corals in the deep ocean have higher diversity and levels of respiration and thus ecosystem function when compared to surrounding areas (Lavaleye et al. 2009, van Oevelen et al. 2009). They can be important habitat areas for some deep-sea fisheries (Costello et al. 2005, D’Onghia et al. 2010, Althaus et al. 2009). These coral fauna, though, have life-history traits that require longer-term sustained observation in order to evaluate their ecology. Current evidence suggests, though, that cold-water corals may have a relatively narrow range of POC flux tolerance below which they starve and above which they become smothered. There may be sensitivities to temperature and ocean acidification like those found for their shallow water congeners (Grottoli et al. 2006, Roberts et al. 2006, Fine and Tchernov 2007, HoeghGuldberg et al. 2007, Roberts et al. 2009).

Benthic processes influence the waters above and create a benthic boundary layer of water tens of meters or more above the seabed. Seabed modifications of organic matter can result in upward fluxes of buoyant particles that could be as high as two thirds of the downward flux over periods of one to two weeks (Smith et al. 1989). Because this process is not accounted for in current global carbon models, evaluating the degree to which processes occurring within the benthic boundary layer connect to the overlying water should add needed certainty to forecasts of ecological and biogeochemical change. Surface waters may not be well mixed with water at abyssal depths, but variations in surface conditions can influence life in the deep sea within weeks. The current estimate of ocean age below $1500 \mathrm{~m}$ depth for both the Atlantic and Southern Ocean is approximately 300 years (Fig. 14, Matsumoto 2007), which overlaps with the longer-term estimates of climate warming (IPCC 2007a). So even subtle changes in deep-sea ecological function could have a considerable impact on global biogeochemistry, especially if they persist over the centennial scales of climate change predicted.

\subsubsection{Deep Biosphere and Chemosynthetic Ecology}

The persistent discovery of life in environments that were previously thought to be relatively devoid of life continues to redefine the fundamental abundance, distribution, and function of life on Earth. The study of these extreme systems has importance for considering where life might be possible on other worlds. The discovery of chemosynthesis-based communities at the seafloor (e.g. Paull et al. 1985, Van Dover et al. 2002) and microbes in sediments several hundred meters below the seafloor (D’Hondt et al. 2004, Blair et al. 2007, Smith and D'Hondt 2006, Biddle et al. 2008) continue to redefine understanding of life (Fig. 12). Quantifying the diversity of form and metabolic function in these communities continues to be a major research focus with links to geosciences. The breakdown of water from 
background radiation, which releases the electron donor hydrogen, is a recent example of a novel source of energy to maintain microbial life (Blair et al. 2007, Chivian et al. 2008).

Synoptically monitoring these communities along with changes in biogeochemistry, fluid flux rates, and geophysical motions should increase understanding of how chemosynthetically-driven systems utilise reducing compounds like sulphur or methane to provide energy for carbon fixation instead of using light energy. Methanotrophic microbes, for instance, act as an important sink for methane released at the seafloor (Boetius et al. 2000, Boetius and Suess 2004, Niemann et al. 2006a, 2006b, Nuzzo et al. 2008, Lichtschlag et al. 2010). Chemosynthetic habitats can range from superheated waters with chemical concentrations lethal to most life (Van Dover et al. 2002) to more benign areas where methane seeps from sediments and supports life (Paull et al. 1985) often with important dependences on symbiotic relationships (e.g. Robidart et al. 2008). Their isolation allows for highly targeted studies of biogeographic processes (e.g. Gebruk et al. 2000, Bachraty et al. 2009). The presence of certain chemosynthetic dependant fauna can be indicative of the sometimes difficult to observe methane, sulphur, or gas hydrate reserves (Olu-Le Roy et al. 2004, Zitter et al. 2008). The degree to which chemosynthetic systems on the whole also have a dependence on the downflow of oxygen and nutrients from the upper layers of the ocean (Riou et al. 2010, Dixon et al. 2006) also needs clarification. These systems not only create localised communities, but also have poorly defined influences on surrounding habitats including upward fluxes of organic matter (Cowen et al. 2001).

\section{Key questions in marine ecology dynamics and impacts from anthropogenic change:}

\section{Questions addressable with observatory systems:}

- What marine life is influential in biogeochemical cycling and how sensitive are they to climatic and anthropogenic change?

- What are the ecological functions of the recently described diversity and abundance in microbial systems including viruses, archea, bacteria, and protozoa?

- How do community and ecosystem function changes throughout the water column influence biogeochemical fluxes and feedbacks across trophic levels?

- How do variations in environmental conditions and resources interact with resource partitioning, competition, and other factors to drive community change?

- To what extent are changes in productivity, diversity, community structure, and ecosystem function related, and what processes alter or maintain them?

- What is the influence of diversity and habitat structure from deep-sea coral communities and what factors control their growth and abundance?

- What are the distributions and migration patterns for marine mammals and what is the influence of anthropogenic noise and climate change on their ecology?

- How do seismic and other solid earth processes influence benthic and water column ecosystems?

- What are the fluxes of organic matter through chemosynthetic communities?

- What are the impacts of hydrocarbon, mineral and marine natural products exploration and exploitation, and how can they be minimised in future efforts?

Questions addressable with additional data and contextual information:

- How does the abundance and distribution of marine life vary over time and what will the influence of anthropogenic change be?

- What factors control deep-biosphere habitat and community dynamics and how does such life fix carbon and interact with other ocean systems? 
- What is the importance of lateral transport and spatiotemporally aggregated biogeochemical fluxes in meeting observed metabolic demands of communities?

- What are the most influential taxa within various functional groups and which might be used as indicators of community wide change?

- What types of marine life are most sensitive to anthropogenic noise and in what areas could marine noise be particularly harmful?

- How are microbial dynamics, CDOM, and ocean colour related?

\subsection{Transformative Ocean and Earth Science}

Greater focus on socially relevant issues demands a more integrated approach than has been achieved. As more processes are identified and evaluated, the need to compare and understand potential connections and feedbacks between such processes increases. A clear way to bring greater continuity to discerning connections across disciplines, space, and time, is to more fully augment typical research projects with standardised and integrated in situ observations from a network of ocean reference stations. Socioeconomically important topics which cross-cut the above outlined science areas include themes spanning numerous spatial and temporal scales such as:

- Natural and anthropogenic change

- Interactions between ecosystem services, biodiversity, biogeochemistry, physics and climate

- Impacts of habitat destruction and pollution on ecosystems and their services

- Impacts of exploration and extraction of energy, minerals, and living resources

- Geo-hazard early warning capability for earthquakes, tsunamis, and gas hydrate release

- Connecting scientific outcomes to stakeholders and policy makers

There is now growing awareness of connections between climate and open-ocean environments and their importance for society. Developing frameworks for more formalised discussions of how to document and value ecosystem goods and services are making the societal relevance of surface and deep-sea processes clearer (e.g. Nellemann et al. 2008, Grehan et al. 2009). Bioeconomic modelling, for example, has been shown to be a powerful tool, but needs a stronger science basis (Armstrong et al. 2009). Ocean observatories and the consortiums that utilise them are now working to incorporate economic and legal perspectives in conjunction with natural science because together those perspectives inform policy on deep-sea resource use, geo-hazard warning, fisheries, and law of the sea legislation (Grehan et al. 2009). The United Nations Environment Programme (UNEP), HERMES, and the Center for Ocean Solutions have highlighted oceanic and deep-sea ecosystem functions, goods and services, and socioeconomic benefits they provide (Table 1, Nellemann et al. 2008, Center for Ocean Solutions 2009, Grehan et al. 2009).

Great socioeconomic gains are possible through increased understanding of ocean science. Links between research breakthroughs and socioeconomic gain are often complex, but relate to important portions of gross domestic product (GDP). Marine research and development influence extends well beyond marine GDP, especially considering climatic and geo-hazard aspects (Flemming 2007). The GDP attributed to marine research and development is about 1\%, or more, of total marine GDP (Pugh 2008). Further investment in research that can enhance sustainability of marine economic sectors should stabilise or enhance overall GDP. Because most economic cost-benefit models do not capture the potential for environmental information in policy making, cost-benefit models need new science input to accommodate the pervasive influences of ocean processes on GDP. 
It is the societal need to understand connections between ocean processes and society that drive ocean observatory science today. Socioeconomic services can be broken down into supporting (i.e. upstream services), and provisioning, regulating and cultural services that rely on supporting services. In the ocean these range from biogeochemical cycling and habitat structure upstream to natural resources, climate regulation, health and safety and quality of life. The connections between these forcing factors, supporting services, and services are often undefined.

The European Marine Strategy Framework Directive calls for sustainable use of the seas, ecosystem-based management, establishment of environmental status indicators and targets, and a means to evaluate if they are being achieved. The directive stipulates that the related monitoring should examine causes of change, ensure comparability of assessments, and address natural variability. Policies with similar attributes have been developed in many nations worldwide and typically include sustainable use and awareness of change as core principles. The European Commission has funded several programmes with integrating activities for open-ocean research. HERMES, MarBEF NoE, HERMIONE, and CoralFISH are examples of European projects integrating researchers studying ecosystem hotspots and highlighting connections between forcing factors like climate change, ecosystem services, and socioeconomic impacts. Active research using observatories in EuroSITES is providing standardised data capable of bridging various measurement scales across a dispersed network. Future observatory science and technical planning are progressing in ESONET NoE. EMSO is working to create a formal organisation to build and operate a distributed European research infrastructure of fixed point observatories in the open ocean. Ocean observatories can then combine with other infrastructures like satellites, EuroARGO, and the Integrated Carbon Observing System (ICOS) in the European Marine Observation and Data Network (EMODNET).

The greater potential of these systems will be realised when they can be utilised in a global setting. European observatory projects contribute to GEOSS, GMES, and geo-hazard networks and inform work in the IPCC (Intergovernmental Panel on Climate Change), UNEP (United Nations Environment Programme), and OSPAR (the Convention for the Protection of the Marine Environment of the North-East Atlantic). Other ocean observatory developments include NEPTUNE Canada, the US Ocean Observatories Initiative (OOI), the Monterey Accelerated Research System (MARS), the Japanese Dense Ocean Network for Earthquake and Tsunami detection (DONET), the Marine Cable Hosted Observatory (MACHO) offshore Taiwan, and the Deep-ocean Environmental Long-term Observatory System (DELOS) (Table 1; Favali et al. 2010b). Ultimately these programmes can all relate to GEOSS at a global scale. GEOSS may even develop long-term working groups to harmonise best practices, standards and organise global scale analyses from ocean observatory data.

\section{Observatory Design}

\subsection{Observatory Fundamentals}

The most transformative aspect of the observatory design will be its ability to address interdisciplinary objectives simultaneously across scales and relate that information to researchers and hazard managers in a timely manner. Various designs have been under consideration for more than a decade (Thiel et al. 1994, Berta et al. 1995, Rigaud et al. 1998, Beranzoli et al. 2002, Priede et al., 2003, 2005, Blandin and Rolin, 2005, Favali and Beranzoli 2006, Favali et al. 2006a, Frugoni et al. 2006). These tools can be brought to bear in the water-column, on the seafloor, and sub-seafloor depending on the application Ocean observatories can be attached to a cable providing power and data transfer or operate as independent benthic and moored instruments. Furthermore systems may include autonomous 
vehicles that can transfer data or recharge power supplies. Data can also be transmitted through acoustic networks that are connected to a satellite-linked buoy. Mobile systems can be used to expand the spatial extent of a node. Integration of science instrumentation into developing hydrocarbon extraction areas, as done in the DELOS project, is another promising infrastructure development. Observatories are being implemented in a staged manner to first deploy proven technology and incrementally include new technology to meet science objectives. Operation and maintenance is being done primarily by oceanographic marine research facilities.

Requirements for data transmission represent an important factor in observatory design and range from real-time, near real-time, delayed or truncated transmission, to systems where data is only recovered during observatory servicing. The most critical need for realtime data transmission is for time-sensitive geophysical measurements and geo-hazard earlywarning systems. All other applications can rely on near real-time or less frequent feedback, albeit with relatively low data transmission rates. For observatories that are sufficiently close to shore, cables delivering power and communication can be an optimum solution, hence providing energy and real-time data transfer. Two-way communication may also be required to adapt sampling protocol to new conditions, but not necessarily via cable.

The infrastructure designs are being derived from an iterative process that considers the broad science objectives, establishes related requirements, and integrates technical and logistical input. The science objectives that drive ocean observatory development dictate ability to collect data without the presence of a research vessel over a range of timescales up to decades. The modular design must incorporate standardisation and interoperability concepts to improve system functionality, reliability, and comparability of results (Waldmann et al. 2010). It must transmit time-sensitive data sufficiently, and where feasible deliver power, two-way communication and instrument management, and ultimately make data products openly available. Data provenance should be maintained for quality control and crediting to the originator.

\subsection{Principal Observatory Nodes}

The proposed locations capture many facets of geology, biogeochemistry, and ecology of ocean regions around Europe, but they do so across an unprecedented spectrum of variation (Priede et al. 2003, 2005). Previously biogeochemical and other studies have been very limited in the extent to which the observed process rates and relationships could be applied. If variation is only observed over a limited range particular to a single biogeochemical province, those rates and relationships may not be applicable in environmental or resource variations that exceed the site-specific observed variation. The sites span the eight major biogeochemical provinces around Europe including the Boreal Polar (BPLR), Atlantic Arctic (ARCT), Atlantic Subarctic (SARC), the North Atlantic Drift (NADR), Northeast Atlantic Continental Shelf (NECS), North Atlantic Subtropical Gyre East (NASW), and Mediterranean (MEDI) described by Longhurst (2006) (Fig. 3). The sites capitalise on existing programmes which add substantial contextual data, and logistical value. It is envisioned that observatory sites in HERMIONE, EuroSITES, and ESONET will be able to join the formal ocean observatory organisation when basic readiness criteria are met.

The Arctic node is active across the Fram Strait $\left(79^{\circ} \mathrm{N}\right)$ at the southern extent of the BPLR. Work there is focused on activities like evaluating heat and mass transport through the Fram Strait, links between climate and surface ocean processes and deep-sea ecosystems, and methane hydrate dynamics. The HAUSGARTEN observatory has operated at the site since 1999 (Soltwedel et al. 2005) and more recent activity includes the ESONET demonstration mission Arctic Ocean ESONET Mission (AOEM), as well as HERMIONE and HYPOX research. Because the Arctic is believed to be one of the most sensitive areas to anthropogenic 
change, research in this region is very likely to document substantial shifts in physical, biogeochemical, and ecological processes.

The Hakon Mosby Mud Volcano $\left(72^{\circ} \mathrm{N}, 14^{\circ} 44^{\prime} \mathrm{E}\right)$ is a geologically active area situated roughly at the confluence of the SARC and NECS regions at the entrance to the Barents Sea at about $1250 \mathrm{~m}$ depth. Research at the site has found that mud and methane emitted from the seafloor create a complex caldera bathymetry and ecology. Methane has been found to be consumed by the microbial life around the area, but this process is limited by the presence of oxygen and sulphate (Niemann, 2006a). This site has been an area of intermittently active work and ESONET is running a demonstration mission at the site called Long-term Observations On Mud-volcano Eruptions (LOOME).

Meridional overturning and thermohaline circulation are measured at Weather Station Mike $\left(66^{\circ} \mathrm{N}, 2^{\circ} \mathrm{E}\right)$ near the convergence of the ARCT and SARC biogeochemical regions in the southern Norwegian Sea. This site benefits from the use of an existing sub-sea cable and an existing decadal scale data record of currents at the site. Ship-based hydrography surveys to several thousand meters depth have been conducted in this vicinity since the 1950's and produced detailed evidence of secular warming to depths greater than $2000 \mathrm{~m}$ (Fig. 6).

Time series observatories in the centres of deep convection in the Labrador (K1, $56.5^{\circ} \mathrm{N}, 52.6^{\circ} \mathrm{W}$; Avisc et al. 2006) and Central Irminger Sea (CIS; 59. $4^{\circ} \mathrm{N}, 39.4^{\circ} \mathrm{W}$ ) have been operating for more than a decade. These observations are of globalimportance as they provide year-round crucial information on hydrographic properties during active convection (Figure 7) that are not accessible from ship expeditions. CIS is also in EuroSITES network and in the vicinity of one of the US OOI Global Scale Nodes. The co-location of international research effort in this region is expected to bring needed breath to observing capability and collaboration in this globally important area.

The Porcupine Seabight and Porcupine Abyssal Plain (PAP) have been areas of active physical oceanography, biogeochemical, and deep-sea ecological research since the 1980's under programmes such as the international Joint Global Ocean Flux Study (JGOFS) and BENthic biology and Geochemistry of a north-eastern Atlantic abyssal Locality (BENGAL). More recently work at PAP has integrated into the EuroSITES project and is the site of the PAP - Sustained Observatory and the ESONET demonstration mission examining MOdular Deep Ocean Observatory (MODOO) design. The study area is located in the NADR in an area of $4850 \mathrm{~m}$ depth. The Porcupine Seabight and Gollum Channel can have significant movements of flocculent organic material along the seabed (Tudhope and Scoffin 1995). Integration of observing nodes from the upper seabight through Gollum Channel out to PAP could bring needed balance in carbon budgets.

The Mid-Atlantic Ridge near the Azores in the NASW biogeochemical province has been an active site for more than a decade in association with the international InterRidge programme (Fouquet et al. 1995). Work there is centred on the Lucky Strike hydrothermal vent field at 1700 meters depth and includes research on geophysical motion (seismicity and deformation) and the water, heat, and elemental quantities through the vent systems, behaviour of the physical and chemical properties of the fluids, as well as the variations in biogeochemistry, and on the ecological hotspots that occur in the vicinity of the vents (Miranda et al. 2005). Condor seamount offshore of the Azores area has been closed to the fisheries, and observatory studies are being conducted in order to promote a sustainable use of these ecosystems (Giacomello and Menezes, 2009; Morato et al, 2010). The Mid-Atlantic Ridge work has been part of the MarBEF - DEEPSETS, HERMIONE, and Coralfish programmes among others. The area is also the site of another ESONET demonstration mission, Monitoring the Mid-Atlantic Ridge (MoMAR).

Northeast of the Cape Verde islands is the Tropical Eastern North Atlantic Time Series Observatory (TENATSO; $17.4^{\circ} \mathrm{N}, 24.5^{\circ} \mathrm{W}$ ) that consists of a water column observatory 
since 2006 and augmented with regular ship-based biogeochemistry observations. In combination with an atmospheric observatory in the lee of the ocean observatory comprehensive observations of the atmosphere/ocean system are accessible. Scientific motivation of the site includes the impact of iron enrichment through Sarahan dust outbreaks on ocean biogeochemistry and biology as well as observations in the origin region of hurricanes (Rijkenberg et al. 2008, Ye et al. 2009). Data collected at the site contributes to programmes such as the Surface Ocean Lower Atmosphere Study (SOLAS) and EuroSITES.

The European Station for Time-series in the Ocean, Canary Islands (ESTOC; 29.04으, $15.5^{\circ} \mathrm{W}$ ) has been operating since 1994 and focuses on ocean physics and biogeochemistry (Neuer et al. 2007, Troupin et al. 2010). A decadal record of ocean acidification is also available from this site (Santana-Casiano et al. 2007). The site is part of the EuroSITES network and contributes to research on the dynamics of the north Atlantic subtropical gyre in collaboration with researchers working at the Bermuda Atlantic Time-Series site (BATS; Helmke et al. 2010).

The Iberian margin is an area of geophysical activity near the Eurasian and African plate boundary off the Portuguese coast. The study site from 700 to over $4000 \mathrm{~m}$ depth is within the NASW near where Mediterranean Intermediate Water enters the Atlantic and influences meridional overturning circulation. The site has mud volcanoes, pockmarks, mud diapers, carbonate chimneys, hydrocarbon venting, and faulting. This is another area of active research by HERMIONE, as well as NEAREST and NEAMTWS geo-hazard early warning systems. A prototype tsunami meter was installed there on GEOSTAR (Geophysical and Oceanographic STation for Abyssal Research) with near-real-time data transmission through an acoustic link from the seafloor observatory to the surface buoy and through a satellite link from the buoy to the shore. (Favali et al. 2006a). The ESONET demonstration mission, LIstening to the Deep Ocean environment (LIDO), is also researching passive acoustics related to marine mammals and anthropogenic noise, and geo-hazard research.

The Ligurian Sea near the south coast of France in the Mediterranean has active research in sub-sea geophysics, slope stability, biogeochemical fluxes and marine ecology. The study area has sites extending to $2500 \mathrm{~m}$ depth in the MEDI biogeochemical region with wind driven coastal upwelling, particle plumes, nutrient benthic exchange, bottom boundary layer processes, and mesoscale research. Previous and existing programmes operating in the area included EuroSITES, JGOFS - Dynamics of Atmospheric Fluxes in the MEDiterranean sea (DYFAMED; $43.25^{\circ} \mathrm{N}, 7.52^{\circ} \mathrm{E}$ ), International Ocean Drilling Program (IODP), and ANTARES (Astronomy with a Neutrino Telescope and Abyss environmental RESearch), one of the candidate sites for the KM3NeT infrastructure, which provides seafloor cable infrastructure.

The study area offshore of East Sicily is located in one of the most seismically active areas of Mediterranean in the vicinity of Mount Etna and MEDI biogeochemical region at a depth of $2100 \mathrm{~m}$. On-going research at the site includes work related to LIDO and the NEMOSN1 multidisciplinary observatory, which has been cabled since 2005 (Favali et al. 2006b, Favali et al. 2010a). The site benefits from seafloor cabled infrastructure support of the NEMO (NEutrino Mediterranean Observatory) neutrino telescope, another candidate for the KM3NeT (Migneco et al. 2006, 2008). Seismic, tsunami, and Mediterranean Intermediate Water formation are particularly important topics at this site, which also has used GEOSTAR technology.

The E2-M3A in the Adriatic Sea $\left(41.84^{\circ} \mathrm{N}, 17.76^{\circ} \mathrm{E}\right)$ has been the location of ocean biogeochemical research in association with EuroSITES. Research at the site focuses on heat flux and convection (e.g. Cardin and Gacic 2003). Further to the southeast in the Mediterranean is the Hellenic study area over a series of four networks including a cabled system (NESTOR, another KM3NeT candidate site), EuroSITES Poseidon E1-M3A 
$\left(35.66^{\circ} \mathrm{N}, 24.99^{\circ} \mathrm{E}\right)$, the IODP site BUTT-1 (34 $\left.18.6 \mathrm{~N}, 24^{\circ} 54.3 \mathrm{E}\right)$, and the Cretan and Rhodes basins. Research in the area examines benthic-pelagic interactions, benthic respiration, biogeochemical fluxes, and photography based ecology, as well as monitoring seismic processes, seabed methane fluxes, and oil and gas industry activities.

The Sea of Marmara, which lies between the Mediterranean and Black Sea, experiences regular tectonic activity because of its location on the North Anatolian Fault which is a major continental transform plate boundary. The fault cuts across a natural gas field beneath the Sea of Marmara and hydrocarbons seep from the seafloor. An ESONET demonstration mission is testing for possible relationships between fluid activity and seismicity at the site. After the 1999 Izmit and Düzce earthquakes, the next large earthquake $\left(M_{w}>7\right)$ is expected in the Sea of Marmara close to Istanbul, a city with 15 million inhabitants (Parsons, 2004). Hence, the high tectonic activity and oceanographic setting makes the area a natural laboratory for multidisciplinary seafloor observations for geo-hazards, oceanography, and the relationship between fluids and seismicity. Improved geo-hazard warning is needed here where earthquake and tsunami hazards could have devastating effect in Istanbul and heavily populated coastal areas (e.g. Yalçıner et al., 2002; Görür and Çağatay, 2010).

The Black Sea is an area of research on extreme habitats, as well as geo-hazards like methane hydrate release (Blinova et al. 2005, Schmale, 2005, Greinert et al. 2006). Methane seeps have been mapped extensively in the Black Sea providing an excellent setting for longterm research of links between methane gas flux, seismicity, and ecology. The co-occurrence of these processes presents a good opportunity to understand the biogeochemical implications of methanotrophy.

\subsection{Generic Sensor Module}

The concepts of generic and specific aspects of observatory design are helping to guide observatory development in Europe. In practice the ability to address most questions has limits because one given site is not optimum for all applications. For instance, certain geohazard monitoring is best implemented in geologically active areas. Similarly marine communities, such as those linked to hydrothermal vents and cold seeps can be highly localised. There are, however, several variables that are sensible at all sites and depths, including temperature, conductivity [salinity], pressure [depth], turbidity, dissolved oxygen, carbon dioxide, ocean currents, and passive acoustics. Variants that include pelagic and benthic specialisation are also being developed with, for example, chlorophyll fluorescence, or time-lapse cameras respectively.

These generic module concepts can then be adopted and serve as the primary means for comparisons of processes between sites and core service of the system. The variables measured with the generic sensor module cover a subset of variables that are important in the context of climate system monitoring known as Essential Climate Variables (ECV) supporting the work of the UN Framework Convention on Climate Change (UNFCCC) and the IPCC.

These generic sensor variables have been operational for long time periods and are commercially available. Hence, they can be used and maintained with relative ease. Multiprobe, CTD-type (conductivity, temperature, and depth) systems often come with a basic set of sensors (Table 3) and possibilities to add a wide variety of others. Another advantage of such systems is that data capture and power supply units already have some integration and interoperability standardisation. As sensor development continues other variables can be added, such as the remaining ECV. Sensors for $\mathrm{pH}, \mathrm{CH}_{4}, \mathrm{H}_{2} \mathrm{~S}$, Eh, and hydrocarbons are likely to become part of the generic scheme as sensors for them become adapted for observatories.

\subsection{Science-Specific Modules}


The science-specific sensor modules are designed to complement the generic sensors in addressing the above objectives. Specific modules can be set up in varying combinations according to site-specific objectives. For example, measuring synchronously seismic motion, gravity, magnetism, seafloor deformation, sedimentation, pore-water properties, gas hydrates, and fluid dynamics will provide a great opportunity to make advancements in geosciences and geo-hazard early-warning capability. Specific observatory applications in physical and biogeochemical oceanography require full water depth moorings that allow recording of longterm, high resolution time-series of hydrography, currents and biogeochemical state variables (oxygen, fluorescence, nutrients) throughout the water column. A suite of biogeochemical and physical sensors mounted on moored profilers can allow for high-resolution vertical profiling in the upper part of the water column. Hydrothermal vent systems need instrumentation for extreme conditions. Systems for more specialised biogeochemical research include sedimentation trap systems, pigment and hydrocarbon fluorescence sensors, and in situ mass spectrometry. Observatory systems addressing aspects of marine ecology include deepbiosphere monitoring systems, time-lapse and video imaging, active acoustics, plankton sampling, in situ respiration, and in situ molecular and genetic analysis. Acoustic systems, which use advanced signal processing, are capable of not only acoustic tomography and source localisation, but also recognition of shapes in water.

\subsection{Data Infrastructure}

The data infrastructure for European observatories is being designed as a distributed system. Both observatory data and archiving services are already provided by several data centres. Therefore, the main challenge is to provide architecture based on international standards to implement data management policies and work flows. ESONET has a developing online knowledge base for general information about observatory systems and how projectspecific data management fits into larger contexts. Core standards include the Open Geospatial Consortium (OGC) Sensor Web Enablement (SWE) suite of standards, namely the OGC standards SensorML, Sensor Registry, Catalogue Service for Web (CS-W), Sensor Observation Service (SOS) and Observations and Measurements (O\&M) (Fig. 13). OGC SensorML is an eXtensible Markup Language (XML) for describing sensor systems and processes. A core SensorML profile is being developed in cooperation with EuroSITES and OceanSITES to assure international compatibility of sensor descriptions. SensorML files can be stored in the Sensor Registry, the main catalogue of European ocean observatory sensors. The Sensor Registry consists of a web-based entry module which stores the SensorML files in a native XML database. On top of this database, an OGC CS-W interface provides the standardised methodology to publish and access the Sensor Registry. Access to real-time observatory data is then provided by the SOS. Delayed mode data can also be entered into the system through the SOS.

The SOS service harvests data for automated data flow from observatory nodes to a selected data archive. OGC standards are used to generate International Standardisation Organization (ISO) 19139 compliant metadata descriptions for the harvested data. O\&M and

ISO data is then uploaded to an appropriate data centre and ingested. Currently, the World Data Center for Marine Environmental Sciences (WDC-MARE) as well as Systèmes d'Informations Scientifiques pour la Mer (SISMER) are implementing routines to acquire data from observatories and are capable of long-term data archiving services. In addition, both data archives provide data curatorial procedures including quality control for manual or semiautomatic upload of data to the archive. Each data archive further provides XML metadata files on each data set in either ISO 19139 or Global Change Master Directory - Directory Interchange Format (GCMD DIF) format and offers metadata exchange via Open Archives Initiative Protocol for Metadata Harvesting (OAI-PMH) interface. As quality control and 
other post-acquisition processing are applied to data, these data can be catalogued alongside their raw counterparts.

The knowledge base uses the above standards to data from observatories via the internet. For example, it uses OAI-PMH to harvest metadata from contributing archives and uses SOS to retrieve the latest data from observatories. The technical platform managing the metadata catalogue of contributing data archives is panFMP (PANGAEA Framework for Metadata Portals, Schindler and Diepenbroek 2008). The knowledge base provides access to sensor metadata via the Sensor Registry and offers access to real-time and archived data delivered by the SOS servers, as well as access to third party data centres which support the standards described above.

\section{Conclusions}

The scientific questions posed above derive from elemental societal needs to understand the marine environment and its influences. While many basic aspects of ocean systems have been described, major uncertainties in understanding the factors controlling variations in the ocean remain, let alone the variation that might occur as a result of climate change. Important episodic variations are often missed resulting in major quantitative imbalances. Uncertainty about deep-water industrial impact is also still high. Deficiency in understanding results, in part, from the fact that geophysical, chemical, ecological and biological quantities can be simultaneously influenced by a complex set of factors over a wide range of spatial and temporal scales.

Multidisciplinary standardised reference data will facilitate interdisciplinary analysis required to improve geo-hazard warning, and effectively evaluate the influences of climate change and anthropogenic impacts. By including a variety of tools investigators will be able to make connections between processes that are usually observed in disparate ways using meta-analysis (Zwiers and Hegerl 2008). The resulting variation can importantly be influenced by linear, as well as non-linear dynamics where seemingly similar conditions may result in different outcomes (Scheffer et al. 2001). Therefore attentive monitoring of multivariate environmental and resource conditions over adequate spatial and temporal scales is necessary. This notion includes a need to verify outcomes of studies examining spatial gradients as a proxy for understanding temporal change.

Complementary to the observational and experimental research is the clear need to place the complex results into rigorous theoretical frameworks and models where the complexity can be addressed such as the Nucleus for European Modelling of the Ocean (NEMO) and more specific tools like diagenetic and food web models (Soetaert and van Oevelen 2009). Forecasts now cover physical state variables such as temperature, salinity, currents, and waves, but forecast extensions to include marine ecosystem variables are under development. Addressing the major gaps with data from fixed point systems extending below $2000 \mathrm{~m}$ depth should improve longer-term forecasting.

Continued harmonisation of links among developing European large-scale infrastructures like, Euro-Argo, EMSO, KM3NeT, EPOS, SIOS, ICOS, and LIFEWATCH is needed (ESFRI, 2008). More direct engagement with maritime industries could continue to improve access to observatory infrastructure and enhance scientific outputs and industrial best practices. Many questions outlined will require information from other sources such as climate analysis and measurements from satellites or drifting floats such as Argo. Further development of ocean observatories will ultimately allow for increased data and infrastructure to those that may not otherwise have access, a benefit that was found during the HERMES project (Weaver and Gunn, 2009). 
Economic stability, health and well being rely now more than ever on sound information on climate, weather, water, ecosystems, biodiversity, living resources, energy resources, and geo-hazards. Investing in ocean observatories will be a key development in realising an effective global observation system that aims to address these many needs. The results of these observatory efforts will contribute to EMODNET, GEOSS, GMES, geohazard networks, and will inform work in UNEP, OSPAR, and the interannual IPCC Assessment Reports.

\section{Acknowledgments}

We would like to acknowledge the many who contributed to the preparation and revision of this document including C. Berndt, T. Aarup, Y. Desaubies, Y. Auffret, P. Lasserre, A. Grehan, and W-D Longree. The preparation of this manuscript was supported by the European Seas Observatory NETwork Network of Excellence (ESONET NoE), a Sixth Framework Programme of the European Commission, and the European Multidisciplinary Seafloor Observatory Preparatory Phase (EMSO-PP), a project of the Seventh Framework Program of the European Commission.

\section{References}

Alldredge, A.L, Passow, U., Logan, B.E., 1993.The abundance and significance of a class of large, transparent organic particles in the ocean. Deep-Sea Research 40, 11311140.

Allen, J.T., Brown, L., Sanders, R., Moore, C.M., Mustard, A., Fielding, S., Lucas, M., Rixen, M., Savidge, G., Henson, S., Mayor D., 2005. Diatom carbon export enhanced by silicate upwelling in the northeast Atlantic. Nature 437, 728-732.

Altabet, M.A., 2007. Constraints on oceanic N balance/imbalance from sedimentary 15N records. Biogeosciences 4, 75-86.

Althaus, F.A., Williams, T.A., Schlacher, R.J., Kloser, M.A., Green, B.A., Barker, N.J., Bax, P., Brodie, M.A., Schlacher-Hoenlinger, 2009. Impacts of bottom trawling on deep-coral ecosystems of seamounts are long-lasting. Mar. Ecol. Prog. Ser. 397, 279-294.

Anderson, C.N.K., Hsieh, C.H., Sandin, S.A., Hewitt, R., Hollowed, A., Beddington, J., May, R.M., Sugihara, G., 2008. Why fishing magnifies fluctuations in fish abundance. Nature 452, 835-839.

André, M., Nachtigall, P.E.,, 2007. Electrophysiological measurements of hearing in marine mammals. Aquatic Mammals, 33: 1-5.

Archer, D., Buffett, B., Brovkin, V., 2009. Ocean methane hydrates as a slow tipping point in the global carbon cycle. Proc. Nat. Acad. Sci. USA 106, 20596-20601.

Archer, D., 2007. Methane hydrate stability and anthropogenic climate change. Biogeosciences 4, 521-544.

Armstrong, C.W., Grehan, A. J., Kahui, V., Mikkelsen, E., Reithe, S., van den Hove, S., 2009. Bioeconomic modeling and the management of cold-water coral resources. Oceanography 22, 92-97.

Armstrong, R.A., Lee, C., Hedges, J.I., Honjo, S., Wakeham, S.G., 2002. A new, mechanistic model for organic carbon fluxes in the ocean based on the quantitative association of POC with ballast minerals. Deep-Sea Research II, 219-236.

Arrigo, K.R., 2005. Marine micro-organisms and global nutrient cycles. Nature, 437, 349355. 
Arzola, R.G., Wynn, R.B., Lastras, G., Masson, D.G., Weaver, P.P.E., 2008.Sedimentary features and processes in the Nazaré and Setúbal submarine canyons, west Iberian margin. Marine Geology 250, 64-88.

Attrill, M.J., Power, M., 2002. Climatic influence on a marine fish assemblage. Nature 417, 275-278.

Avsic, T., Karstensen, J., Send, U., Fischer, J., 2006. Interannual variability of newly formed Labrador Sea Water from 1994 to 2005. Geophysical Research Letters 33, L21S02, 10.1029/2006GL026913.

Azam, F., Fenchel, T., Field, J.G., Gray, J.S., Meyer-Reil, L.A., Thingstad, F., 1983. The ecological role of water-column microbes in the sea. Marine Ecology Progress Series10, 257-263.

Azam, F., Long, R.A., 2001. Sea snow microcosms. Nature 414, 495-498.

Bachraty, C., Legendre, P., Desbruyères, D., 2009. Biogeographic relationships among deepsea hydrothermal vent faunas at global scale. Deep-Sea Research I 56, 1371-1378.

Bailey, D.M., Collins, M.A., Gordon, J.D.M., Zuur, A.F., Priede, I.G., 2009. Long-term changes in deep-water fish populations in the North East Atlantic: a deeperreaching effect of fisheries? Proceedings of the Royal Society B: Biological Sciences, doi:10.1098/rspb.2009.0098.

Baldwin, R.J., Glatts, R.C., Smith, K.L., Jr., 1998. Particulate matter fluxes into the benthic boundary layer at a long time-series station in the abyssal NE Pacific: composition and fluxes. Deep-Sea Research II 45, 643-666.

Balmaseda, M.A., Anderson, D., 2009. Impact of initialization strategies and observations on seasonal forecast skill. Geophys. Res. Lett. 36, L01701, doi:10.1029/2008GL035561.

Baptista, M.A., Heitor, S., Miranda, J.M., Miranda, P., Mendes Victor, L., 1998.The 1755 Lisbon Tsunami: Evaluation of the Tsunami parameters. J. Geodynamics 25, 143157.

Baran, P.S., Maimone, T.J., Richter J.M. 2007. Total synthesis of marine natural products without using protecting groups. Nature 446, 404-408.

Barnes, C.R., Best, M.M.R., Zielinski, A, 2008. The NEPTUNE Canada regional cabled ocean observatory. Sea Technology 49, 10-14.

Barnett, T.P., Pierce, D.W., AchutaRao, K.M., Gleckler, P.J. Santer, B.D. Gregory, J.M., Washington, W.M., 2005. Penetration of human-induced warming into the world's oceans. Science 309, 284-287.

Bashmachnikov, I., Lafon, V., Martins, A., 2004. SST stationary anomalies in the Azores region. In: Remote Sensing of Ocean and Sea Ice, Proceedings of SPIE Vol. 5569, 148-155.

Bashmachnikov, I., Mohn, C., Pelegri, J.L, Martins, A., Machin, F., Jose, F., White, M., 2009. Interaction of Mediterranean water eddies with Sedlo and Seine seamounts, Subtropical Northeast Atlantic. Deep-Sea Research II 56, 2593-2605.

Bauer, J.E., Druffel, E.R.M., 1998. Ocean margins as a significant source of organic matter to the deep open ocean. Nature 392, 482-485.

Beaugrand, G., Brander, K.M., Lindley, J. A., Souissi, S., Reid, P.C., 2003. Plankton effect on cod recruitment in the North Sea. Nature 426, 661-664.

Behrenfeld, M.J., O’Malley, R.T. Siegel, D.A. McClain, C.R. Sarmiento, J.L. Feldman, G.C., Milligan, A. J., Falkowski, P.G., Letelier, R.M., Boss, E.S., 2006. Climate-driven trends in contemporary ocean productivity. Nature 44, 752-755.

Benitez-Nelson, C.R., Bidigare, R.R., Dickey, T.D., Landry, M.R., Leonard, C.L., Brown, S.L., Nencioli, F., Rii, Y.M., Maiti, K., Becker, J.W., Bibby, T.S., Black, W., Cai, W.-J., Carlson, C.A., Chen, F., Kuwahara, V.S., Mahaffey, C., McAndrew, P.M., 
Quay, P.D., Rappé, M.S., Selph, K.E., Simmons, M.P., Yang, E.J., 2007.

Mesoscale eddies drive increased silica export in the subtropical Pacific Ocean. Science 316, 1017-1021.

Bennett, S.A., Achterberg, E.P., Connelly, D.P., Statham, P.J., Fones, G.R. German, C.R., 2008. The distribution and stabilisation of dissolved Fe in deep-sea hydrothermal plumes. Earth and Planetary Science Letters 270, 157-167.

Beranzoli, L., Favali, P., Smriglio, G. (Eds.), 2002. Science-Technology Synergy for Research in the Marine Environment: Challenges for the XXI Century, Developments in Marine Technology, 12, 268 pp., Elsevier, Amsterdam.

Berndt, C., 2005. Focused fluid flow in passive continental margins. Philosophical Transactions of the Royal Society A: Mathematical, Physical and Engineering Sciences 363, 2855-2871.

Berta, M., Gasparoni, F., Capobianco, M., 1995. Abyssal Benthic Laboratory (ABEL): a novel approach for long-term investigation at abyssal depths. Journal Marine Systematics 6, 211-225.

Bianchelli, S., Gambi, C., Pusceddu, A., Danovaro, R., 2008. Trophic conditions and meiofaunal assemblages in the Bari Canyon and the adjacent open slope (Adriatic Sea). Chemistry and Ecology 24, 101-109.

Biddle, J.F., Lipp, J.S., Lever, M.A., Lloyd, K.G., Sørensen, K.B., Anderson, R., Fredricks, H.F., Elvert, M., Kelly, T.J., Schrag, D.P., Sogin, M.L., Brenchley, J.E., Teske, A., House, C.H., Hinrichs, K.-H., 2008. Heterotrophic Archaea dominate sedimentary subsurface ecosystems off Peru. Proceedings of the National Acadamy of Sciences USA 103, 3846-3851.

Billett, D.S.M., Bett, B.J., Reid, W.D.K., Boorman, B., Priede, I.G., 2010. Long-term change in the abyssal NE Atlantic: The 'Amperima Event' revisited. Deep-Sea Research II 57, 1406-1417.

Billett, D.S.M., Bett, B.J., Rice, A.L., Thurston, M.H., Galeron, J., Sibuet, M., Wolff, G.A., 2001. Long-term change in the megabenthos of the Porcupine Abyssal Plain (NE Atlantic). Progress in Oceanography, 50, 325-348.

Bindoff, N. L., J. Willebrand, V. Artale, A. Cazenave, J. Gregory, S. Guleve, K. Hanawa, C. Le Quere, S. Levitus, Y. Nojiri, C. K. Shum, L. D. Talley, and A. Unnikrishnan, 2007: Observations: Oceanic Climate Change and Sea Level. In: Climate Change 2007: The Physical Science Basis. Contrib. Working Group I Fourth Assessment Report of the IPCC. [S. Solomon, D. Qin, J. Manning, Z. Chen, M. Marquis, K. B. Averyt, M. Tignor, and H. L. Miller (eds)]. Cambridge Univ. Press, Cambridge, U. K., 385-428.

Blackford, J., Jones, N., Proctor, R., Holt, J., Widdicombe, S., Lowe, D., Rees, A., 2009. An initial assessment of the potential environmental impact of CO2 escape from marine carbon capture and storage systems. Proceedings of the Institution of Mechanical Engineers A - Journal of Power and Energy 223, 269-280.

Blair, C., D'Hondt, S., Spivack, A.J., Kingsley, R.H., 2007. Radiolytic hydrogen and microbial respiration in subsurface sediments. Astrobiology 7, 951-970.

Blandin, J., Rolin, J.F., 2005. An array of sensors for the seabed monitoring of geohazards: A versatile solution for the long-term real-time monitoring of distributed seabed parameters. Sea Technology 46, 33.

Blinova, V., Ivanov, M., Sahling, H., Bohrmann, G., 2005. Geochemical characteristics and origin of the hydrocarbon gases from seepage areas offshore Georgia and Turkey in the Black Sea (P317/4-cruise), International Workshop on Methane in sediments and water column of the Black Sea: Formation, transport pathways and the role within carbon cycle. Sevastopol, Ukraine 17.05. - 20.05. 
Boccaletti, G., Ferrari, R., Adcroft, A., Ferreira, D., Marshall, J., 2005. The vertical structure of ocean heat transport. Geophysical Research Letters 32, doi:10.1029/2005GL022474.

Boetius, A., Ravenschlag, K., Schubert, C., Rickert, D., Widdel, F., Gieseke, A., Amann, R., Jørgensen, B.B., Witte, U., Pfannkuche, O., 2000. A marine microbial consortium apparently mediating anaerobic oxidation of methane. Nature 407, 623-626.

Boetius, A., Suess, E., 2004. Hydrate Ridge: a natural laboratory for the study of microbial life fueled by methane from near-surface gas hydrates. Chem. Geol. 205, 291-310.

Bohrmann, G., Ivanov, M., Foucher, J.P., Spiess, V., Bialas, J., Weinrebe ,W., Abegg, F., Aloisi, G., Artemov, Y., Blinova, V., Drews, M., Greinert, J., Heidersdorf, F., Krastel, S., Krabbenhöft, A., Polikarpov, I., Saburova, M., Schmale, O.,Seifert, R., Volkonskaya, A., Zillmer, M., 2003. Mud volcanoes and gas hydrates in the Black Sea - new data from Dvurechenskii and Odessa mud volcanoes. GeoMarine Letters 23, 239-249.

Bondevik, S., Svendsen, J.I., Mangerud, J., 1997.Tsunami sedimentary facies deposited by the Storegga tsunami in shallow marine basins and coastal lakes, western Norway. Sedimentology 44, 1115-1131.

Bopp, L., Aumont, O., Cadule, P., Alvain, S., Gehlen, M., 2005. Response of diatoms distribution to global warming and potential implications: A global model study. Geophys. Research Letters 32, doi:10.1029/2005GL023653.

Borenäs, K., Lundberg, P., 2004. The Faroe-Bank Channel deep-water overflow. Deep-Sea Research II 51, 335-350.

Boschi, E., Guidoboni, E., Ferrari, G., Valensise, G., Gasperini, P., 1997. Catalogue of the strong earthquakes in Italy from 461 BC to 1990. ING-SGA, Bologna, 973 pp.

Bourles, B., Lumpkin, R., McPhaden, M.J., Hernandez, F., Nobre, P., Campos, E., Yu, L., Planton, S., Busalacchi, A., Moura, A. DD, Servain, J, Trotte, J., 2008, The PIRATA program: History, accomplishments, and future directions, Bulletin of the American Meteorolgical Society 89, 1111-1123.

Bowler, C., Karl, D.M., Colwell, R.R., 2009. Microbial oceanography in a sea of opportunity. Nature 459, 180-184.

Boyce, D.G., Lewis, M.R., Worm, B., 2010. Global phytoplankton decline over the past century. Nature 466, 591-596.

Boyd, P., Jickells, T., Law, C.S., Blain, S., Boyle, E.A., Buessler, K.O., Coale, K.H., Cullen, J.J., de Baar, H.J.W., Follows, M., Harvey, M.C., Lancelot, C., Levasseur, M., Pollard, R., Rivkin, R.B., Sarmiento, J.L., Schoemann, V., Smetacek, V., Takeda, S., Tsuda, A., Turner, S., Watson, A.J., 2007. Mesoscale iron enrichment experiments 1993-2005: synthesis and future directions. Science 315, 612-617.

Boyer, T., Levitus, S., Antonov, J., Locarnini, R., Mishonov, A., Garcia, H., Josey, S.A., 2007. Changes in freshwater content in the North Atlantic Ocean 1955-2006. Geophysical Research Letters 34, doi:10.1029/2007GL030126.

Brander, K.M., 2007. Global fish production and climate change, Proceedings of the National Academy of Sciences, USA 104, 19709-19714.

Brewer, P.G., Peltzer, E.D., 2009. Limits to marine life. Science 324, 347-348.

Broecker, W.S., Thermohaline circulation, the Achilles heel of our climate system: Will manmade $\mathrm{CO}_{2}$ upset the current balance? Science 278, 1582-1588.

Bucciarelli, E., Pondaven, P., Sarthou, G., 2010.Effects of an iron-light co-limitation on the elemental composition ( $\mathrm{Si}, \mathrm{C}, \mathrm{N}$ ) of the marine diatoms Thalassiosira oceanica and Ditylum brightwellii. Biogeosciences, 7, 657-669.

Buesseler, K.O., Lamborg, C.H., Boyd, P.W., Lam, P.J., Trull, T.W., Bidigare, R.R., Bishop, J.K.B., Casciotti, K.L., Dehairs, F., Elskens, M., Honda, M., Karl, D.M., Siegel, 
D.A., Silver, M.W., Steinberg, D.K., Valdes, J., Mooy, B.V., Wilson, S. 2007.

Revisiting carbon flux through the ocean's twilight zone. Science 316, 567-570.

Buesseler, K.O., Doney, S.C., Karl, D.M., Boyd, P.W., Caldeira, K., Chai, F., Coale, K.H., de

Baar, H.J.W., Falkowski, P.G., Johnson, K.S., Lampitt, R.S., Michaels, A.F.,

Naqvi, S.W.A., Smetacek, V., Takeda, S., Watson, A.J., 2008. Ocean Iron

Fertilization - Moving Forward in a Sea of Uncertainty. Science 319, 161.

Burd, A.B., Hansell, D.A., Steinberg, D.K., Anderson, T.R., Arístegui, J., Baltar, F., Beaupré, S.R., Buesseler, K.O., DeHairs, F., Jackson, G.A., Kadko, D.C., Koppelmann, R., Lampitt, R.S., Nagata, T., Reinthaler, T., Robinson, C., Robison, B.H., Tamburini, C., Tanaka, T., 2010. Assessing the apparent imbalance between geochemical and biochemical indicators of meso-and bathypelagic biological activity:What the @ $\$$ ]! is wrong with present calculations of carbon budgets? Deep-Sea Research II 57, 1557-1571.

Burd, A.B., Jackson, G.A., 2002. Modeling steady-state particle size spectra. Environmental Science and Technology 36, 323-327.

Burrato, P., Poli, M.E., Vannoli, P., Zanferrari, A., Basili, R., Galadini, F., 2008. Sources of M-w 5+ earthquakes in northeastern Italy and western Slovenia: An updated view based on geological and seismological evidence. Tectonophysics 453, 157-176.

Çağatay, M.N., Belucci, L., Polonia, A., Sancar, U., Dikçe, D., Eriş, K., Damci, E., Gasperini, L., Görür, N., Henry, P., Zitter, T.A.C., Geli, L., Tryon, M., 2008. Sedimentary earthquake records in the Sea of Marmara. EGU General Assembly 2008, Vienna, EGU2008-A-05412.

Camilli, R., Reddy, C.M., Yoerger, D.R., Van Mooy, B.A.S., Jakuba, M.V., Kinsey, J.C., McIntyre, C.P., Sylva, S.P., Maloney, J.V., 2010. Tracking Hydrocarbon Plume Transport and Biodegradation at Deepwater Horizon. Science 330, 201-204.

Canadell, J.G., Le Quéré, C., Raupach, M.R., Field, C.B., Buitehuis, E.T., Ciais, P., Conway, T.J., Houghton, R.A., Marland, G., 2007. Contributions to accelerating atmospheric $\mathrm{CO}_{2}$ growth from economic activity, carbon intensity, and efficiency of natural sinks. Proceedings of the National Academy of Science USA 104, 18866-18870.

Canals, M., Danovaro, R., Heussner, S., Lykousis, V., Puig, P., Trincardi, F., Calafat, A.M., Durrieu de Madron, X., Palanques, A., Sànchez-Vida, A., 2009. Cascades in Mediterranean Submarine Grand Canyons. Oceanography 22, 32-49.

Canals, M., Puig, P., Durrieu de Madron, X., Heussner, S., Palanques, A., Fabres, J., 2006. Flushing submarine canyons. Nature 444, 354-357.

Cannat, M., Briais, A., Deplus, C., Escartín, J., Georgen, J., Lin, J., Mercouriev, S., Meyzen, C., Muller, M., Pouliquen, G., Rabain, A., da Silva, P., 1999. Mid-Atlantic ridge Azores hotspot interactions: Along-axis migration of a hotspot-derived magmatic pulse 14 to 4 myrs ago. Earth Planetary Science Letters 173, 257-269.

Capone, D.G., Zehr, J.P., Paerl, H.W., Bergman, B., Carpenter, E.J., 1997. Trichodesmium, a globally significant marine cyanobacterium. Science 276, 1221-1229.

Cardin, V., Gačić, M.,8103, doi:10.1029/2002JC001645.Catchpole, A., Auliciems, A., 1999. Southern oscillation and the northern Australian prawn catch. International Journal of Biometeorology 43, 110-112.

Cayan, D., 1992. Latent and sensible heat flux anomalies over the northern oceans: The connection to monthly atmospheric circulation. Journal of Climate 5, 0894-8755.

Center for Ocean Solutions, 2009. Pacific Ocean synthesis: Scientific literature review of coastal and ocean threats, impacts, and solutions. The Woods Center for the Environment, Stanford University, California. 
Chavez, F.P., Ryan, J.P., Lluch-Cota, S,. Ñiquen M., C., 2003. From anchovies to sardines and back-Multidecadal change in the Pacific Ocean. Science 299, 217-221.

Chen C.T.A., Borges, A.V., 2009. Reconciling opposing views on carbon cycling in the coastal ocean: Continental shelves as sinks and near-shore ecosystems as sources of atmospheric $\mathrm{CO}_{2}$. Deep-Sea Research II 56, 578-590.

Chester, D.K., 2008. The effects of the 1755 Lisbon earthquake and tsunami on the Algarve region, southern Portugal. Geography 93, 78-90.

Chivian, D., Brodie, E.L., Alm, E.J., Culley, D.E., Dehal, P.S., DeSantis, T.Z., Gihring, T.M., Lapidus, A., Lin, L., Lowry, S.R., Moser, D.P., Richardson, P.M., Southam, G., Wanger, G., Pratt, L.M., Andersen, G.L., Hazen, T.C., Brockman, F.J., Arkin, A.P., Onstott, T.C., 2008. Environmental genomics reveals a single-species ecosystem deep within Earth. Science 322, 275-278.

Christensen, J.H., Christensen, O.B., 2003. Climate modelling: Severe summertime flooding in Europe. Nature 421, 805-806.

Clark, C.W., Ellison, W.T., Southall, B.L., Hatch, L., Van Parijs, S.M., Frankel, A., Ponirakis, D., 2009. Acoustic masking in marine ecosystems: intuitions, analysis, and implaction. Mar. Ecol. Prog. Ser. 395, 201-222.

Colaço A., Martins I., Laranjo M., Pires L., Leal C., Prieto C., Costa V., Lopes H., Rosa D., Dando P.R., Serrão-Santos R., 2006. Annual spawning of the hydrothermal vent mussel, Bathymodiolus azoricus, under controlled aquarium conditions at atmospheric pressure. Journal of Experimental Marine Biology and Ecology 333, 166-171.

Colaço, A., Prieto, C., Martins, A., Figueiruedo, M., Lafon, V., Monteiro, M., Bandarra, N.M., 2009. Seasonal variations in lipid composition of the hydrothermal vent mussel Bathymodiolus azoricus from the Menez Gwen vent field. Marine Environmental Research 67, 146-152.

Company, J.B., Puig, P., Sardá, F., Palanques, A., Latasa, M., Scharek R., 2008. Climate influence on deep sea populations. PLoS ONE 3, e1431.

Cosson, N., Sibuet, M., Galéron., J., 1997. Community structure and spatial heterogeneity of the deep-sea macrofauna at three contrasting stations in the tropical northeast Atlantic. Deep-Sea Research I 44, 247-269.

Costello, M., McCrea, M., Freiwald, A., Lundälv, T., Jonsson, L., Bett, B., van Weering, T., de Haas, H., Roberts. J., Allen, D., 2005. Role of cold-water Lophelia pertusa coral reefs as fish habitat in the NE Atlantic. In: Friewald A, Roberts JM (eds) Cold-water corals and ecosystems. Springer, Berlin, p 771-805

Coumou, D., Driesner, T., Heinrich, C.A., 2008. The structure and dynamics of mid-ocean ridge hydrothermal systems. Science 321, 1825-1828.

Cowen, J.P., Bertram, M.A., Wakeham, S.G., Thomson, R.E., Lavelle, J.W., Baker, E.T., Feely, R.A., 2001. Ascending and descending particle flux from hydrothermal plumes at Endeavour Segment, Juan de Fuca Ridge. Deep-Sea Research I 48, 1093-1120.

Cromwell, D., 2006. Temporal and spatial characteristics of sea surface height variability in the North Atlantic Ocean. Ocean Science 2, 147-159.

Cunningham, S.A., Kanzow, T., Rayner, D., Baringer, M.O., Johns, W.E., Marotzke, J., Longworth, H.R., Grant, E.M., Hirschi, J.J.-M., Beal, L.M., Meinen, C.S., Bryden, H.L., 2007. Temporal variability of the Atlantic Meridional Overturning Circulation at $26.5^{\circ} \mathrm{N}$. Science 317 , 935-938.

Curry, R., Mauritzen, C., 2005. Dilution of the Northern Atlantic Ocean in recent decades. Science 308, 1772-1774. 
Danovaro, R., Dell’Anno, A., Corinaldesi, C., Magagnini, M., Noble, R., Tamburini, C., Weinbauer, M., 2008a. Major viral impact on the functioning of benthic deep-sea ecosystems. Nature 454, 1084-1087.

Danovaro, R., Dell'Anno, A., Puscuddu, A., 2004. Biodiversity response to climate change in a warm deep sea. Ecology Letters 7, 821-828.

Danovaro, R., Gambi, C., Dell’Anno, A., Corinaldesi, C., Fraschetti, S., Vanreusel, A., Vincx, M., Gooday, A.J., 2008b. Exponential decline of deep-Sea ecosystem functioning linked to benthic biodiversity loss. Current Biology 18, 1-8.

Davies, A.J., Duineveld, G.C.A., Lavaleye, M.S.S., Bergman, M.I.N., van Haren, H., Roberts, J. M., 2009. Downwelling and deep-water bottom currents as food supply mechanisms to the cold-water coral Lophelia pertusa (Scleractinia) at the Mingulay Reef Complex. Limnol. Oceanogr., 54, 620-629.

del Giorgio, P.A., Cole, J.J., Cimbleris, A., 1997. Respiration rates in bacteria exceed phytoplankton production in unproductive aquatic systems. Nature 385, 148-151.

Dell'Anno, A., Danovaro, R., 2005. Extracellular DNA plays a key role in deep-sea ecosystem functioning. Science 309, 2179.

Delille, B., Harlay, J., Zondervan, I., Jacquet, S., Chou, L., Wollast, R., Bellerby, R.G.J., Frankignoulle, M., Borges, A.V., Riebesell, U., Gattuso, J.-P., 2005. Response of primary production and calcification to changes of $p \mathrm{CO}_{2}$ during experimental blooms of the coccolithophorid Emiliania huxleyi. Global Biogeochemical Cycles 19, doi: 10.1029/2004GB002318,

DeLong, E.F., 2009. The microbial ocean from genomes to biomes. Nature 459, 200-206.

Deuser, W.G., Ross, E.H., 1980. Seasonal change in the flux of organic carbon to the deep Sargasso Sea. Nature 283, 364-365.

Deutsch, C., Sarmiento, J.L., Sigman, D.M., Gruber, N., Dunne, J.P., 2007. Spatial coupling of nitrogen inputs and losses in the ocean. Nature 445, 163-167.

D’Hondt, S., Jørgensen, B.B., Miller, D.J., Batzke, A., Blake, R., Cragg, B.A., Cypionka, H., Dickens, G.R., Ferdelman, T., Hinrichs, K.-U., Holm, N.G., Mitterer, R., Spivack, A., Wang, G., Bekins, B., Engelen, B., Ford, K., Gettemy, G., Rutherford, S.D., Sass, H., Skilbeck, C.G., Aiello, I.W., Guèrin, G., House, C.H., Inagaki, F., Meister, P., Naehr, T., Niitsuma, S., Parkes, R.J., Schippers, A., Smith, D.C., Teske, A., Wiegel, J., Padilla, C.N. Acosta, J.L.S, 2004. Distributions of microbial activities in deep subseafloor sediments. Science 306, 2216-2221.

Di Iorio, L., Clark, C.W., 2009. Exposure to seismic survey alters blue whale acoustic coummunication. Biology Letters 6, 51-54.

Dickey, T.D., Chang, G.C., 2001. Recent advances and future visions: Temporal variability of optical and bio-optical properties of the ocean. Oceanography 14, 15-29.

Dickson, B., Østerhus, S., 2007. One hundred years in the Norwegian Sea, Norsk Geografisk Tidsskrift. Norwegian Journal of Geography 61, 56-75.

Dickson, B., Yashayaev, I., Meincke, J., Turrell, B., Dye, S., 2002. Rapid freshening of the deep North Atlantic Ocean of the past four decades. Science 416, 832-837.

Dickson B., Dye, S., Jònsson, S., Köhl, A., Macrander, A., Marnela, M., Meincke, J., Olsen, S., Rudels, B., Valdimarsson, H., Voet, G., 2008. The overflow flux west of Iceland: variability, origins and forcing. In: Dickson RR et al. (Eds.), ArcticSubarctic Ocean Fluxes. Springer, Dordrecht, The Netherlands, pp. 427-441.

Dixon, D., Lowe, D., Miller, P., Villemin, G., Colaço, A., Serrão-Santos, R., Dixon, L., 2006. Evidence for seasonal reproduction in the Atlantic vent mussel Bathymodiolus azoricus, and an apparent link to the timing of photosynthetic primary production. Journal of marine Biological Association of United Kingdom 86, 1363-1371. 
Doney, S.C., Schimel, D.S., 2007. Carbon and climate system coupling on timescales from the Precambrian to the Anthropocene. Annual Review of Environment and Resources 32, 31-66.

D’Onghia, G., Maiorano, P., Sion, L., Giove, A., Capezzuto, F., Carlucci, R., Tursi, A., 2010. Effects of deep-water coral banks on the abundance and size structure of the megafauna in the Mediterranean sea. Deep-Sea Res II 57, 397-411.

Dore, J.E., Lukas, R., Sadler, D.W., Karl, D.M., 2003. Climate-driven changes to the atmospheric $\mathrm{CO}_{2}$ sink in the subtropical North Pacific Ocean. Nature 424, 754757.

Drazen, J.C., Baldwin, R.J., K.L. Smith Jr., 1998. Sediment community response to a temporally varying food supply at an abyssal station in the NE pacific. Deep-Sea Research II 45, 893-913.

Drazen, J.C., Popp, B.N., Choy, C.A., Clemente, T., De Forest, L., Smith, K.L., Jr., 2008. Bypassing the abyssal benthic food web: Macrourid diet in the eastern North Pacific inferred from stomach content and stable isotopes analyses. Limnology and Oceanography 53, 2644-2654.

Duce, R.A., LaRoche, J., Altieri, K., Arrigo, K.R., Baker, A.R., Capone, D.G., Cornell, S., Dentener, F., Galloway, J., Ganeshram, R.S., Geider, R.J., Jickells, T., Kuypers, M.M., Langlois, R., Liss, P.S., Liu, S.M., Middelburg, J.J., Moore, C.M., Nickovic, S., Oschlies, A., Pedersen, T., Prospero, J., Schlitzer, R., Seitzinger, S., Sorensen, L.L., Uematsu, M., Ulloa, O., Voss, M., Ward, B., Zamora, L., 2008. Impacts of atmospheric anthropogenic nitrogen on the open ocean. Science 320, 893-897.

Duce, R.A., Tindale, N.W., 1991. Atmospheric transport of iron and its deposition in the ocean. Limnology and Oceanography 36, 1715-1726.

Ducklow, H.W., Steinberg, D.K., Buesseler, K.O., 2001. Upper ocean carbon export and the biological pump, Special Issue - JGOFS. Oceanography, 14 0-58.

Dunne, J.P., Sarmiento, J.L., Gnanadesikan, A., 2007. A synthesis of global particle export from the surface ocean and cycling through the ocean interior and on the seafloor. Global Biogeochemical Cycles 21, doi:10.1029/2006GB002907.

Dushaw, B., Au, W., Beszczynska-Möller, A., Brainard, R., Cornuelle, B., Duda, T., Dzieciuch, M., Fahrbach, E., Forbes, A., Freitag, L., Gascard, J.-C., Gavrilov, A., Gould, J., Howe, B., Jayne, S., Johannessen, O.M., Lynch, J., Martin, D., Menemenlis, D., Mikhalevsky, P., Miller, J.H., Munk, W.H., Nystuen, J., Odom, R., Orcutt, J., Rossby, T., Sagen, H., Sandven, S., Simmen, J., Skarsoulis, E., Stephen, R., Vinogradov, S., Wong, K.B., Worcester, P. F., Wunsch, C., 2010. A Global Ocean Acoustic Observing Network. In Hall, J., Harrison D.E. Stammer, D. (Eds.), Proceedings of the OceanObs'09: Sustained Ocean. Observations and Information for Society conference 2, Venice, Italy, 21-25 September 2009, ESA Publication WPP-306.

Dyhrman, S.T., Chappell, P.D., Haley, S.T., Moffett, J.W., Orchard, E. D. Waterbury, J.B., Webb, E.A., 2006. Phosphonate utilization by the globally important marine diazotroph Trichodesmium. Nature 439, 68-71.

Eden, C., Greatbatch, R.J., 2003. A damped decadal oscillation in the North Atlantic climate system. Journal of Climate 16, 4043-4060.

Edwards, M., Richardson, A.J., 2004. Impact of climate change on marine pelagic phenology and trophic mismatch. Nature 430, 881-884.

Engås, A., Løkkeborg, S., Ona, E., Soldal, A.V., 1996. Effects of seismic shooting on local abundance and catch rates of cod (Gadus morhua) and haddock (Melanogrammus aeglefinus). Canadian Journal of Fisheries and Aquatic Sciences 53, 2238-2249. 
Engel, A., Zondervan, I., Aerts, K., Beufort, L., Benthien, A., Chou, L., Delille, B., Gattuso, J.-P., Harlay, J., Heemann, C., Hoffman, L., Jacquet, S., Nejstgaard, J., Pizay, M.D., Roshelle-Newall, E., Schneider, U., Terbrueggen, A., Riebesell, U., 2005.

Testing the direct effect of $\mathrm{CO}_{2}$ concentration on a bloom of the coccolithophorid Emiliania huxleyi in mesocosm experiments. Limnology and Oceanography 50, 493-507.

Erzini, K., 2005. Trends in NE Atlantic landings (southern Portugal): identifying the relative importance of fisheries and environmental variables. Fisheries Oceanography 14, 195-209.

ESFRI (European Strategy Forum on Research Infrastructures), 2008. European Roadmap for Research Infrastructures, Report 2008, ISBN 978-92-79-10117-5, European Communities, http://cordis.europa.eu/esfri/ roadmap.htm.

Etiope, G., Favali, P. (Eds.), 2004. Geologic emissions of methane from lands and seafloor: mud volcanoes and observing systems. Environmental Geology 46, 987-1135.

Etiope, G., Favali, P., Fuda, J.-L., Italiano, F., Launbenstein, M., Millot C., Plastino, W., 2006. The Benthic Boundary Layer: geochemical and oceanographic data from the GEOSTAR-2 Observatory. Annals of Geophysics 49, 705-713.

Etiope, G., Favali, P. (Eds.), 2004. Geologic emissions of methane from lands and seafloor: mud volcanoes and observing systems. Environmental Geology 46, 987-1135.

Etiope, G., 2006. The Benthic Boundary Layer: geochemical and oceanographic data from the GEOSTAR-2 Observatory. Annals of Geophysics 49, 705-713.

European Commission, 2007. The deep-sea frontier: Science challenges for a sustainable future. Luxembourg, Office for Official Publications of the European Communities, 53 pp., ISBN 92-79-05266-8.

Fabry, V.J., Seibel, B.A., Feely, R.A., Orr, J.C., 2008. Impacts of ocean acidification on marine fauna and ecosystem processes. ICES Journal of Marine Science 65, 414432.

Falkowski, P.G., Barber, R.T., Smetacek, V., 1998. Biogeochemical controls and feedbacks on ocean primary production. Science $281,200-206$.

Fasham, M.J.R., 2003. Ocean biogeochemistry: The role of the ocean carbon cycle in global change, Springer, pp. 297.

Favali, P., Beranzoli, L., 2006. Seafloor observatory science: A review. Annals of Geophysics, 49, 2/3, 515-567.

Favali P., Beranzoli, L., 2009. EMSO: European Multidisciplinary Seafloor Observatory. Nuclear Instruments and Methods in Physics Research Section A: Accelerators, Spectrometers, Detectors and Associated Equipment 602, 21-27.

Favali, P., Beranzoli, L., D’Anna, G., Gasparoni, F., Marvaldi, J., Clauss, G., Gerber, H.W., Nicot, M., Marani, M.P., Gamberi, F., Millot C., Flueh, E.R., 2006a. A fleet of multiparameter observatories for geophysical and environmental monitoring at seafloor. Annals of Geophysics 49, 659-680.

Favali, P., Beranzoli, L., D’Anna, G., Gasparoni, F., Gerber, H.W., 2006b. NEMO-SN-1 The $1^{\text {st }}$ "Real-Time" Seafloor Observatory of ESONET, Nuclear Instruments and Methods in Physics Research Section A: Accelerators, Spectrometers, Detectors and Associated Equipment 567, 462-467.

Favali, P., Beranzoli, L., Italiano, F., Migneco, E., Musumeci, M., Papaleo, R., 2010a. NEMO-SN1 observatory developments in view of the European Research Infrastructures EMSO and KM3NET, Nuclear Instruments and Methods in Physics Research Section A: Accelerators, Spectrometers, Detectors and Associated Equipment (doi: 10.1016/j.nima.2010.04.139). 
Favali, P. Person, R., Barnes, C.R., Kaneda Y., Delaney J.R., Hsu S.-K., 2010b. Seafloor Observatory Science. In Hall, J., Harrison D.E. Stammer, D. (Eds.), Proceedings of the OceanObs'09: Sustained Ocean. Observations and Information for Society conference 2, Venice, Italy, 21-25 September 2009, ESA Publication WPP-306.

Feely, R.A., Sabine, C.L., Lee, K., Berelson, W., Kleypas, J., Fabry, V.J., Millero, F.J., 2004. Impact of Anthropogenic $\mathrm{CO}_{2}$ on the $\mathrm{CaCO}_{3}$ System in the Oceans. Science 305, 362-366.

Feely, R., Sabine, C.L., Martin Hernandez-Ayon, J., Ianson, D., Hales, B., 2008. Evidence for upwelling of corrosive "acidified" seawater onto the continental shelf. Science 320, 1490-1492.

Fenical, W., 1982. Natural-products chemistry in the marine environment. Science 215, 923928.

Fennel, K., Wilkin, J., 2009. Quantifying biological carbon export for the northwest North Atlantic continental shelves. Geoph. Res. Lett. 36, L18605, doi:10.1029/2009GL039818.

Fer, I., Voet, G., Seim, K.S., Rudels, B., Latarius, K., 2010. Intense mixing of the Faroe Bank Channel overflow. Geophys. Res. Lett. 37, L02604, doi:10.1029/2009GL041924.

Field, D.B., Baumgartner, T.R., Charles, C.D., Ferreira-Bartrina, V., Ohman, M.D., 2006. Planktonic foraminifera of the California Current reflect 20th-century warming. Science 311, 63-66.

Fine, M., Tchernov, D., 2007. Scleractinian coral species survive and recover from decalcification. Science 315, 1811-1811.

Flemming, N.C., 2007. Sustained, efficient production of required information and services within Europe. Socio-economic analysis: Scoping report. Report of the European Commission Sixth Framework Programme project SEPRISE.

Fouquet, Y., Ondreas, H., Charlou, J.L., Donval, J.P., Radford-Knoery, J., Costa, I., Lourenço, N., Tivey, M.K., 1995. Atlantic lava lakes and hot vents. Nature 377, 201.

Frugoni, F., Beranzoli, L., Favali P., Basili, A. (Eds.), 2006. Special issue dedicated to Giuseppe Smriglio: From land networks to seafloor observatories. Annals of Geophysics 49, 2/3, 515-879.

Fuhrman, J.A., 1999. Marine Viruses and their biogeochemical and ecological effects. Nature 399, 541-548.

Fuhrman, J.A., 2009. Microbial community structure and its function implications. Nature 459, 193-199.

Fuhrman, J.A., Steele, J.A., 2008. Community structure of marine bacterioplankton: patterns, networks, and relationships to function. Aquatic Microbial Ecology 53, 69-81.

Fuhrman, J.A., Steele, J.A., Hewson, I., Schwalbach, M.S., Brown, M.V., Green, J.L., Brown, J.A., 2008. A latitudinal diversity gradient in planktonic marine bacteria. Proceedings of the National Academy of Sciences USA 105, 7774-7778.

Fukasawa, M., Freeland, H., Perkin, R., Watanabe, T., Uchida, H., Nishina, A., 2004. Bottom water warming in the North Pacific Ocean. Nature 427, 825-827.

Gambi, C., Danovaro, R., 2006. A multiple-scale analysis of metazoan meiofaunal distribution in the deep Mediterranean Sea. Deep-Sea Research I 53, 1117-1134.

Garzoli, S.L., Boebel, O., Bryden, H., Fine, R.A., Fukasawa, M., Gladyshev, S., Johnson, G., Johnson, M., MacDonald, A., Meinen, C., Mercier, H., Orsi, A., Piola, A., Rintoul , S., Speich, S., Visbeck, M., Wanninkhof , R., 2010. Progressing towards global sustained deep ocean observations”. In: Hall, J., Harrison D.E. Stammer, D. (Eds.), Proceedings of the OceanObs’09: Sustained Ocean. Observations and 
Information for Society conference 2, Venice, Italy, 21-25 September 2009, ESA Publication WPP-306.

Galéron, J., Sibuet, M., Vanreusel, A., Mackenzie, K., Gooday, A.J., Dinet, A., Wolff, G.A., 2001. Temporal patterns among meiofauna and macrofauna taxa related to changes in sediment geochemistry at an abyssal NE Atlantic site. Progress in Oceanography 50, 303-324.

Gebruk, A.V., Chevaldonné, P., Shank, T., Lutz, R.A., Vrijenhoek, R.C., 2000. Deep-sea hydrothermal vent communities of Logatchev area $\left(14^{\circ} 45^{\prime} \mathrm{N}\right.$, Mid-Atlantic Ridge): diverse biotopes and high biomass. Journal of the Marine Biological Association of the United Kingdom 80, 383-393.

Géli, L., Henry, P., Zitter, T., Dupré, S., Tryon, M., Çağatay, M.N., Mercier de Lépinay, B., Le Pichon, X., Şengör, A.M.C., Görür, N., Natalin, B., Uçarkuş, G., Özeren, S., Volker, D., Gasperini, L., Burnard , P., Bourlange, S., the Marnaut Scientific Party, 2008. Gas emissions and active tectonics within the submerged section of the North Anatolian Fault zone in the Sea of Marmara. Earth and Planetary Science Letters 274, 34-39

German, C., Von Damm, K.L., 2006. Hydrothermal Processes, in: The oceans \& marine geochemistry (Treatise on geochemistry series, Vol. 6), Elsevier, pp. 181-222.

GITEWS, 2007. The German contribution to the tsunami early warning system for the Indian Ocean, GITEWS report, Potsdam.

Giacomello E. and Menezes G. (2009). CONDOR project: a sharable scientific observatory for studying and monitoring seamount ecosystems. HERMIONE Newsletter, 1: 10.

Glover, A.G., Gooday, A.J., Bailey, D.M., Billett, D.S.M., Chevaldonnè, P., Colaço, A., Copley, J., Cuvelier, D., Desbruyères, D., Kalogeropoulou, V., Klages, M., Lampadariou, N., Lejeusne, C., Mestre, N.C., Paterson, G.L.J., Perez, T., Ruhl, H., Sarrazin, J., Soltwedel, T., Soto, E.H., Thatje, S., Tselepides, A., Van Gaever, S., Vanreusel, A., 2010. Temporal Change in Deep-Sea Benthic Ecosystems: A Review of the Evidence From Recent Time-Series Studies. Advances in Marine Biology 58, DOI: 10.1016/S0065-2881(10)58001-5

Gordon, J.C.D., Gillespie, D., Potter, J., Frantzis, A., Simmonds, M.P., Swift, R., 1998. The effects of seismic surveys on marine mammals. In: Tasker, M.L. and Weir, C. (Eds.), Proceedings of the Seismic and Marine Mammals Workshop London.

Görür, N., Çağatay, M.N., 2009. Geohazards rooted from the northern margin of the Sea of Marmara since the late Pleistocene: A review of recent results. Natural Hazards, 54(2), 583-603.

Greene, C.H., Pershing, A.J., 2007. Climate Drives Sea Change. Science 315, 1084-1085.

Greene, C.H., Pershing, A.J., Conversi, A., Planque, B., Hannah, C., Sameoto, D., Head, E., Smith, P.C., Reid, P.C., Jossi, J., Mountain, D., Benfield, M.C., Wiebe, P.H., Durbin, E., 2003. Trans-Atlantic responses of Calanus finmarchicus populations to basin-scale forcing associated with the North Atlantic Oscillation. Progress in Oceanography 58, 301-312.

Grehan, A.J., van den Hove, S., Armstrong, C.W., Long, R., van Rensburg, T., Gunn, V., Mikkelsen, E., De Mol, B., Hain, S., 2009. HERMES: promoting ecosystembased management and the sustainable use and governance of deep-water resources. Oceanography 22, 154-165.

Greinert, J., Artemov, Y., Egorov, V., De Batist, M., McGinnis, D., 2006. 1300-m-high rising bubbles from mud volcanoes at 2080m in the Black Sea: Hydroacoustic characteristics and temporal variability. Earth and Planetary Science Letters 244, $1-15$. 
Grist, J.P., Marsh, R., Josey, S.A., 2009. On the relationship between the North Atlantic Meridional Overturning Circulation and the surface-forced overturning streamfunction. Journal of Climate 22, 4989-5002.

Gruber, N., Gloor, M., Milakoff Fletcher, S.E., Doney, S.C., Dutiewicz, S., Follows, M., Gerber, M., Jacobson, A.R., Joos, F., Lindsay, K., Menemenlis, D., Mouchet, A., Müller, S.A., Sarmiento, J.L., Takahashi, T., 2009. Oceanic sources, sinks, and transport of atmospheric $\mathrm{CO}_{2}$. Global Biogeochemical Cycles 23, GB1005, doi:10.1029/2008GB003349.

Grottoli, A.G., Rodrigues, L.J., Palardy, J.E., 2006. Heterotrophic plasticity and resilience in bleached corals. Nature 440, 1186-1189.

Guerra, A., González, A.F., Rocha, F., 2004. A review of the records of giant squid in the north-eastern Atlantic and severe injuries in Architeuthis dux stranded after acoustic explorations. International Council for the Exploration of the Sea Annual Science Conference paper CC: 29, Vigo.

Hakkinen, S., Rhines, P.B., 2009. Shifting surface currents in the northern North Atlantic Ocean. J. Geophys. Res. 114, C04005, doi:10.1029/2008JC004883.

Hansen, B., Østerhus, S., Quadfasel, D., Turrell, W., 2004. Already the day after tomorrow? Science 305, 953-954.

Hansen, B., W.R., Turrell, Østerhus, S., 2001. Decreasing overflow from the Nordic seas into the Atlantic Ocean through the Faroe Bank channel since 1950. Nature 411, 927930.

Hare, S.R., Mantua, N.J., 2000. Empirical evidence for North Pacific regime shifts in Pacific North America. Progress in Oceanography 47, 103-145.

Hartman, S., Larkin, K.E., Lampitt, R.S., Lankhorst, M., Hydes, D.J., 2010. Seasonal and inter-annual biogeochemical variations in the Porcupine Abyss Plain 2003-2005 associated with winter mixing and surface circulation. Deep-Sea Research II 57, 1303-1312.

Hátun, H., Sandö, A.B., Drange, H., Hansen, B., Valdimarsson, H., 2005. Influence of the Atlantic subpolar gyre on the thermohaline circulation. Nature 309, 1841-1844.

Heath, M., Beare, D.J., 2008. New primary production in northwest European shelf seas, 1960-2003. Marine Ecology Progress Series 363, 183-203.

Helmke, P., Neuer, S., Conte, M., Lomas, M., Freudenthal, T., 2010. Crossbasin variability of organic carbon export and flux attenuation in the subtropical North Atlantic Gyre. Deep-Sea Research I 57, 213-227.

Henson, S.A., Dunne, J.P., Sarmiento, J.L., 2009, Decadal variability in North Atlantic phytoplankton blooms. Journal of Geophysical Research 114, C04013, doi:10.1029/2008JC005139.

Henson, S.A., Robinson, I., Allen, J.T., Waniek, J.J., 2006b. Effect of meteorological conditions on interannual variability in timing and magnitude of the spring bloom in the Irminger Basin, North Atlantic. Deep-Sea Research 53, 1601-1615.

Henson, S.A., Sanders, R., Holeton, C., 2006a. Timing of nutrient depletion, diatom dominance and a lower-boundary estimate of export production for Irminger Basin, North Atlantic. Mar. Ecol. Prog. Ser. 313, 73-84.

Herfort, L., Loste, E., Meldrum, F., Thake, B., 2004. Structural and physiological effects of calcium and magnesium in Emiliania huxleyi (Lohmann) Hay and Mohler. Journal of Structural Biology 148, 307-314.

Hester, K.C., Peltzer, E.T., Kirkwood, W.J., Brewer, P.G., 2008. Unanticipated consequences of ocean acidification: A noisier ocean at lower $\mathrm{pH}$. Geophysical Research Letters 35, doi:10.1029/2008GL034913. 
Hewson, I., Steele, J.A., Capone, D.G., Fuhrman, J.A., 2006. Remarkable heterogeneity in meso- and bathypelagic bacterioplankton assemblage composition. Limnology and Oceanography 51, 1274-1283.

Hildebrand, J.A., 2009. Anthropogenic and natural sources of ambient noise in the ocean. Mar. Ecol. Prog. Ser. 395, 5-20.

Hirschi, J.J.-M., Killworth, P.D., Blundell, J.R., 2007. Subannual, seasonal and interannual variability of the North Atlantic meridional overturning circulation. Journal of Physical Oceanography 37, 1246-1265.

Hoegh-Guldberg, O., Mumby, P.J., Hooten, A.J., Steneck, R.S., Greenfield, P., Gomez, E., Harvell, C.D., Sale, P.F., Edwards, A.J., Caldeira, K., Knowlton, N., Eakin, C. M., Iglesias-Prieto, R., Muthiga, N., Bradbury, R.H., Dubi, A., Hatziolos, M.E., 2007. Coral reefs under rapid climate change and ocean acidification. Science 318, 1737-1742.

Holt et al. 2009. Down-welling circulation of the northwest European continental shelf: A driving mechanism for the continental shelf carbon pump. Geophys. Res. Lett. 36, L14602.

Honjo, S., Manganini, S.J., Krishfield, R.A., Francois, R., 2008. Particulate organic carbon fluxes to the ocean interior and factors controlling the biological pump: A synthesis of global sediment trap programs since 1983. Progress in Oceanography 76, 217-285.

Horner-Devine, M.C., Silver, J.M., Liebold, M.A., Bohannan, B.J.M., Colwell, R.K., Fuhrman, J.A., Green, J.L., Kuske, C.R., Martiny, J.B.H., Muyzer, G., Øvreås, L., Reysenbach, A.-L., Smith, V.H., 2007. A comparison of taxon co-occurrence patterns for macro- and microorganisms. Ecology 88, 1345-1353.

Hoste, E., Vanhove, S., Schewe, I., Soltwedel, T., Vanreusel, A., 2007. Spatial and temporal variations in deep-sea meiofauna assemblages in the Marginal Ice Zone of the Arctic Ocean. Deep-Sea Research I 54, 109-129

Hsieh, C.H., Kim, H.J., Watson, W., Di Lorenzo, E., Sugihara, G. 2009. Climate driven changes in abundance and distribution of larvae of oceanic fishes in the southern California region. Global Change Biology, doi: 10.1111/j.1365-2486.

Hsieh, C.H., Ohman, M.D., 2006. Biological responses to environmental forcing: the linear tracking window hypothesis. Ecology 87, 1932-1938.

Hsieh, C.H., Reiss, S.C., Hewitt, R.P., Sugihara, G., 2008. Spatial analysis shows fishing enhances the climatic sensitivity of marine fishes. Canadian Journal of Fisheries and Aquatic Sciences 65, 947-961.

Huhnerbach, V., Masson, D.G., 2004. Landslides in the North Atlantic and its adjacent seas: an analysis of their morphology, setting and behaviour. Marine Geology 213, 343362.

Hurrell, J.W., 1995. Decadal trends in the North Atlantic Oscillation: Regional temperatures and precipitation. Science 269, 676-679.

Hurrell, J.W., Delworth, T.L., Danabasoglu, G., Drange, H., Drinkwater, K., Griffies, S., Holbrook, N.J., Kirtman, B., Keenlyside, N., Latif, M., Marotzke, J., Murphy, J., Meehl, G.A., Palmer, T., Pohlmann, H., Rosati, T., Seager, R., Smith, D., Sutton, R., Timmermann, A., Trenberth, K.E., Tribbia, J., Visbeck, M., 2010 Decadal Climate Prediction: Opportunities and Challenges. In Hall, J., Harrison D.E. Stammer, D. (Eds.), Proceedings of the OceanObs'09: Sustained Ocean. Observations and Information for Society conference 2, Venice, Italy, 21-25 September 2009, ESA Publication WPP-306.

Hurrell, J.W., Kushnir, Y., Ottersen, G., Visbeck, M. (Eds.), 2003. The North Atlantic Oscillation: Climate significance and environmental impact. Geophysical 
Monograph Series, American Geophysical Union, Washington, DC, 2003, pp. 135.

Huthnance, J.M., Holt, J.T., Wakelin, S.L., Deep ocean exchange with west-European shelf seas. Ocean Sci. 5, 621-634.

Hustoft, S., Bünz, S., Mienert, J., Chand, S., 2009. Gas hydrate reservoir and active methaneventing province in sediments on $<20$ Ma young oceanic crust in the Fram Strait, offshore NW-Svalbard. Earth and Planetary Science Letters, doi:10.1016/j.epsl.2009.03.038.

Iglesias-Rodríguez, M.D., Halloran, P.R., Rickaby, R.E.M., Hall, I.R., Colmenero- Hidalgo, E., Gittins, J.R., Green, D.R.H., Tyrrell, T., Gibbs, S.J., von Dassow, P., Rehm, E., Armbrust, E.V., Boessenkool, K.P., 2008. Phytoplankton calcification in a high $\mathrm{CO}_{2}$ world. Science 320, 336-339.

Ilyina, T., Zeebe, R.E., Maier-Reimer, E., Heinze, C., 2009. Early detection of ocean acidification effects on marine calcification. Global Biogeochemical Cycles 23, doi:10.1029/2008GB003278

IPCC, 2007a. Climate change 2007: The physical science basis. Contribution of Working Group I to the Fourth Assessment Report of the Intergovernmental Panel on Climate Change. Solomon, S., Qin, D., Manning, M., Chen, Z., Marquis, M., Averyt, K.B., Tignor, M., Miller, H.L. (Eds.) Cambridge University Press, Cambridge, United Kingdom.

IPCC, 2007b. Climate Change 2007: Impacts, Adaption and Vulnerability. Contribution of Working Group II to the Fourth Assessment Report of the Intergovernmental Panel on Climate Change. M.L. Parry, O.F. Canziani, J.P. Palutikof, P.J. van der Linden and C.E. Hanson (Eds.) Cambridge University Press, Cambridge, United Kingdom.

Jayne, S.R., Marotzke, J., 2001. The dynamics of ocean heat transport variability. Reviews of Geophysics 39, 385-411.

Jensen, F.H., Bejder, L., Wahlberg, M., Aguilar Soto, N., Johnson, M., Madsen, P.T., 2009. Vessel noise effects on delphinid communication. Mar. Ecol. Prog. Ser. 395, 161175.

Jickells, T.D., Spokes, L.J., 2001. Atmospheric iron inputs to the oceans. In: The biogeochemistry of iron in seawater. D. R. Turner, K. Hunter, (Eds.), Wiley, Chichester, UK, pp. 85-121.

Jickells, T.D., An, Z.S., Anderson, K.K., Baker, A.R., Bergametti, G., Brooks, N., Cao, J.J., Boyd, P.W., Duce, R.A., Hunter, K.A., Kawahata, H., Kubilay, N., laRoche, J., Liss, P.S., Mahowald, N., Prospero, J.M., Ridgwell, A.J., Tegen, I., Torres, R., 2005. Global iron connections between desert dust, ocean biogeochemistry, and climate. Science 308, 67-71.

Johnson, G.C., Doney, S.C., 2006. Recent western South Atlantic bottom water warming. Geophysical Research Letters 33, 14, L14614, doi.10.1029/2006GL026769.

Johnson, G. C., Mecking, S., Sloyan, B.M., Wijffels, S.E., 2007. Recent bottom water warming in the Pacific Ocean. J. Climate 20, 5365-5375.

Johnson, G.C., Purkey, S.G., Bullister, J.L., 2008. Warming and freshening in the abyssal southeastern Indian Ocean. J. Climate 21, 5351-5363.

Johnson, N.A., Campbell, J.W., Moore, T.S., Rex, M.A., Etter, R.J., McClain, C.R., Dowell, M.D., 2007. The relationship between the standing stock of deep-sea macrobenthos and surface production in the western North Atlantic. Deep-Sea Research I 54, 1350-1360.

Josey, S.A., Grist, J.P, Marsh, R., 2009.Estimates of meridional overturning from surface density flux fields. Journal of Geophysical Research 114, C09022. 
Joyce, T.M., Deser, C., Spall, M.A., 2000. The relation between decadal variability of Subtropical Mode Water and the North Atlantic Oscillation. Journal of Climate 13, 2550-2569.

Judd, A.G., Hovland, M., Dimitrov, L.I., García Gil, S., Jukes, V., 2002. The geological methane budget at continental margins and its influence on climate change. Geofluids 2, 109-126.

Kanamori, H., 2005. Real-time seismology and earthquake damage mitigation. Annual Review of Earth and Planetary Sciences 33, 195-214.

Kanzow, T., Cunningham, S.A., Rayner, D., Hirschi, J.J.-M., Johns, W.E., Baringer, M.O., Bryden, H.L., Beal, L.M., Meinen, C.S., Marotzke, J., 2007. Observed flow compensation associated with the MOC at $26.5^{\circ} \mathrm{N}$ in the Atlantic. Science 317, 938-941.

Kanzow, T., Send, U., McCartney, M., 2008. On the variability of the deep meridional transports in the tropical North Atlantic. Deep-Sea Research I 55, 1601-1623.

Karl, D.M., 2007. Microbial oceanography: paradigms, processes and promise. Nature Reviews 5, 759-769.

Karstensen, J., Schlosser, P., Wallace, D., Bullister, J., Blindheim, J., 2005, Water mass transformation in the Greenland Sea during the 1990s, Journal of Geophysical Research 110, C07022, doi:10.1029/2004JC002510.

Karstensen, J., Stramma, L., Visbeck M., 2008. Oxygen minimum zones in the eastern tropical Atlantic and Pacific oceans. Progress in Oceanography 77, 331-350.

Kawano T., Fukasawa, M., Kouketsu, S., Uchida, H., Doi, T., Kaneko, I., Aoyama, M., Schneider, W., 2006. Bottom water warming along the pathway of Lower Circumpolar Deep Water in the Pacific Ocean. Geophys. Res. Lett. 33, L23613, doi:10.1029/2006GL027933.

Kennett, J.P., Cannariato, K.G., Hendy, I.L, Behl, R.J., 2000. Carbon isotopic evidence for methane hydrate instability during Quaternary interstadials. Science 288, 128-133.

Kahru, M., Mitchell, B.G., 2002. Influence of the El Niño - La Niña cycle on satellite-derived primary production in the California Current. Geophysical Research Letters 29, doi:10.1029/2002GL014963.

Kessler, J.D., Reeburgh, W.S., Southon, J., Seifert, R., Michaelis, W., Tyler, S.C., 2006. Basin-wide estimates of the input of methane from seeps and the clathrates to the Black Sea. Earth and Planetary Science Letters 243, 366-375.

Killworth, P.D., 2008. A simple linear model of the depth dependence of the wind-driven variability of the Meridional Overturning Circulation. Journal of Physical Oceanography 38, 492-502

Koeller, P., Fuentes-Yaco, C., Platt, T., Sathyendranath, S., Richards, A., Ouellet, P., Orr, D., Skúladóttir, U., Wieland, K., Savard, L., Aschan, M., 2009. Basin-scale coherence in phenology of shrimps and phytoplankton in the North Atlantic Ocean. Science 324, 791-793.

Krom, M.D., Brenner, S., Kress, N., Gordon, L.I., 1991. Phosphorus limitation of primary productivity in the E. Mediterranean sea. Limnol. Oceanog. 36, 424-432.

Krom, M.D. Emeis, K.-C., Van Cappellen, P., 2010. Why is the Eastern Mediterranean phosphorus limited? Prog. Oceanog. 85, 236-244.

Körtzinger, A., Send, U., Lampitt, R.S., Hartman, S., Wallace, D.W.R., Karstensen, J., Villagarcia, M.G., Llinás, O., DeGrandpre, M.D., 2008. The seasonal $p \mathrm{CO}_{2}$ cycle at $49^{\circ} \mathrm{N} / 16.5^{\circ} \mathrm{W}$ in the northeastern Atlantic Ocean and what it tells us about biological productivity. Journal of Geophysical Research 113, doi:10.1029/2007JC004347. 
Kreemer, C., Holt, W.E., Haines, A.J., 2003. An integrated global model of present-day plate motions and plate boundary deformation. Geophysical Journal International 154, 8-34.

Kuhlbrodt, T., Griesel, A., Montoya, M., Levermann, A., Hofmann, M., Rahmstorf S., 2007. On the driving processes of the Atlantic meridional overturning circulation, Reviews of Geophysics 45, RG2001, doi:10.1029/2004RG000166.

Lampitt, R.S., Achterberg, E.P., Anderson, T.R., Hughes, J.A., Iglesias-Rodriguez, M.D., Kelly-Gerreyn, B.A., Lucas, M., Popova, E.E., Sanders, R., Shepherd, J.G., Smythe-Wright, D.,Yool, A., 2008. Ocean fertilization: a potential means of geoengineering? Philosophical Transactions of the Royal Society of London A, 366, 3919-3945.

Lampitt, R.S., Antia, A.N., 1997.Particle flux in deep seas: regional characteristics and temporal variability. Deep-Sea Research I 44, pp. 1377-1403.

Lampitt, R.S., Salter, I., de Cuevas, B., Hartman, S., Larkin, K., Peabody, C.A., 2010. Longterm variability of downward particle flux in the deep northeast Atlantic: Causes and trends. Deep-Sea Research II 57, 1346-1361.

Lampitt, R.S., Favali, P., Barnes, C.R., Church, M.J., Cronin, M.F., Hill, K.L., Kaneda, Y., Karl, D.M., Knap, A.H., McPhaden, M.J., Nittis, K.A., Priede, I.G., Rolin, J-F., Send, U., Teng, C.-C., Trull, T.W., Wallace, D.W.R., Weller, R.A., 2010. In Situ Sustained Eulerian Observatories. In Hall, J., Harrison D.E. Stammer, D. (Eds.), Proceedings of the OceanObs'09: Sustained Ocean. Observations and Information for Society conference 2, Venice, Italy, 21-25 September 2009, ESA Publication WPP-306.

Langer, G., Geisen, M., Baumann, K.H., Kläs, J., Riebesell, U., Thoms, S., Young, J.R., 2006. Species-specific responses of calcifying algae to changing seawater carbonate chemistry. Geochemistry, Geophysics, Geosystems 7, doi: 10.1029/2005GC001227.

Lastras, G., Arzola, R.G., Masson, D.G., Wynn, R.B., Huvenne, V.A.I., Hühnerbach, V., Canals M., 2009. Geomorphology and sedimentary features in the Central Portuguese submarine canyons. Western Iberian margin, Geomorphology 103, 310-329.

Lauderdale, J.M., Bacon, S., Naveira Garabato, A.C., Holliday, N.P., 2008. Intensified turbulent mixing in the boundary current system of southern Greenland. Geophysical Research Letters 35, doi:10.1029/2007GL032785.

Lavaleye, M., Duineveld, G., Lundälv, T., White, M., Guihen, D.,Kiriakoulakis, K., Wolff, G.A., 2009. Cold-water corals on the Tisler Reef: Preliminary observations on the dynamic reef environment. Oceanography 22, 54-62.

Laws, E.A., 2004. Export flux and stability as regulators of community composition in pelagic marine biological communities: Implications for regime shifts. Progress in Oceanography 60, 343-354.

Lay, T., Kanamori, H., Ammon, C.J., Nettles, M., Ward, S.N., Aster, R.C., Beck, S.L., Bilek, S.L., Brudzinski, M.R., Butler, R., DeShon, H.R., Ekström, G., Satake, K., Sipkin, S., 2005.The great Sumatra-Andaman earthquake of 26 December 2004. Science 308, 1127-1133.

Lecointre, A., Penduff, T., Cipollini, P., Tailleux, R., Barnier, B., 2008. Depth dependence of westward-propagating North Atlantic features diagnosed from altimetry and a numerical 1/6 model. Ocean Science 4, 99-113.

Lessard, E.J., Merico, A., Tyrrell, T. 2005. Nitrate:phosphate ratios and Emiliania huxleyi blooms. Limnol. Oceanogr. 50: 1020-1024. 
Leynaud, D., Mienert, J., Vanneste, M., 2008. Submarine mass movements on glaciated and non-glaciated European continental margins: A review of triggering mechanisms and preconditions to failure. Marine and Petroleum Geology, doi:10.1016/j.marpetgeo.2008.02.008.

Levin, L., Etter, R.J., Rex, M.A., Gooday, A.J., Smith, C.R., Pineda, J., Stuart, C.T., Hessler, R.R., Pawson, D., 2001. Environmental influences on regional deep-sea species diversity. Annual Review of Ecology and Systematics 32, 51-93.

Levitus, S., Antonov, J.I., Boyer, T.P., Stephens, C., 2000. Warming of the World Ocean. Science 287, 2225- 2229.

Lichtschlag, A; Felden, J; Bruchert, V, Boetius, A., de Beer, D., 2010. Geochemical processes and chemosynthetic primary production in different thiotrophic mats of the Hakon Mosby Mud Volcano (Barents Sea). Limnol. Oceanog. 55, 931-949.

Locat, J., Mienert, J., Boisvert, L. (Eds) 2003. Submarine mass movements and their consequences: 1st international symposium. Kluwer Academic Publishers, Dordrecht, Boston.

Lomax, A., Michelini, A., Piatanesi A., 2007. An energy-duration procedure for rapid determination of earthquake magnitude and tsunamigenic potential. Geophysical Journal International 170, 1195-1209.

Longhurst, A., 2006. Ecological geography of the sea. San Diego, CA. Academic Press. 560pp.

Lorito, S., Tiberti, M.M., Basili, R., Piatanesi, A., Valensise, G., 2008. Earthquake-generated tsunamis in the Mediterranean Sea: Scenarios of potential threats to Southern Italy. Journal of Geophysical Research 113, doi:10.1029/2007JB004943.

Lutz, M., Dunbar, R., Caldeira, K., 2002. Regional variability in the vertical flux of particulate organic carbon in the ocean interior. Global Biogeochemical Cycles 16, doi:10.1029/2000GB001383.

Lykousis V., Sakellariou, D., Moretti, I., Kaberi, H., 2007. Late Quaternary basin evolution of the Gulf of Corinth: Sequence stratigraphy, sedimentation, fault-slip and subsidence rates. Tectonophysics 440, 29-51.

Lykousis, V., Alexandri, S., Woodside, J., de Lange, G., Dählmann, A., Perissoratis, C., Heeschen, K., Ioakim, Chr., Sakellariou, D., Nomikou, P., Rousakis, G., Casas, D., Ballas, D., Ercilla, G., 2009. Mud volcanoes and gas hydrates in the Anaximander mountains (Eastern Mediterranean Sea). Marine and Petroleum Geology 26, 854-872.

Mantovani, E., Viti, M., Babbucci, D., Albarello, D., 2007. Nubia-Eurasia kinematics: An alternative interpretation from Mediterranean and North Atlantic evidence. Annals of Geophysics 50, 341-366.

Mari, X., 2008. Does ocean acidification induce an upward flux of marine aggregates? Biogeosciences 5, 1023-1031.

Marinaro, G., Etiope G., Lo Bue, N., Favali, P., Papatheodorou, G., Christodoulou, D., Furlan, F., Gasparoni, F., Ferentinos, G., Masson, M., Rolin, J.-F., 2006. Monitoring of a methane-seeping pockmark by cabled benthic observatory (Patras Gulf, Greece). Geo-Marine Letters 26, doi: 10.1007/s00367-006-0040-4.

Marinov, I., Gnanadesikan, A., Sarmiento, J.L., Toggweiler, J.R., Follows, M., Mignone, B. K., 2008. Impact of oceanic circulation on biological carbon storage in the ocean and atmospheric $\mathrm{pCO}_{2}$. Global Biogoecheical Cycles 22, doi:10.1029/2007GB002958.

Martin, J.H., Fitzwater, S.E., 1988. Iron-deficiency limits phytoplankton growth in the northeast Pacific subarctic. Nature 331, 341-343. 
Marzeion, B., Levermann, A., Mignot, J., 2010. Sensitivity of North Atlantic subpolar gyre and overturning to stratification-dependent mixing: response to global warming. Climate Dynamics 34, 661-668.

Matsumoto, K., 2007. Radiocarbon-based circulation age of the world oceans. Journal of Geophysical Research 112, C09004, doi:10.1029/2007JC004095.

Maynou, F., 2008. Influence of the North Atlantic Oscillation on Mediterranean deep-sea shrimp landings. Climate Research 36, 253-257.

McCauley, R.D., Fewtrell, J., Duncan, A.J., Jenner, M.-N., Penrose, J.D., Prince, R.I.T., Adhitya, A., Murdoch, J., McCabe, C., 2000. Marine seismic surveys: Analysis and propagation of air gun signals; and effects of air-gun exposure on Humpback whales, sea turtles, fishes and squid. - Prepared for The Australian Petroleum Production and Exploration Association. Project CMST 163, Report R99-15, Curtin University of Technology. Perth, Australia.

MCCIP, 2010. Marine Climate Change Impacts Annual Report Card 2010-2011. (Eds. Baxter JM, Buckley PJ Wallace CJ), Summary Report, MCCIP, Lowestoft, 12pp.

McGillicuddy, D.J., Jr., Anderson, L.A., Bates, N.R., Bibby, T., Buesseler, K.O., Carlson, C.A., Davis, C.S., Ewart, C., Falkowski, P.G., Goldthwait, S.A., Hansell, D.A., Jenkins, W.J., Johnson, R., Kosnyrev, V.K., Ledwell, J.R., Li, Q.P., Siegel, D.A., Steinberg, D.K., 2007. Eddy/wind interactions stimulate extraordinary mid-ocean plankton blooms. Science 315, 1021-1026.

McGinnis, D.F., Greinert, J., Artemov, Y., Beaubien, S.E., Wüest A., 2006. Fate of rising methane bubbles in stratified waters: How much methane reaches the atmosphere? Journal of Geophysical Research 111, C09007, doi:10.1029/2005JC003183.

McGowan, J.A., Cayan, D.R., Dorman, L M., 1998. Climate-ocean variability and ecosystem response in the North Pacific Ocean. Science 281, 210-217.

McPhaden, M.J., Picaut, J., 1990 Zonal displacement of the western Pacific warm pool associated with the 1986-87 ENSO event. Science 250, 1385-1388.

Meinig, C., Stalin, S.E., Nakamura, A.I., Gonzalez, F., Milburn, H.B., 2005. Technology developments in real-time tsunami measuring, monitoring and forecasting. in: OCEANS, 2005. Proceedings of MTS/IEEE: 1673-1679, Vol. 2, ISBN: 0-93395734-3.

Mete Uz, B., Yoder, J.A., Osychny, V., 2001. Pumping of nutrients to ocean surface waters by the action of propagating planetary waves. Nature 409, 597-600.

Mezić, I., Loire, S., Fonoberov, V.A., Hogan, P., 2010. A New Mixing Diagnostic and Gulf Oil Spill Movement Science 330, 486 - 489

Micallef, A., Berndt, C., Masson, D.G., Stow D.A.V., 2008. Scale invariant characteristics of the Storegga Slide and implications for large-scale submarine mass movements. Marine Geology 247, 46-60.

Mienert, J., 2004. COSTA - continental slope stability: major aims and topics. Marine Geology 213, 1-7.

Mienert, J., Weaver, P.P.W., Berne, S., Dullo, C, Evans, D., Freiwald, A., Henriet, J.-P., Joergensen, B.B., Lericolais, G., Lykousis, V., Parkes, J., Trincardi, F., Westbrook, G., 2004. Overview of recent, ongoing, and future investigations on the dynamics and evolution of European margins. Oceanography 17, 16-33.

Mienert, J., Andreassen, K., Posewang, J., Lukas, D., 2000. Changes of the hydrate stability zone of the Norwegian margin from glacial to interglacial times. Annals of the New York Academy of Sciences 912, 200-210.

Migneco, E., Aiello, S., Aloisio, A., Ameli, F., Amore, I., Anghinolfi, M., Anzalone, A., Barbarino, G., Barbarito, E., Battaglieri, M., Bazzotti, M., Bellotti, R., Bersani, A., Beverini, N., Biagil, S., Bonori, M., Bouhdaef, B., Brescia, M., Cacopardo, G., 
Calì, C., Capone, A., Caponettom, L., Carminatil, G., Cassano, B.,Castorina, E., Ceres, A., Chiarusi, T., Circella, M., Cocimano, R., Coniglione, R., Cordelli, M., Costa, M., D’Amico, A., D’Amato, C., D’Amato, V., De Bonis, G., De Rosa, G., De Ruvo, G., De Vita, R., Distefano, C., Falchini, E., Flaminio, V., Fratini, K., Gabrielli, A., Galeotti, S., Gandolfi, E., Giacomelli, G., Giorgi, F., Giovanetti, G., Grimaldi, A., Grmek, A., Habel, R., Leonora, E., Lonardo, A., Longo, G., Lo Presti, D., Lucarelli, F., Maccione, L., Margiotta, A., Martini, A., Masullo, R., Maugeri, F., Megna, R., Minutoli, S., Mongelli, M., Montaruli, T., Morganti, M., Musico, P., Musumeci, M., Nicolau, C.A., Orlando, A., Osipenko, M., Osteria, G., Papaleo, R., Pappalardo, V., Petta, C., Piattelli, P., Piombo, D., Raia, G., Randazzo, N., Reito, S., Ricco, G., Riccobene, G., Ripani, M., Rovelli, A., Ruppi, M., Russo, G.V., Russo, S., Sapienza, P., Sedita, M., Shirokov, E., Simeone, F., Sipala, V., Sollima, C., Speziale, F., Spurio, M., Taiuti, M., Terreni, G., Trasatti, L., Urso, S., Valente, V., Vecchi, M., Vicini, P., Wischnewski, R., 2008. Status of the NEMO project, Nuclear Instruments and Methods in Physics Research Section A: Accelerators, Spectrometers, Detectors and Associated Equipment, A588, 111-118.

Migneco, E., Capone, A., Piattelli, P., 2006. Underwater laboratories for astroparticle physics and deep-sea science. Annals of Geophysics 49, 2/3:643-658.

Millot, C., Candela, J., Fuda, J.-L., Tber, Y., 2006. Large warming and salinification of the Mediterranean outflow due to changes in its composition. Deep-Sea Research I 53, 656-666.

Mills, M.M., Moore, C.M., Langlois, R., Milne, A., Achterberg, E.P., Nachtigall, K., Lochte, K., Geider, R.J., La Roche, J., 2008. Nitrogen and phosphorus co-limitation of bacterial productivity and growth in the oligotrophic subtropical North Atlantic. Limnology and Oceanography 53, 824-834.

Mills, M.M., Ridame, C., Davey, M., La Roche, J., Geider, R.J., 2004. Iron and phosphorus co-limit nitrogen fixation in the eastern tropical North Atlantic. Nature 429, 292293.

Miranda, J.M., Luis, J.F., Lourenço, N., Santos, F.M., 2005. Identification of the magnetization low of the Lucky Strike hydrothermal vent using surface magnetic data. Journal of Geophysical Research, 110, B04103.

Marinov, I., Gnanadesikan, A., Sarmiento, J.L., Toggweiler, J.R., Follows, M., Mignone, B.K., 2008. Impact of oceanic circulation on biological carbon storage in the ocean and atmospheric $p \mathrm{CO}_{2}$. Global Biogeochemical Cycles 22 GB3007, doi:10.1029/2007GB002958.

Moore, C.M., Mills, M.M., Langlois, R., Milne, A., Achterberg, E.P., La Roche, J., Geider, R.J., 2008. Relative influence of nitrogen and phosphorous availability on phytoplankton physiology and productivity in the oligotrophic sub-tropical North Atlantic Ocean. Limnology and Oceanography 53, 291-305.

Moran, P.A.P., 1953. The statistical analysis of the Canadian lynx cycle. II. Synchronization and meteorology. Australian Journal of Zoology 1, 291-298.

Morato, T., Pitcher, T.J., Clark, M.R., Menezes, G., Tempera, F., Porteiro, F., Giacomello, E., Santos, R.S., 2010. Can we protect seamount for research? A call for conservation. Oceanography, 23, 190-199.

Munk, W., Wunsch C., 1998. Abyssal recipes II. Deep-Sea Research 45, 1976-2009.

National Research Council (NRC), 2000. Illuminating the hidden planet. The future of seafloor observatory science. National Academy Press, Washington, DC., 135 pp. 
Nellemann, C., Hain, S., Alder, J. (Eds), 2008. In dead water - merging of climate change with pollution, over-harvest, and infestations in the world's fishing grounds. United Nations Environment Programme, GRID-Arendal, Norway.

Neuer, S., Cianca, A. Helmke, P. Freudenthal, T. Davenport, R. Meggers, H. Knoll, M. Santana-Casiano, J.M. González-Davila, M. Rueda, M.-J. Llinás, O., 2007. Biogeochemistry and hydrography in the eastern subtropical North Atlantic gyre. Results from the European time-series station ESTOC. Prog. Oceanog. 72, 1-29.

Nelson, N.B., Siegel, D.A., Carlson, C.A., Swan, C., Smethie, W.M., Jr., Khatiwala, S., 2007. Hydrography of chromophoric dissolved organic matter in the North Atlantic. Deep-Sea Research I 54, 710-731.

Nielsdóttir, M.C., Moore, C.M., Sanders, R., Hinz, D.J., Achterberg, E.P., 2009. Iron limitation of the postbloom phytoplankton communities in the Iceland Basin. Global Biogeochemical Cycles 23, doi:10.1029/2008GB003410.

Niemann, H., Lösekann, T., de Beer, D., Elvert, M., Nadalig, T., Knittel, K., Amann, R., Sauter, E. J., Schlüter, M., Klages, M., Foucher, J.P., Boetius, A., 2006a. Novel microbial communities of the Haakon Mosby mud volcano and their role as a methane sink. Nature 443, 854-858.

Niemann, H., Duarte, J., Hensen, C., Omoregie, E., Magalhães, V.H., Elvert, M., Pinheiro, L.M., Kopf, A., Boetius, A., 2006b. Microbial methane turnover at mud volcanoes of the Gulf of Cadiz. Geochimica et Cosmochimica Acta 70, 5336-5355.

Nuzzo M., Hornibrook, E.R.C., Hensen, C., Parkes, R.J., Cragg, B.A., Rinna, J., von Deimling, J.S., Stommer, S., Magalhães, V.H., Reitz, A., Brückmann, W., Pinheiro, L.M., 2008. Shallow microbial recycling of deep-sourced carbon in Gulf of Cadiz mud volcanoes. Geomicrobiology Journal 25, 283-295.

Olivieri, M., Scognamiglio, L., 2007.Toward a Euro Mediterranean tsunami warning system: The case of the February 12, 2007, Ml = 6.1 earthquake, Geophysical Research Letters, 34, doi:10.1029/2007GL031364.

Olu-Le, R.K., Sibuet, M., Fiala-Medioni, A., Gofas, S., Salas, C., Mariotti, A., Foucher, J.P., Woodside, J., 2004. Cold seep communities in the deep eastern Mediterranean Sea: composition, symbiosis and spatial distribution on mud volcanoes. Deep-Sea Research I 51, 1915-1936.

Orr, J.C., Fabry, V.J. Aumont, O., Bopp, L., Doney, S.C., Feely, R.A., Gnanadesikan, A., Gruber, N., Ishida, A., Joos, F., Key, R.M., Lindsay, K., Maier-Reimer, E., Matear, R, Monfray, P., Mouchet, A., Najjar, R.G., Platter, G.-K., Rodgers, K.B., Sabine, C.L., Sarmiento, J.L., Schiltzer, R., Salter, R., Totterdell, I.J., Weirig, M.F., Yamanka, Y., Yool, A., 2005. Anthropogenic ocean acidification over the twenty-first century and its impact on marine calcifying organisms. Nature 437, 681-686.

Østerhus, S., Gammelsrød, T., 1999. The abyss of the Nordic Seas is warming. Journal of Climate 12, 3297-3304.

Pace, M.L., Knauer, G.A., Karl, D.M., Martin, J.H., 1987. Primary production, new production and vertical flux in the eastern Pacific Ocean. Nature 325, 803-803.

Palmer, M.D., Haines, K., Tett, S.F.B., Ansell, T.J., 2007. Isolating the signal of ocean global warming. Geophysical Research Letters 34, doi:10.1029/2007GL031712.

Palter, J.B., Lozier, M.S., Barber, R.T., 2005. The effect of advection on the nutrient reservoir in the North Atlantic subtropical gyre. Nature 437, 687-692.

Parsons, T., 2004. Recalculated probability of $M>7$ earthquakes beneath the Sea of Marmara. Journal of Geophysical Research 109, doi:10.1029/2003JB002667.

Parsons, L.S., Lear, W.H., 2001. Climate variability and marine ecosystem impacts: a North Atlantic Perspective. Progress in Oceanography 49, 167-188. 
Parsons, T.S., Toda T.S., Stein R.S., Barka, A., Dietrich, J.H., 2000. Heightened odds of large earthquakes near Istanbul, An interaction-based probability calculation. Science 288, 661-665.

Paul, J., Scholin, C., van den Engh, G., Perry, M.J., 2007. In situ Instrumentation. Oceanography 20, 58-66.

Paull, C.K., Schlining, B., Ussler, W., III, Paduan, J.B., Caress, D., Greene, H.G., 2005. Distribution of chemosynthetic biological communities in Monterey Bay, California. Geology 33, 85-88.

Paull, C.K., Jull, A.J.T., Toolin, L.J., Linick, T., 1985. Stable isotope evidence for chemosynthesis in and abyssal seep community. Nature 317, 708-711.

Payton, P., Mackey, K.R.M., Chen, Y., Lima, I.D., Doney, S.C., Mahowald, N., Labiosa, R., Post, A., 2009. Toxicity of atmospheric aerosols on marine phytoplankton. Proceedings of the National Academy of Sciences USA 106, 4601-4605.

Pfannkuche, O., Boetius, A., Lochte, K., Lundgreen, U., Thiel, H., 1999. Responses of deepsea benthos to sedimentation patterns in the North-East Atlantic in 1992. DeepSea Research I 46, 573-596.

Pfannkuche, O., Lochte, K., 1993. Open ocean pelago-benthic coupling: cyanobacteria as tracers of sedimenting salp faeces. Deep-Sea Research I 40, 727-737.

Piatanesi, A., Tinti, S., 1998. A revision of the 1693 eastern Sicily earthquake and tsunami. Journal of Geophysical Research 103, B2, 2749-2758.

Pickart, R.S., Spall, M., Ribergaard, M.H., Moore, G.W.K., Milliff R., 2003. Deep convection in the Irminger Sea forced by the Greenland tip jet. Nature 424, 152-156.

Pierce, D.W., 2004. Future changes in biological activity in the North Pacific due to anthropogenic forcing of the physical environment. Climate Change 62, 389-418.

Piontkovski, S.A., O’Brien, T., Umani, S.F., Krupa, E.G., Stuge, T S., Balymbetov, K., Grishaeva, O.V., Kasymov, A.G., 2006. Zooplankton and the North Atlantic Oscillation: a basin-scale analysis. Journal of Plankton Research 28, 1039-1046.

Polzin, K.L., Toole, J.M., Ledwell, J.R., Schmitt, R.W., 1997. Spatial variability of turbulent mixing in the abyssal ocean. Science 276, 93-96.

Potter, J.R., Delory, E., 1998. Noise sources in the sea and the impact for those who live there. Acoustics and Vibrations, Asia' 98, Singapore.

Priede, I.G., Mienert, J., Person, R., van Weering, T.C.E., Pfannkuche, O., O’Neill, N., Tselepides, A., Thompson, L., Favali, P., Gasparioni, F., Zitellini, N., Millot, C., Gerber, H.W., Miranda, J.M.A., 2003. ESONET- European Sea Floor Observatory Network. In: H. Dahlin, N.C., Fleming, K., Nittis, Petersson, S.E., (Eds.) Building the European capacity in operational oceanography. Elsevier Oceanography Series 69. Elsevier, Amsterdam, pp. 291-294.

Priede, I.G., Person, R., Favali, P., 2005. European Seafloor Observatory Network. Sea Technology 46, 45-49.

Proskurowski, G., Lilley, M.D., Seewald, J.S., Früh-Green, G.L., Olson, E.J., Lupton, J. E., Sylva, S.P., Kelley, D.S., 2008. Abiogenic hydrocarbon production at Lost City hydrothermal field. Science 319, 604-607.

Puillat, I., Taupier-Letage, I., Millot C., 2002. Algerian eddies lifetime can near 3 years. Journal of Marine Systems 31, 245- 259.

Pugh, D., 2008. Socio-economic indicators of marine activities in the UK Economy. The Crown Estate, 68pp.

Raven, J., Caldeira, K., Elderfield, H., Hoegh-Guldberg, O., Liss, P., Riebesell, U., Shepherd, J., Turley, C., Watson, A., 2005. Ocean acidification due to increasing atmospheric carbon dioxide. Royal Society, London. pp. 60. 
Rex, M.A., Etter, R.J., Morris, J.S., Crouse, J., McClain, C.R., Johnson, N.A., Stuart, C.T., Deming, J.W., Thies, R., Avery, R., 2006. Global bathymetric patterns of standing stock and body size in the deep-sea benthos. Marine Ecology Progress Series 317, $1-8$.

Rhines, P., 2006. Sub-Arctic oceans and global climate. Weather 61, 109-118.

Rhines, P., Häkkinen, S., Josey, S.A., 2008. Is oceanic heat transport significant in the climate system? In: R.R. Dickson et al. (Eds.), Arctic-Subarctic Ocean Fluxes, 87-109.

Richardson, A.J., 2008. In hot water: zooplankton and climate change. ICES Journal of Marine Science 65, 279-295.

Richardson, A.J., Schoeman, D.S., 2004. Climate impact on plankton ecosystems in the Northeast Atlantic. Science 305, 1609-1612.

Richardson, T.L., Jackson, G.A., 2007. Small phytoplankton and carbon export from the surface ocean. Science 315, 838-840.

Richardson, W.J., Malme, C.I., Green, C.R., Jr., Thomson, D.H., 1995. Marine mammals and noise. Academic Press, San Diego.

Riebesell, U., Zondervan, I., Rost, B., Tortell, P.D., Zeebe, R.E., Morel, F.M.M., 2000. Reduced calcification in marine plankton in response to increased atmospheric $\mathrm{CO}_{2}$. Nature 407, 634-637.

Rigaud, V., Semac, D., Nokin, M., DESIBEL Team, Tietze, G., Hamann, H., Goetz, V., Pascoal, A., 1998. New methods for Deep-Sea Intervention on future Benthic Laboratories, DESIBEL Project-Final Results, Comparison of concepts and at sea validation. Proceedings of the IEEE Conference OCEANS '98.

Rijkenberg, M.J.A., Powell, C.F., Dall'Osto, M., Nielsdottir, M.C., Patey, M.D., Hill, P.G., Baker, A.R., Jickells, T.D., Harrison, R.M., Achterberg, E.P., 2008. Changes in iron speciation following a Saharan dust event in the tropical North Atlantic Ocean. Marine Chemistry 110, 56-67.

Rintoul, S.R., Balmeseda, M., Cunningham, S., Dushaw, B.D., Garzoli, S., Gordon, A., Heimbach, P., Hood, M., Johnson, G., Latif, M., Send, U., Shum, C., Speich, S., Stammer, D., 2010. Deep circulation and meridional overturning: Recent progress and a strategy for sustained obervations. In Hall, J., Harrison D.E. Stammer, D. (Eds.), Proceedings of the OceanObs'09: Sustained Ocean. Observations and Information for Society conference 2, Venice, Italy, 21-25 September 2009, ESA Publication WPP-306.

Riou, V.; Colaço, A., Bouillon, S., Khripounoff, A., Dando, P.; Mangion, P., Chevalier, E.; Korntheuer, M., Serrão Santos, R., Dehairs, F. ,2010. The mixotrophic side of the deep sea hydrothermal, dual endosymbiotic, mytilid Bathymodiolus azoricus: assimilation of dissolved and particulate organic matter. Marine Ecology Progress Series 405, 187-201.

Riser, S.C., Johnson, K.S., 2008. Net production of oxygen in the subtropical ocean. Nature 451, 323-325.

Roberts, J.M., Davies, A.J., Henry, L.A., Dodds, L.A., Duineveld, G.C.A., Lavaleye, M.S.S., Maier, C., van Soest, R.W.M., Bergman, M.J.N., Huehnerbach, V., Huvenne, V.A.I., Sinclair, D. J., Watmough, T., Long, D., Green, S.L., van Haren, H., 2009. Mingulay reef complex: an interdisciplinary study of cold-water coral habitat, hydrography and biodiversity. Mar. Ecol. Prog. Ser. 397, 139-151.

Roberts, J.M., Wheeler, A.J., Freiwald, A., 2006. Reefs of the deep: The biology and geology of cold-water coral ecosystems. Science 312, 543-547.

Robidart, J.C., Bench, S.R., Feldman, R.A., Novoradovsky, A., Podell, S.B., Gaasterland, T., Allen, E.E., Felbeck, H., 2008. Metabolic versatility of the Riftia pachyptila 
endosymbiont revealed through metagenomics. Environmental Microbiology 10, 727-737.

Robinson, C., Steinberg, D.K., Anderson, T.R., Aristegui, J., Carlson, C.A., Frost, J.R., Ghiglione, J.-F., Hernandez-Leon, S., Jackson, G.A., Koppelmann, R., Queguiner, B., Ragueneau, O., Rassoulzadegan, F., Robison, B.H., Tamburini, C., Tanaka, T, Wishner, K.F., Zhang, J., 2010. Mesopelagic zone ecology and biogeochemistry a synthesis. Deep-Sea Research II 57, 1504-1518.

Robison, B.H., Reisenbichler, K.R., Sherlock R.E., 2005. Giant larvacean houses: rapid carbon transport to the deep sea floor. Science 308, 1609-1611.

Rodwell, M.J., Rowell, D.P., Folland, C.K., 1999. Oceanic forcing of the wintertime North Atlantic Oscillation and European climate. Nature, 398, 320-323.

Roemmich, D., Owens, W.B., 2000. The Argo Project: global ocean observations for understanding and prediction of climate variability. Oceanography 13, 45-50.

Rohwer, F., Thurber, R.V. 2009. Viruses manipulate the marine environment. Nature 459, 207-212.

Rosenzweig, C., Karoly, D., Vicarelli, M., Neofotis, P., Wu, Q., Casassa, G., Menzel, A., Root, T.L., Estrella, N., Seguin, B., Tryjanowski, P., Liu, C., Rawlins, S., Imeson, A., 2008. Attributing physical and biological impacts to anthropogenic climate change. Nature 453, 353-357.

Rowe, G.T., Polloni, P.T., Haedrich, R.L., 1982. The deep-sea macrobenthos on the continental margin of the Northwest Atlantic Ocean. Deep-Sea Research A 29, 257-278.

Royama, T., 2005. Moran effect on nonlinear population processes. Ecological Monographs 75, 277-293.

Ruan, Q.S., Dutta, D., Schwalbach, M.S., Steele, J.A., Fuhrman, J.A., Sun, F., 2006. Local similarity analysis reveals unique associations among marine bacterioplankton species and environmental factors. Bioinformatics 22, 2532-2538.

Ruhl, H.A., 2008. Community change in the variable resource habitat of the abyssal northeast Pacific. Ecology 89, 991-1000.

Ruhl, H.A., Ellena, J.A., Smith, K.L., Jr., 2008. Connections between climate, food limitation, and carbon cycling in abyssal sediment communities. Proceedings of the National Academy of Sciences USA 105, 17006-17011.

Ruhl, H.A, Smith, K.L., Jr., 2004. Shifts in deep-sea community structure linked to climate and food supply. Science 305, 513-515.

Rykaczewski, R.R., Checkley, D.M., 2008. Influence of ocean winds on the pelagic ecosystem in upwelling regions. Proceedings of the National Academy of Sciences USA 105, 1965-1970.

Sabine, C.L., Feely, R.A., Gruber, N., Key, R.M., Lee, K., Bullister, J.L., Wanninkhof, R., Wong, C.S., Wallace, D.W.R., Tilbrook, B., Millero, F.J., Peng, T.-H., Kozyr, A., Ono, T., Rios, A.F., 2004. The oceanic sink for anthropogenic $\mathrm{CO}_{2}$. Science 305, 367-371.

Santana-Casiano, J.M., M. González-Dávila, M.-J. Rueda, O. Llinás, and E.-F. GonzálezDávila, 2007. The interannual variability of oceanic $\mathrm{CO}_{2}$ parameters in the northeast Atlantic subtropical gyre at the ESTOC site. Global Biogeochemical Cycles 21, GB1015, doi:10.1029/2006GB002788.

Santos, A.M.P., Kazmin, A.S., Peliz, Á., 2005. Decadal changes in the Canary upwelling system as revealed by satellite observations: Their impact on productivity. Journal of Marine Research 63, 359-379.

Sarafanov, A.A., 2009. Link of ocean deep water thermohaline anomalies with atmospheric state anomalies in the Northern Atlantic. Oceanology 427, 1047-1050. 
Sarafanov, A., Falina, A., Sokov, A. Demidov, A. 2008. Intense warming and salinification of intermediate waters of southern origin in the eastern subpolar North Atlantic in the 1990s to mid-2000s. Journal of Geophysical Research 113, C12022, doi:10.1029/2008JC004975.

Sarmiento, J.L., Gruber, N, 2006. Ocean biogeochemical dynamics, Princeton University Press, USA, $526 \mathrm{pp}$.

Sarmiento, J.L., Gruber, N., Brzezinski, M.A., Dunne, J.P., 2004. High latitude controls of the global nutricline and low latitude biological productivity. Nature 427, 56-60.

Shaffer, G., 2010. Long-term effectiveness and consequences of carbon dioxide sequestration. Nature Geoscience 3, 464-467.

Scheffer, M., Carpenter, S.R., Foley, J.A., Folke, C., Walker, B., 2001. Catastrophic shifts in ecosystems. Nature 413, 591-596.

Schindler, U., Diepenbroek, M., 2008. Generic XML-based framework for metadata portals. Computers and Geosciences 34, 1947-1955.

Schmale, O., Greinert, J., Rehder, G., 2005. Methane emission from high-intensity marine gas seeps in the Black Sea into the atmosphere. Geophysical Research Letters 32, doi:10.1029/2004GL021138.

Schuster, U., Watson, A., 2007. A variable and decreasing sink for atmospheric $\mathrm{CO}_{2}$ in the North Atlantic. Journal of Geophysical Research 112, doi:10.1029/2006JC003941.

Sedwick, P.N., Sholkovitz, E.R., Church, T.M., 2007. Impact of anthropogenic combustion emissions on the fractional solubility of aerosol iron: Evidence from the Sargasso Sea. Geochemistry, Geophysics, Geosystems 8: Q10Q06, doi:10.1029/2007GC001586.

Sgroi, T., Beranzoli, L., Di Grazia, G., Ursino, A., Favali, P., 2007. New observations of local seismicity by the SN-1 seafloor observatory in the Ionian Sea, off-shore Eastern Sicily (Italy). Geophysical Journal International 169, 490-501.

Shakhova, N., Sergienko, V.I., Semiletov, I., 2009. Modern state of the role of the East Siberian Shelf in the methane cycle, Herald of the Russian Academy of Sciences 3:237-246.

Shepherd, J.G., Working Group on Geoengineering the Climate, 2009. Geoengineering the climate: Science, governance and uncertainty. London, GB, Royal Society, 98pp., (RS Policy document, 10/29).

Siegel, D.A., Deuser, W.G., 1997. Trajectories of sinking particles in the Sargasso Sea: modeling of statistical funnels above deep ocean sediment traps. Deep-Sea Research I 44: 1519-1541.

Siegel, D.A., Doney, S.C., Yoder, J.A., 2002. The North Atlantic spring phytoplankton bloom and Sverdrup's critical depth hypothesis. Science 296, 730-733.

Siegel, D.A., Fields, E., Buesseler, K.O., 2008. A bottom-up view of the biological pump: Modeling source funnels above ocean sediment traps. Deep-Sea Research I 55, 108-127.

Smith, C.R., De Leo, F.C., Bernardo, A.F., Sweetman, A.K., Arbizu, P.M., 2008b. Abyssal food limitation, ecosystem structure and climate change. Trends in Ecology and Evolution 23, 518-528.

Smith, C.R., Berelson, W., Demaster, D.J., Dobbs, F.C., Hammond, D., Hoover, D.J., Pope, R.H., Stephens, M., 1997. Latitudinal variations in benthic processes in the abyssal equatorial Pacific: control by biogenic particle flux. Deep Sea Research II 44, 2295-2317.

Smith, D.C., D'Hondt, S., 2006. Life in deep subseafloor sediments. Oceanography 19, 58-70. 
Smith, K.L., Jr., Baldwin, R.J., Karl, D.M., Boetius, A., 2002. Benthic community responses to pulses in pelagic food supply: North Pacific Subtropical Gyre. Deep-Sea Research I 49, 971-990.

Smith, K.L., Jr., Baldwin, R.J., Ruhl, H.A., Kahru, M., Mitchell, B.G., Kaufmann, R.S., 2006. Climate effect on food supply to depths greater than 4,000 meters in the northeast Pacific. Limnology and Oceanography 51, 166-176.

Smith, K.L., Jr., Kaufmann, R.S., 1999. Long-term discrepancy between food supply and demand in the deep eastern North Atlantic. Science 284, 1174-1177.

Smith, K.L., Jr., Kaufmann, R.S., Baldwin, R.J., Carlucci, A.F., 2001. Pelagic-benthic coupling in the abyssal eastern North Pacific: An eight-year time-series study of food supply and demand. Limnology and Oceanography 46, 543-556.

Smith, K.L., Jr., Ruhl, H.A., Kaufmann, R.S., Kahru, M., 2008a. Tracing abyssal food supply back to upper-ocean processes over a 17-year time series in the northeast Pacific. Limnology and Oceanography 53, 2655-2667.

Smith, K.L., Jr., Williams, P.M., Druffel, E.R.M., 1989. Upward fluxes of particulate organic matter in the deep North Pacific. Nature 337, 724-726.

Smythe-Wright, D., Boswell, S., Kim, Y.-N., Kemp, A., 2010. Spatio-temporal changes in the distribution of phytopigments and phytoplanktonic groups at the Porcupine Abyssal Plain (PAP) site. Deep-Sea Research II 57, 1324-1335

Soetaert, K., van Oevelen, D., 2009. Modeling food web interactions in benthic deep-sea ecosystems: A practical guide. Oceanography 22, 130-145.

Sogin, M.L., Morrison, H.G., Huber, J.A., Welch, D.M., Huse, S.M., Neal, P.R., Arrieta, J.M., Herndl, G.J., 2006. Microbial diversity in the deep sea and the unexplored "rare biosphere". Proceedings of the National Academy of Sciences USA 103, 12115-12120.

Solheim, A., Bryn, P., Sejrup, H. P., Mienert, J., Berg, K., 2005. Ormen Lange - an integrated study for the safe development of a deep-water gas field within the Storegga Slide Complex, NE Atlantic continental margin; Executive summary. Marine and Petroleum Geology 22, 1-9.

Soltwedel, T., Bauerfeind, E., Bergmann, M., Budaeva, N., Hoste, E., Jaeckisch, N., von Juterzenka, K.v., Matthiessen, J., Mokievsky, V., Nöthig, E.-M., Quéric, N., Sablotny, B., Sauter, E., Schewe, I., Urban-Malinga, B., Wegner, J., WlodarskaKowalczuk, M., Klages, M., 2005. HAUSGARTEN: multidisciplinary investigations at a deep-sea, long-term observatory in the Arctic Ocean. Oceanography 18, 46-61.

Somavilla, R., González-Pola, C., Rodriguez, C., Josey, S.A., Sánchez, R.F., Lavín, A., 2009. Large changes in the hydrographic structure of the Bay of Biscay after the extreme mixing of winter 2005. Journal of Geophysical Research-Oceans 114, C01001, doi:10.1029/2008JC004974.

Somot, S., Sevault, F., Déqué, M., 2006. Transient climate change scenario simulation of the Mediterranean Sea for the twenty-first century using a high-resolution ocean circulation model. Climate Dynamics 27, 851-879.

Soter, S., 1999. Macroscopic earthquake precursors and submarine pockmarks in the CorinthPatras Rift, Greece. Tectonophysics 308, 275-290.

St Laurent, L.C., Thurnherr, A.M., 2007. Intense mixing of lower thermocline water on the crest of the Mid-Atlantic Ridge. Nature 448, 680-683.

Ståhl, H., Tengberg, A., Brunnegård, J., Hall, P.O.J., 2004. Recycling and burial of organic carbon in sediments of the Porcupine Abyssal Plain, NE Atlantic. Deep-Sea Research I 51, 777-791. 
Stenseth, N.C., Mysterud, A., Ottersen, G., Hurrell, J. W., Chan, K.-S., Lima, M., 2002. Ecological effects of climate fluctuations. Science 297, 1292-1296.

Stige, L.C., Ottersen, G., Brander, K. Chan, K.-S., Stenseth, N.C., 2006. Cod and climate: effect of the North Atlantic Oscillation on recruitment in the North Atlantic. Marine Ecology Progress Series 325, 227-241.

Stone, R., 2008. Sichuan disaster: Landslides, flooding pose threats as experts survey quake's impact. Science 320, 996- 997.

Stott, P.A., Sutton, R.T., Smith, D.M., 2008. Detection and attribution of Atlantic salinity changes. Geophysical Research Letters 35, L21702, doi:10.1029/2008GL035874.

Stramma, L., Johnson, G.C., Sprintall, J., Mohrholz, V., 2008. Expanding oxygen-minimum zones in the tropical oceans. Science 320, 655-658.

Stuut, J.B., Zabel, M., Ratmeyer, V., Helmke, P., Schefuß, E., Lavik, G., Schneider, R., 2005. Provenance of present-day eolian dust collected off NW Africa. Journal of Geophysical Research 110, doi:10.1029/2004JD005161.

Sutherland, W. J., Armstrong-Brown, S., Armsworth, P. R., Brereton, T., Brickland, J., Campbell, C. D., Chamberlain, D. E., Cooke, A. I., Dulvy, N. K., Dusic, N. R., Fitton, M., Freckleton, R. P., Godfray, C. J., Grout, N., Harvey, H. J., Hedley, C., Hopkins, J. J., Kift, N. B., Kirby, J., Kunin, W. E., MacDonald, D. W., Marker, B., Naura, M., Neale, R., Oliver, T., Osborn, D., Pullin, A. S., Shardlow, M. E. A., Showler, D. A., Smith, P. L., Smithers, R. J., Solandt, J. C., Spencer, J., Spray, C. J., Thomas, C. D., Thompson, J., Webb, S. E., Yalden, D. W., Watkinson, A. R., 2006. The identification of 100 ecological questions of high policy relevance in the UK. Journal of Applied Ecology 43, 617-627.

Tagliabue, A., Bopp, L., Dutay, J.-C., Bowie, A.R., Chever, F., Jean-Baptiste, P., Bucciarelli, E., Lannuzel, D., Remenyi, T., Sarthou, G., Aumont, O., Gehlen, M., Jeandel, C., 2010. Hydrothermal contribution to the oceanic dissolved iron inventory. Nature Geoscience 3, 252-256.

Tain, Z., Ollivier, P., Véron, A., Church, T.M., 2008. Atmospheric Fe deposition modes at Bermuda and the adjacent Sargasso Sea. Geochemistry Geophysics Geosystems 9, doi:10.1029/2007GC001868.

Takahashi, T., Sutherland, S.C., Sweeney, C., Poisson, A., Metzl, N., Tilbrook, B., Bates, N., Wanninkhof, R., Feely, R.A., Sabine, C., Olafsson, J., Nojiri, Y., 2002. Global sea-air $\mathrm{CO}_{2}$ flux based on climatological surface ocean $p \mathrm{CO}_{2}$, and seasonal biological and temperature effects. Deep-Sea Research II 49, 1601-1622.

Takahashi, T. ,Sutherland, S.C., Wanninkhof, R., Sweeney, C., Feely, R.A., Chipman, D., Hales, B., Friederich, G., Chavez, F., Watson, A., Bakker, D., Schuster, U., Metzl, N., Inoue, H.Y., Ishii, M., Midorikawa, T., Sabine, C., Hoppema, M., Olafsson, J., Amarson, T., Tilbrook, B., Johannessen, T., Olsen, A., Bellerby, R., DeBaar, H., Nojiri, Y., Wong, C.S., Delille, B., Bates, N., 2009. Climatological mean and decadal change in surface ocean $p \mathrm{CO}_{2}$, and net sea-air $\mathrm{CO}_{2}$ flux over the global oceans. Deep-Sea Research II 56, 554-577.

Talley, L.D., 2003. Shallow, intermediate and deep overturning components of the global heat budget. Journal of Physical Oceanography 33, 530-560.

Taupier-Letage, I., Puillat, I., Millot, C., Raimbault, P., 2003. Biological response to mesoscale eddies in the Algerian Basin. Journal of Geophysical Research 108, 3245, doi:10.1029/1999JC000117.

Test, T., Langone, L., Goni, M.A., Turchetto, M., Miserocchi, S., Boldrin, A., 2008. Source and composition of organic matter in the Bari canyon (Italy): Dense water cascading versus particulate export from the upper ocean. Deep-Sea Research I 55, 813-831. 
Thiel, H., Kirstein, K.O., Luth, C., Luth, U., Luther, G., Meyer-Reil, L.A., Pfannkuche, O., Weydert, M., 1994. Scientific requirements for an abyssal benthic laboratory. Journal of Marine Systems 4, 421-439.

Thomas, H., Prowe, A.E.F., Lima, I., Doney, S.C., Wanninkhof, R., Schuster, U., Corbiére, A., 2008. Changes in the North Atlantic Oscillation influence $\mathrm{CO}_{2}$ uptake in the North Atlantic over the past 2 decades. Global Biogeochemical Cycles 22, GB4027, doi:10.1029/2007GB003167.

Tinti, S., Maramai, A., Graziani, L., 2004. The new catalogue of Italian Tsunamis. Natural Hazards 33, 439-465.

Toggweiler, J.R., Samuels, B., 1995. Effect of sea ice on the salinity of Antarctic bottom waters. Journal of Physical Oceanography 25, 1980-1997.

Trenberth K.E., M. Balmaseda, N.L. Bindoff, J. Church, H. J. Freeland, G. Lagerloef, R. S. Nerem, M. Palmer, S. Rintoul, D. Roemmich, C. L. Sabine, D. Stammer, P. Stott, 2010. Intergovernmental Panel for Climate Change (IPCC) and attribution and prediction of climate: Progress since the fourth assessment. In Hall, J., Harrison D.E. Stammer, D. (Eds.), Proceedings of the OceanObs’09: Sustained Ocean. Observations and Information for Society conference 2, Venice, Italy, 21-25 September 2009, ESA Publication WPP-306.

Trimborn, S., Langer, G., Rost, B., 2007. Effect of varying calcium concentrations and light intensities on calcification and photosynthesis in Emiliania huxleyi. Limnology and Oceanography 52, 2285-2293.

Troupin, C., Sangrà, P., Arístegui, J., 2010, Seasonal variability of the oceanic upper layer and its modulation of biological cycles in the Canary Island region. J. Mar. Sys. 80, 172-183.

Tryon, M., Brown, K., Dorman, L., Sauter, A., 2001. A new benthic aqueous flux meter for very low to moderate discharge rates. Deep-Sea Research 48, 2121-2146.

Tudhope, A.W., Scoffin, T.P. 1995. Processes of sedimentation in Gollum Channel, Porcupine Seabight: submersible observations and sediment analyses, Trans. R. Soc. Edinburgh Earth Sci. 86, 49-55.

Tyrrell, T., 2008. Calcium carbonate cycling in future oceans and its influence on future climates. Journal of Plankton Research 30, 141-156.

Tyack, P.L., Clark, C.W., 2000. Communication and acoustic behavior of dolphins and whales. pp. 156-224. In: Au, W., Popper, A.N., and Fay, R. (Eds.). Hearing by whales and dolphins. Springer Handbook of Auditory Research Series. New York: Springer Verlag. U.S.DoI-MMS/U.S. Department of the Interior - Minerals Management Service - Gulf of Mexico OCS Region 2004: Geological and Geophysical Exploration for Mineral Resources on the Gulf of Mexico Outer Continental Shelf - Final Programmatic Environmental Assessment. - OCS EIS/EA, MMS 2004-054, 487 pp.

US Geological Survey, 2008. International Registry of Seismograph Stations website (http://neic.usgs.gov/neis/station_book/) (update of U.S. Geological Survey OpenFile Report 85-719, Seismograph Station Codes and Coordinates, 1985 Edition)

Våge, K., Pickart, R.S., Thierry, V., Reverdin, G., Lee, C.M., Petrie, B., Agnew, T.A., Wong, A., Ribergaard, M.H., 2009. Surprising return of deep convection to the subpolar North Atlantic Ocean in winter 2007-2008. Nature Geoscience 2, 67-72.

Van Dover, C.L., German, C.R., Speer, K.G., Parson, L.M., Vrijenhoek, R.C., 2002. Evolution and biogeography of deep-sea vent and seep invertebrates. Science 295, 1253-1257.

van Oevelen D., Duineveld. G., Lavaleye, M., Mienis, F., Soetaert, K., Heip, C.H.R., 2009. The cold-water coral community as a hot spot for carbon cycling on continental 
margins: A food-web analysis from Rockall Bank (northeast Atlantic). Limnol. Oceanogr. 54, 1829-1844.

van Weering, T.C.E., de Stigter, H.C., Boer, W., de Haas, H., 2002. Recent sediment transport and accumulation on the NW Iberian margin. Progress in Oceanography 52, 349371.

Vaulot, D., Lebot, N., Marie, D., Fukai, E., 1996. Effect of phosphorus on the Synechococcus cell cycle in surface Mediterranean waters during summer. Appl. Environ. Microbiol. 62, 2527-2533.

Vellinga, M., Wood, R.A., 2002. Global climatic impacts of a collapse of the Atlantic thermohaline circulation. Climatic Change 54, 251-267.

Vergnaudgrazzini, C., Caralp, M., Faugeres, J.C., 1989. Mediterranean outflow through Strait of Gibraltar since 18000 BP. Oceanologica 12, 305-324.

Visbeck, M.H., Hurrell, J.W., Polvani, L., Cullen, H.M., 2001. The North Atlantic Oscillation: Past, present, and future. Proceedings of the National Academy of Sciences USA 98, 12876-12877.

Volk, T., Hoffert, M.I., 1985. Ocean carbon pumps: Analysis of relative strengths and efficiencies in ocean-driven atmospheric $\mathrm{CO}_{2}$ changes. In: Sundquist, E.T., Broecker, W.S., (Eds.) The carbon cycle and atmospheric $\mathrm{CO}_{2}$ : Natural variations Archean to present. Geophysical Monograph Series 32, pp. 99-110., AGU, Washington, DC.

Wade, I.P., Ellett, D.J., Heywood, K.J., 1997. The influence of intermediate waters on the stability of the eastern North Atlantic. Deep-Sea Research I 44, 1405-1426.

Waldmann, C. et al. Assessment of sensor performance, Ocean Sci., 6, 235-245, 2010 http://www.ocean-sci.net/6/235/2010/os-6-235-2010.pdf

Weaver, P.P.E., Gunn, V., 2009. Introduction to the special issue: HERMES-Hotspot Ecosystem Research on the Margins of European Seas. Oceanography 20, 12-15.

Wentz, F.J., Ricciardulli, L., Hilburn, K., Mears, C., 2007. How much more rain will global warming bring? Science 317, 233-235.

Westbrook, G.K., Thatcher, K.E., Rohling, E.J., Piotrowski, A.M., Pälike, H., Osborne, A., Nisbet, E.G., Minshull, T., Lanoisellé, M., James, R.H., Hühnerbach, V., Green, D., Fisher, R.E., Chabert, A., Bolton, C., Beszczynska-Möller, A., Berndt, C., Aquilina, A., 2009. Escape of methane gas from the seabed along the West Spitsbergen continental margin. Geophysical Research Letters 36, L15608, doi:10.1029/2009GL039191.

Williamson, S.J., Cary, S.C., Williamson, K.E., Helton, R.R., Bench, S.R., Winget, D., Wommack, K.E., 2008. Lysogenic virus-host interactions predominate at deepsea diffuse-flow hydrothermal vents. ISME Journal 2, 1112-1121.

Wilson, S.E., Steinberg, D.K., 2010, Autotrophic picoplankton in mesozooplankton guts: evidence of aggregate feeding in the mesopelagic zone and export of small phytoplankton. Mar. Ecol. Prog. Ser. 412, 11-27.

Wilson, R.W., Millero, F J., Taylor, J.R., Walsh, P.J., Christensen, V., Jennings, S., Grosell, M., 2009. Contribution of fish to the marine inorganic carbon cycle. Science 323, 359-362.

Witte, U., Wenzhöfer, F., Sommer, S., Boetius, A., Heinz, P., Aberle, N., Sand, M., Cremer, A., Jørgensen, B.B., Pfannkuche, O., 2003. In situ experimental evidence of the fate of a phytodetritus pulse at the abyssal sea floor. Nature 424, 763-766.

Woods, J.D., 1985. Physics of thermocline ventilation. In: Nihoul, J.C.J. (Ed.), Coupled ocean-atmospheric models, Elsevier, Amsterdam. 
Woodside, J.M., David, L., Frantzisc, A., Hooker, S.K., 2006. Gouge marks on deep-sea mud volcanoes in the eastern Mediterranean: Caused by Cuvier's beaked whales? Deep-Sea Research I 53, 1762-1771.

Würsig, B., Richardson, W.J. 2002. Effects of noise. In: Perrin, W.F., Würsig, B., and Thewissen, J.G.M. (Eds.) The encyclopaedia of marine mammals. Academic Press, New York, pp. 794-802.

Yalçıner, A.C., Alpar, B., Altinok, Y., Ozbay, I., Imamura, F., 2002. Tsunamis in the Sea of Marmara: Historical documents for the past, models for future. Marine Geology 190, 445-463.

Ye, Y., Völker, C., Wolf-Gladrow, D.A., 2009. A model of Fe speciation and biogeochemistry at the Tropical Eastern North Atlantic Time-Series Observatory site. Biogeosciences 6, 2041-2061.

Yin, J., Schlesinger, M.E., Stouffer, R.J., 2009. Model projections of rapid sea-level rise on the northeast coast of the United States. Nature Geoscience 2 262-266.

Yool, A., Martin, A.P., Fernández, C., Clark, D.R., 2007. The significance of nitrification for oceanic new production. Nature 447, 999-1002.

Yool, A., Shepherd, J.G., Bryden, H.L., Oschlies, A., 2009. Low efficiency of nutrient translocation for enhancing oceanic uptake of carbon dioxide. Journal of Geophysical Research 114, (C8), C08009. (doi:10.1029/2008JC004792).

Zeebe, R.E., Zachos, J.C., Caldeira, K., Tyrrell, T., 2008. Carbon emissions and acidification. Science 321, 51-52.

Zachos, J.C., Dickens, G.R., Zeebe, R.E., 2008. An early Cenozoic perspective on greenhouse warming and carbon-cycle dynamics. Nature 451, 279-283.

Zenk W., Morozov, E., 2007. Decadal warming of the coldest Antarctic Bottom Water flow through the Vema Channel. Geophysical Research Letters 34, 14, L14607, doi.10.1029/2007GL03034.

Zickfeld, K., Eby, M., Weaver, A.J., 2008. Carbon-cycle feedbacks of changes in the Atlantic meridional overturning circulation under future atmospheric $\mathrm{CO}_{2}$. Global Biogeochemical Cycles 22, GB3024, doi:10.1029/2007GB003118.

Zitter, T.A.C., Henry, P., Aloisi, G., Delaygue, G., Çağatay, M.N., Mercier de Lepinay, B., Al-Samir, M., Fornacciari, F., Tesmer, M., Pekdeger, A., Wallmann, K., Lericolais, G., 2008. Cold seeps along the main Marmara Fault in the Sea of Marmara (Turkey). Deep-Sea Research I 55, 552-570.

Zondervan, I., Zeebe, R.E., Rost, B., Riebesell, U., 2001. Decreasing marine biogenic calcification: A negative feed-back on rising atmospheric $p \mathrm{CO}_{2}$. Global Biogeochemical Cycles 15, 507-516.

Zondervan, I., Rost, B., Riebesell, U., 2002. Effect of $\mathrm{CO}_{2}$ concentration on the PIC/POC ratio in the coccolithophore Emiliania huxleyi grown under light-limiting conditions and different daylengths. Journal of Experimental Marine Biology and Ecology 272, 55-70.

Zwiers, F, Hegerl, G., 2008. Attributing cause and effect. Nature 453, 296-297. 
Figure 1. Illustration of the overlapping scales of major ocean and earth processes. Figure adapted from work of D. Chelton, (Oregon State University), L. Beranzoli (Istituto Nazionale di Geofisica e Vulcanologia), and Dickey and Chang (2001). In colour

Figure 2. Illustration of major processes in the marine environment indicating the interconnectedness of atmospheric, surface ocean, biological pump, deep-sea, and solid-Earth dynamics. This figure is based on other similar figures prepared by $\mathrm{P}$. Cochonat, C. Berndt, ESONET NoE, and the US Ocean Observatories Initiative.

Figure 3. Illustration showing general locations of proposed ESONET observatory nodes and the biogeochemical provinces of Longhurst (2006). Provinces shown include Boreal Polar (BPLR), Atlantic Arctic (ARCT), Atlantic Subarctic (SARC), the North Atlantic Drift (NADR), Northeast Atlantic Continental Shelf (NECS), North Atlantic Subtropical Gyre East (NASW), and Mediterranean (MEDI). Map projection from Google Earth. In colour

Figure 4. Illustrations of (upper panel) regional plate stress where warmer colours indicate greater stress, and (lower panel) relative plate motion for the European region with motion represented as vector arrows (sensu Kreemer et al. 2003, illustrations created at http://jules.unavco.org/Voyager/Earth). In colour

Figure 5. a) Location of survey area west of Svalbard; IBCAO bathymetry (Jakobsson et al., 2008). b) Positions of plumes of bubbles acoustically imaged with the EK60 sonar, depicted by "pins", superimposed on perspective view of the bathymetry of part of the area of plume occurrence. Bathymetry is from EM120 multibeam survey of cruise JR211 gridded at 20-m resolution, combined with high-resolution survey data from the Norwegian Hydrographic Service for the shallower-than-200-m part of the map. The 396-m isobath is the expected landward limit of the GHSZ. c) Part of record from an EK60 acoustic survey from JR211, showing examples of observed plumes. Amplitude of acoustic response is given by the colour of the "bubbles". All plumes show a deflection towards the north caused by the West Svalbard Current. The seabed, at around 240-m depth, is shown by the strong (red) response. The position of CTD cast 10 is indicated by vertical red arrow. Figure and legend from Westbrook et al. (2009). In colour

Figure 6. Time-series data from Station M (a.k.a. Mike) in Nordic Sea showing a) salinity, b) temperature anomalies with depth. Figure courtesy of S. Østerhus, Bjerknes Centre for Climate Research. In colour

Figure 7. Potential temperature time series (colour shading) in the upper $1800 \mathrm{~m}$ of the central Labrador Sea (after Avsic et al. 2006). The black dots in colour contour indicate the 30 days average instruments depth. After a period of deep convection with an associated cooling of the water column at the beginning of the 1990's a distinct warming since 1997 can be seen. Stick plot of currents at approximately 250m depth is indicated at top panels, while gray shading indicate periods with current speed larger $20 \mathrm{~cm} / \mathrm{sec}$ often associated with the passage of transient eddies. In colour

Figure 8. Estimated change in sea surface $\mathrm{pH}$ from the pre-industrial period (1700s) to the present day (1990s). $\Delta \mathrm{pH}$ here is in standard $\mathrm{pH}$ units. This change is caused by 
the invasion of anthropogenic $\mathrm{CO}_{2}$. Calculated using Richard Zeebe's csys package with data from the Global Ocean Data Analysis Project and World Ocean Atlas climatologies. $\Delta \mathrm{pH}$ is plotted here using a Mollweide projection (using MATLAB and the M_Map package). Note that the GLODAP climatology is missing data in certain oceanic provinces including the Arctic Ocean, the Caribbean Sea, the Mediterranean Sea and the Malay Archipelago. Legend and image courtesy of Andrew Yool. In colour

Figure 9. A) Sea-surface temperature and B) near surface Chl- $a$ concentrations in the Tropical Northeast Atlantic from MODIS satellite retrievals. The 8-day averaged data (16. May 2004 to 23. May 2004) is interpolated to a $4000 \mathrm{~m}$ horizontal grid. The figures illustrate how complex relations between the physical and biological parameters can be. In colour

Figure 10. This double unit figure (both acoustic spectral density and actual levels) relates ocean noise, hearing thresholds and the audibility of some specific sources. The two heavy-lined curves show (in black) a typical ocean ambient noise power spectral density and (in blue) the corresponding audibility threshold for odontocetes, mostly taken from dolphin data, as no large whale audiogram is yet known. Some estimates of received sound pressure levels from specific anthropogenic sources at example ranges are shown as large blue dots or horizontal bars towards the top of the figure. The transmission loss calculations for these are based on spherical and/or cylindrical spreading (as appropriate for the waveguide) and absorption; source levels range between 190 and $210 \mathrm{~dB}$ re $1 \mu \mathrm{Pa} @ 1 \mathrm{~m}$ for instruments and 210-240dB for long range low-frequency military sonar. The light blue boxes (whose vertical size and position is arbitrary) display the frequency range of some natural sources in the horizontal. Figure is from E. Delory's PhD thesis and builds upon an original version published in (Potter and Delory, 1998). In colour

Figure 11. Climatic and abyssal time-series data for Station $\mathrm{M}$ in the NE Pacific and PAP in the NE Atlantic with A) the ENSO indicator the Northern Oscillation Index (NOI) with monthly (light dashed line) and 13-month running mean (compound line), and POC flux to $4050 \mathrm{~m}$ depth at Sta. M; B) mobile epibenthic megafauna variation at Sta. M including Elpidia minutissima abundance (crosses), Echinocrepis rostrata abundance (open circles), and an index of species composition similarity of the top ten most abundant epibenthic megafauna (solid circles); C) the North Atlantic Oscillation (NAO) index with monthly (light dashed line) and 13-month running mean (compound line), and POC flux to $3000 \mathrm{~m}$ depth at the PAP; and D) total megafauna variation at Sta. M including Oneirophanta mutabilis abundance (crosses), Amperima rosea abundance (open circles), and an index of species composition similarity of the benthic megafauna (solid circles). Figure and legend from Glover et al. 2010).

Figure 12. A) Corals above fresh pillow lava in a hydrothermal vent field (Menez Gwen), B) Flange structure at Lucky Strike hydrothermal vent field colonized by the mussel Bathymodiolus azoricus with some vent shrimps, C) Sulphide structure colonized by the mussel (adults and juveniles) Bathymodiolus azoricus, with the fish Gaidropsaurus mauli on the fissure. All images (c) Missão Seahma. 2002 (FCT/PCDTM 1999MAR/15281) In colour 
Figure 13. Developing data management structure for European open-ocean observatories. The lowermost area shows the standards and interfaces, which are sensor related and the line represents the internet. Network connected and delayed mode data enter the scheme through the internet and SOS using O\&M to encode the data itself. This data is archived in the data centres, represented to the right. SOS uses SensorML to identify and describe the observatory capacities. Capacities are also stored in the Sensor Registry and can be queried there via C$\mathrm{SW}$. SensorML is used to generate metadata for data archiving. The uppermost part of the figure shows the user perspective, the data portal and knowledge base.

Figure 14. A map of circulation $14 \mathrm{C}$ age below $1500 \mathrm{~m}$. This is equivalent to conventional $14 \mathrm{C}$ age, but accounts for surface ocean $14 \mathrm{C}$ reservoir age and the different sources of deep water. Unit is years. Legend and figure courtesy of $\mathrm{K}$. Matsumoto (@ American Geophysical Union, 2007). In colour 


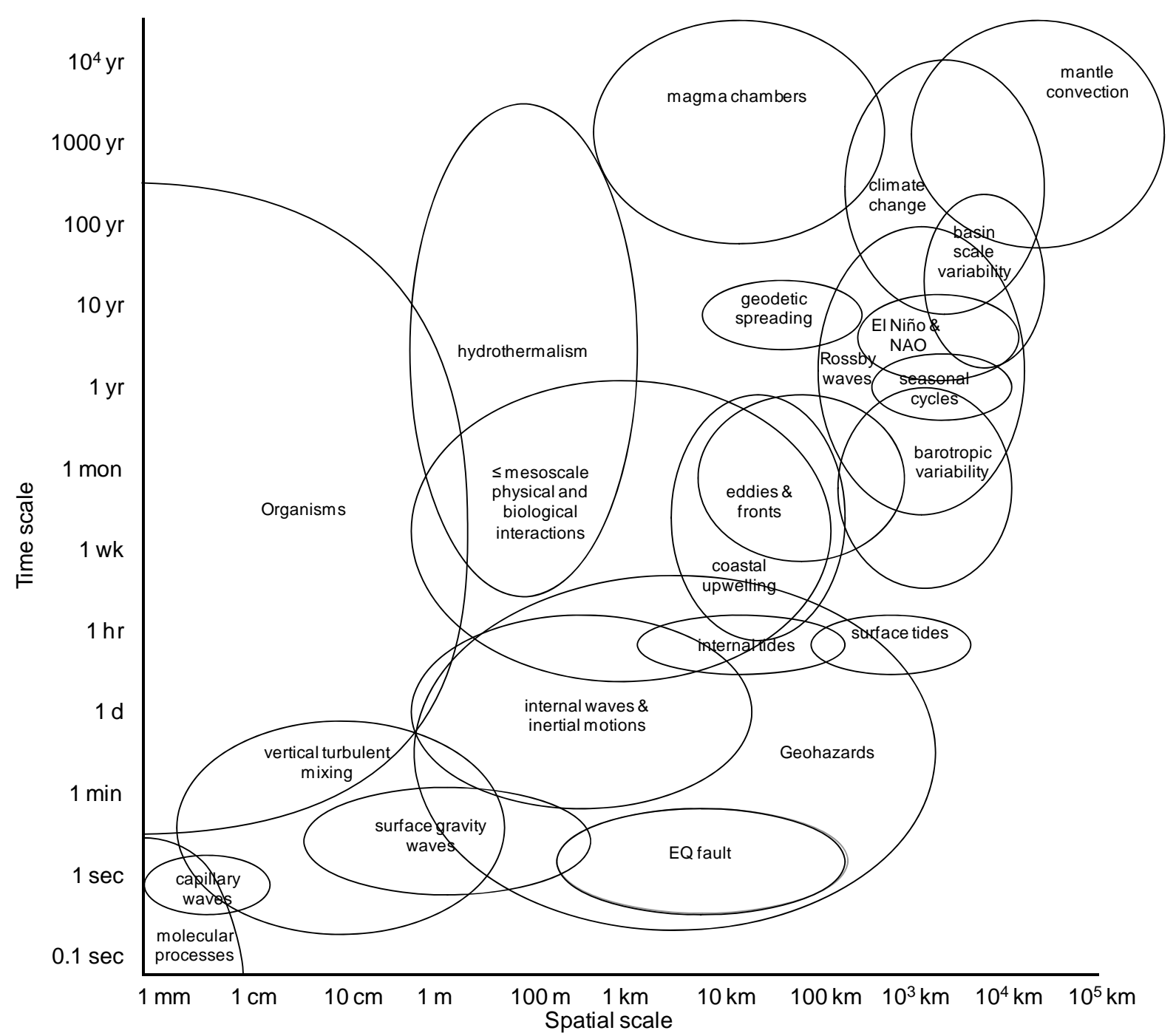

Figure 1. 


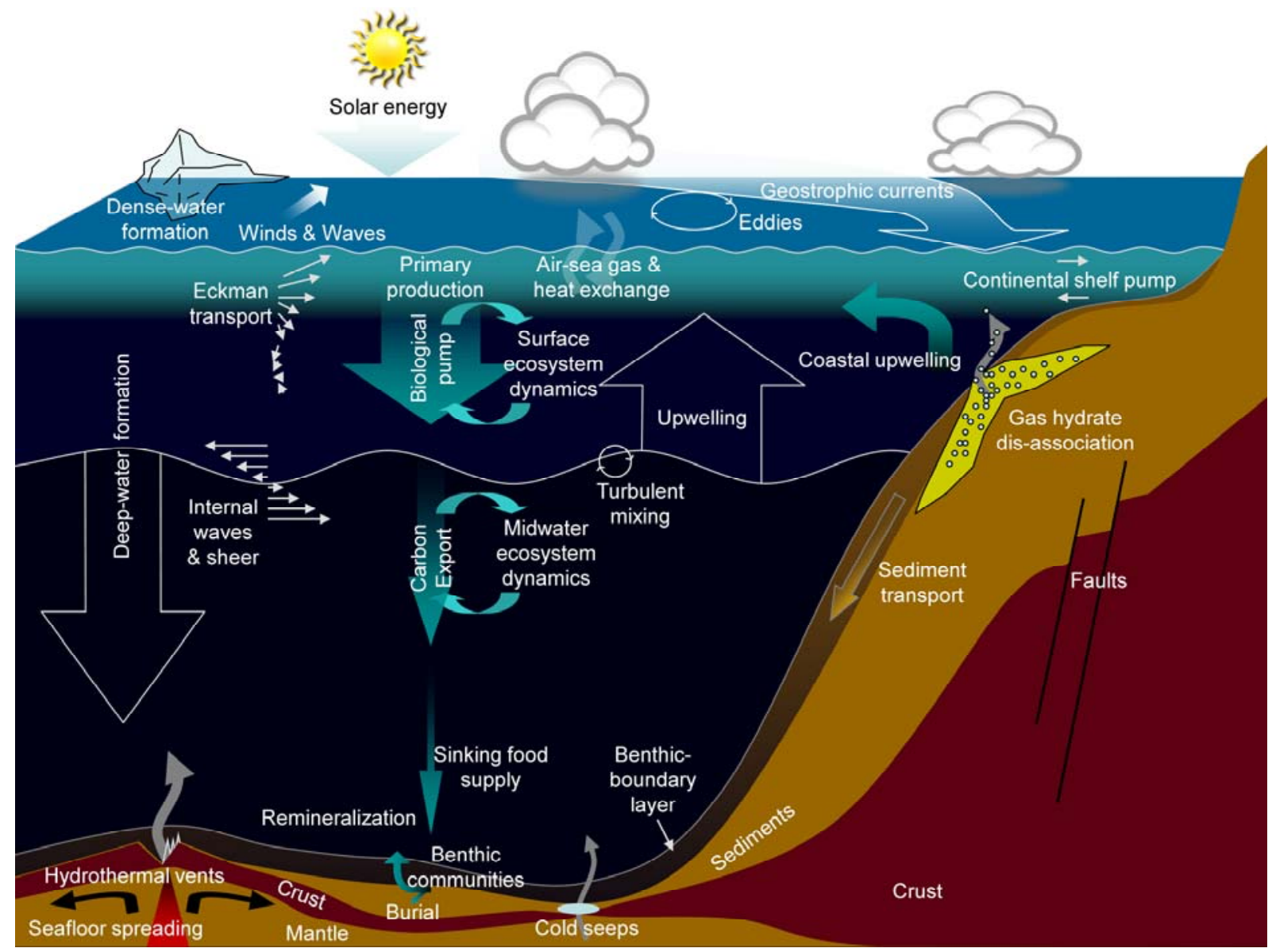

Figure 2 


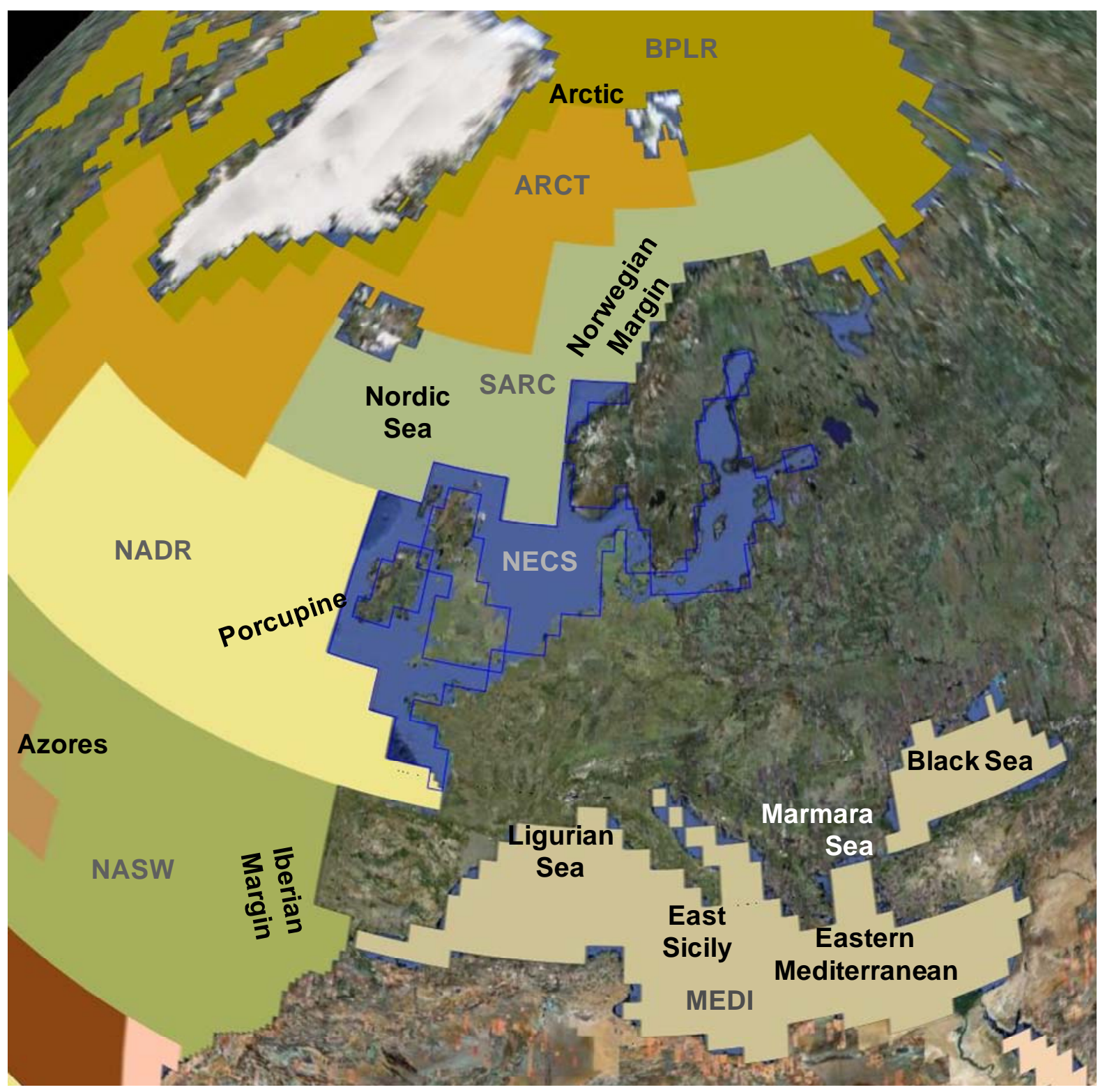

Figure 3 


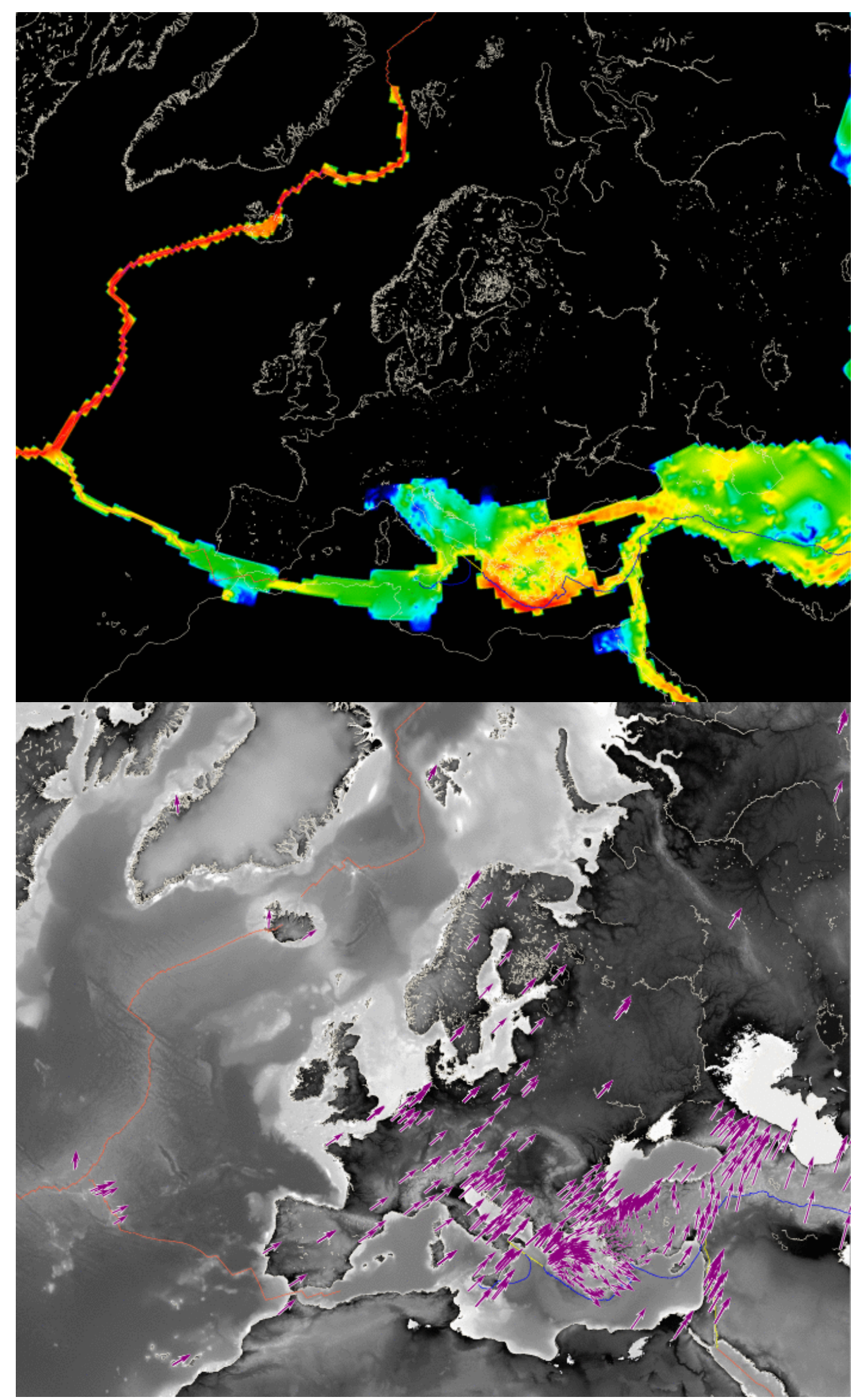

Figure 4 


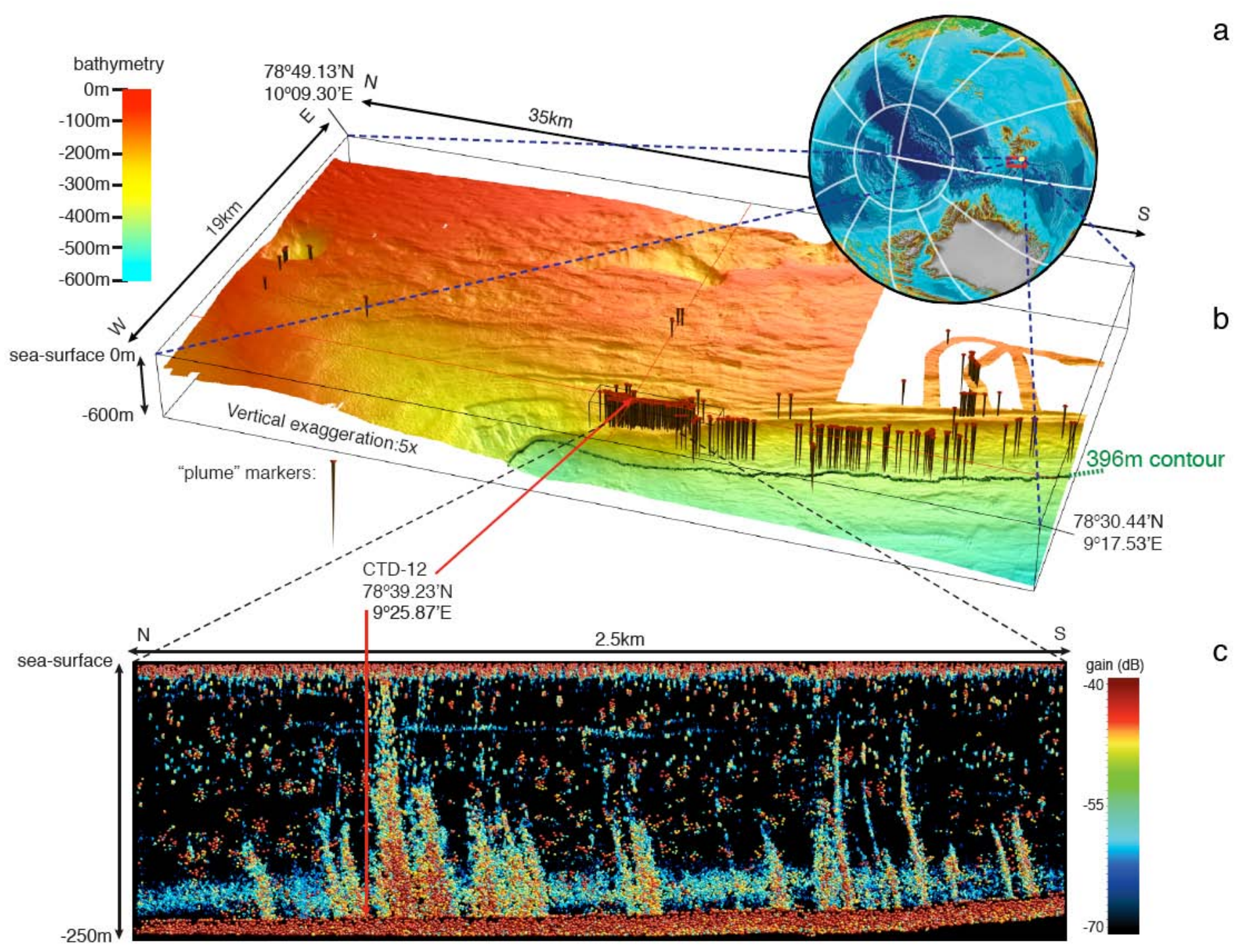

Figure 5 
A)

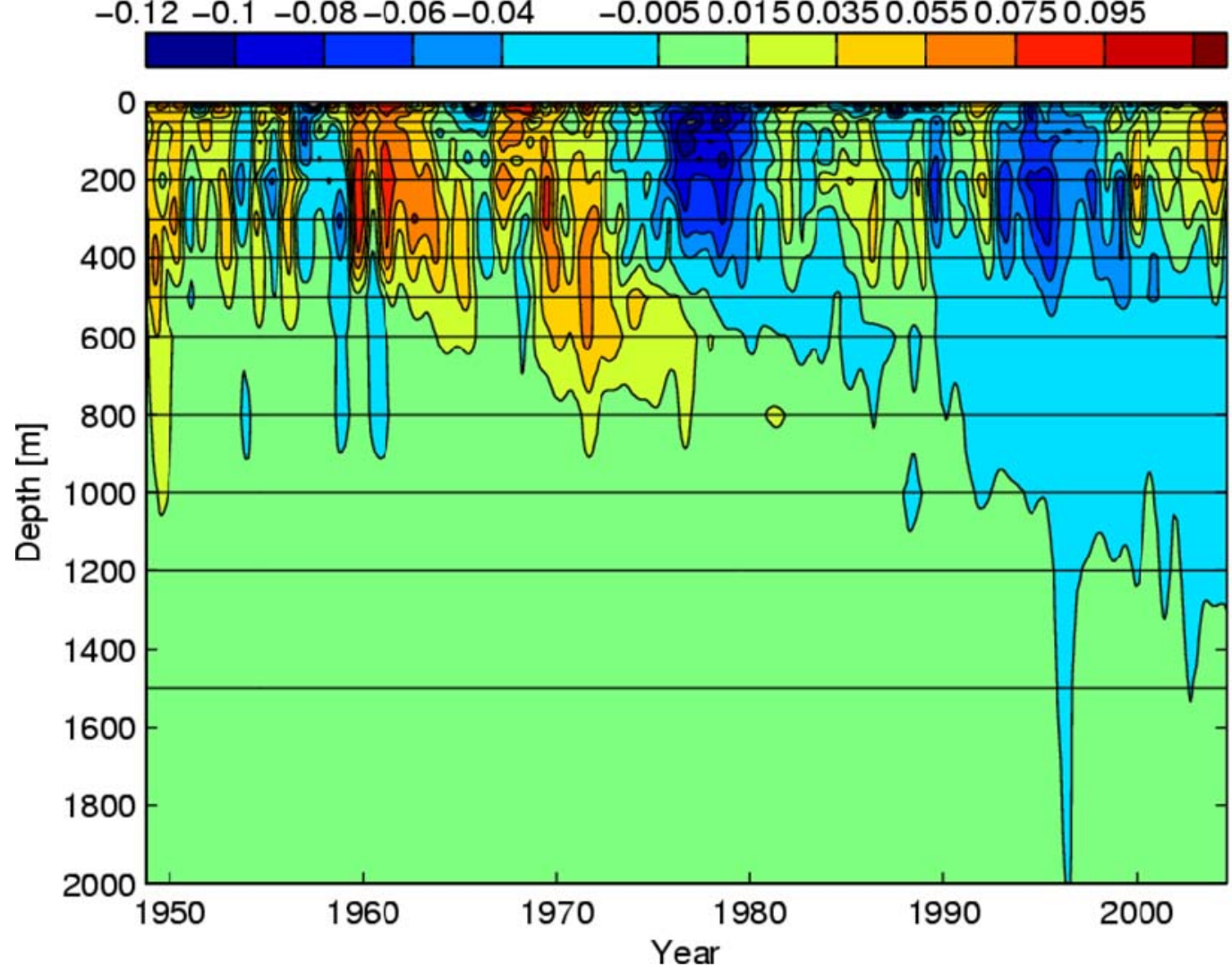

B)

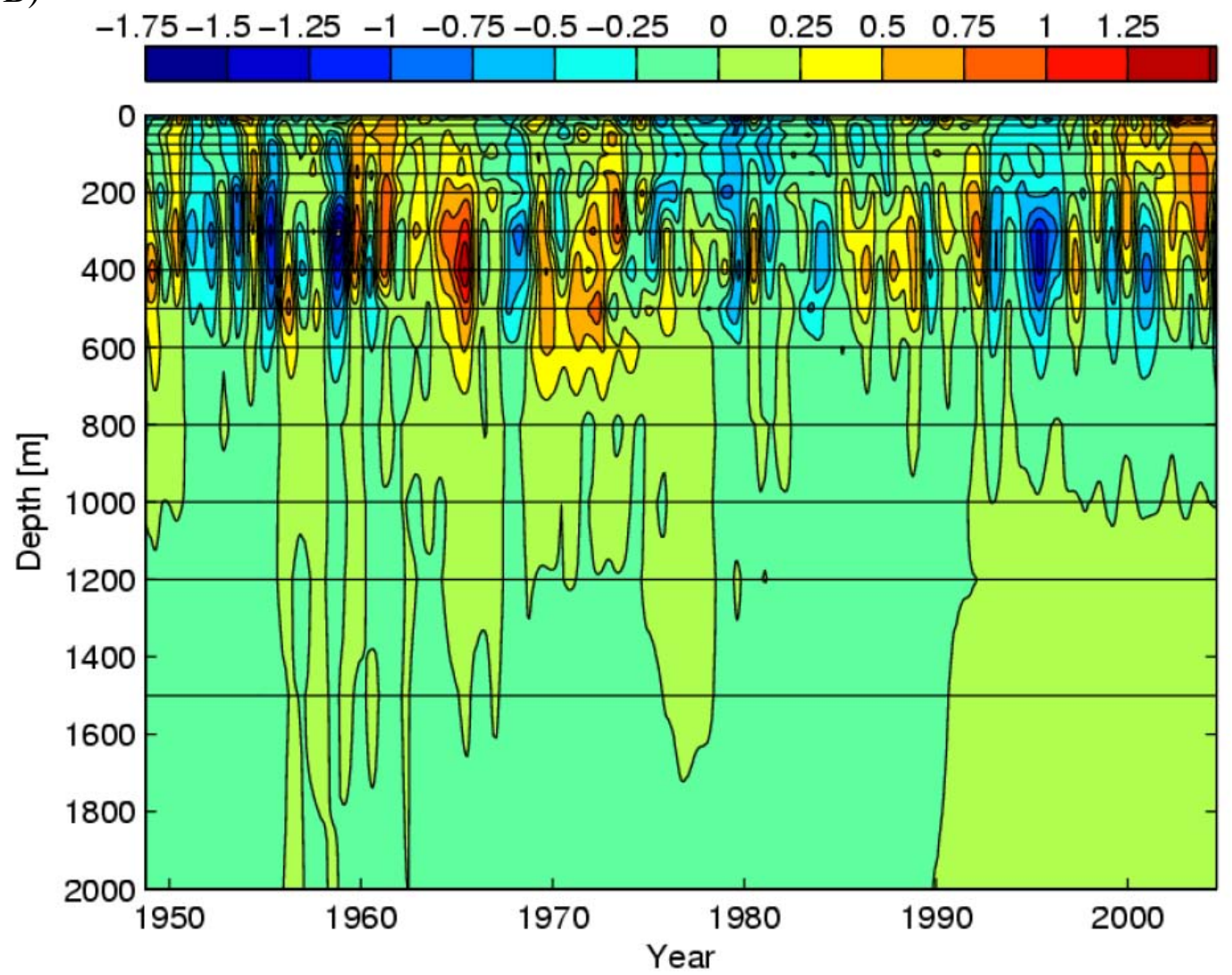

Figure 6 


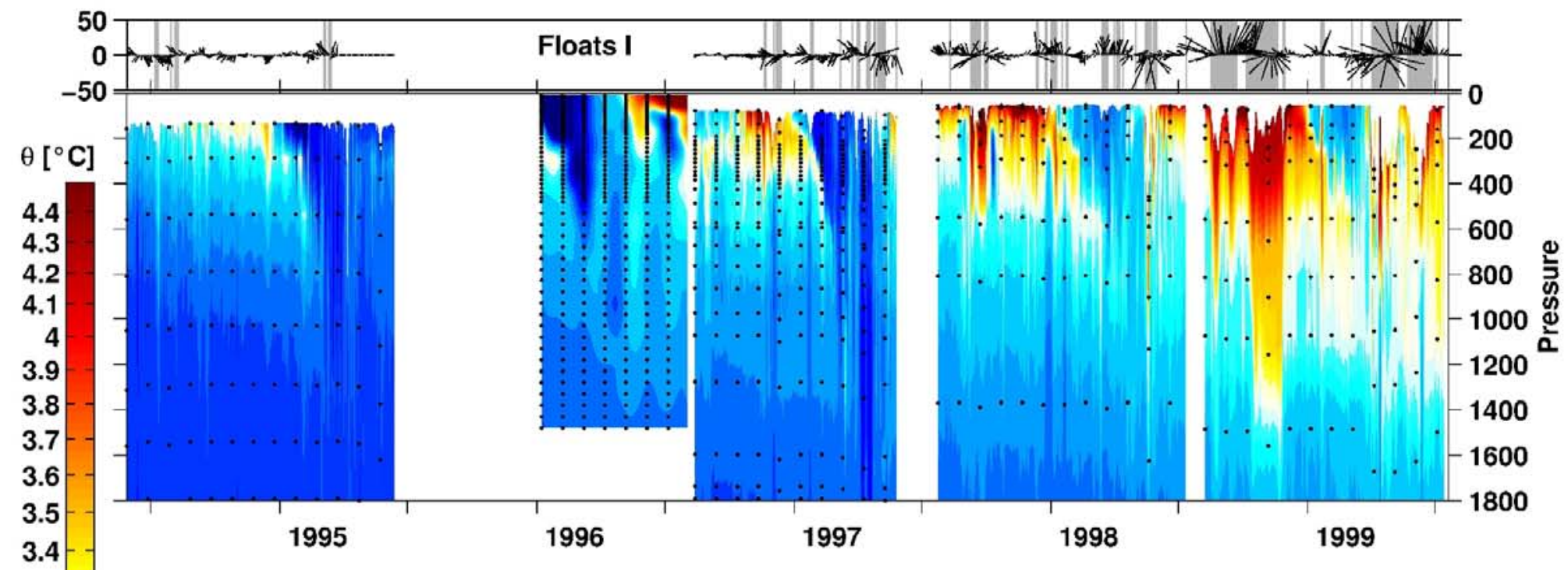

3.3

3.2

3.1 -

3

2.9

2.8

2.7

2.6

2.5

2.4

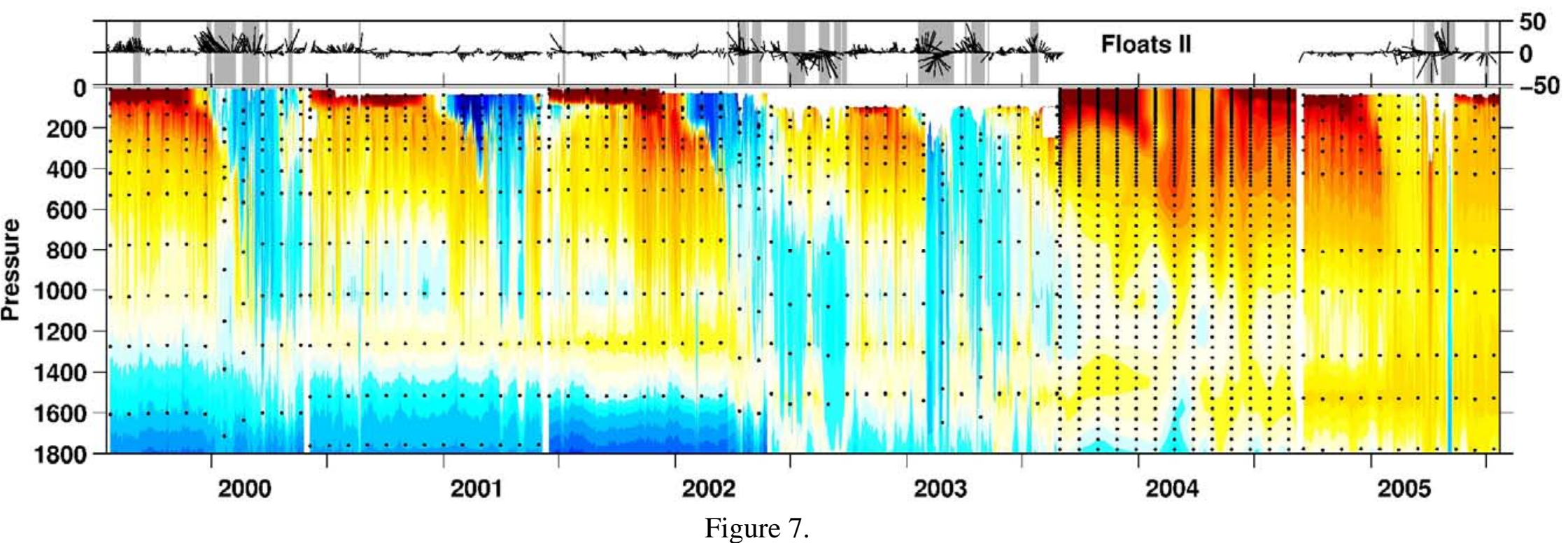




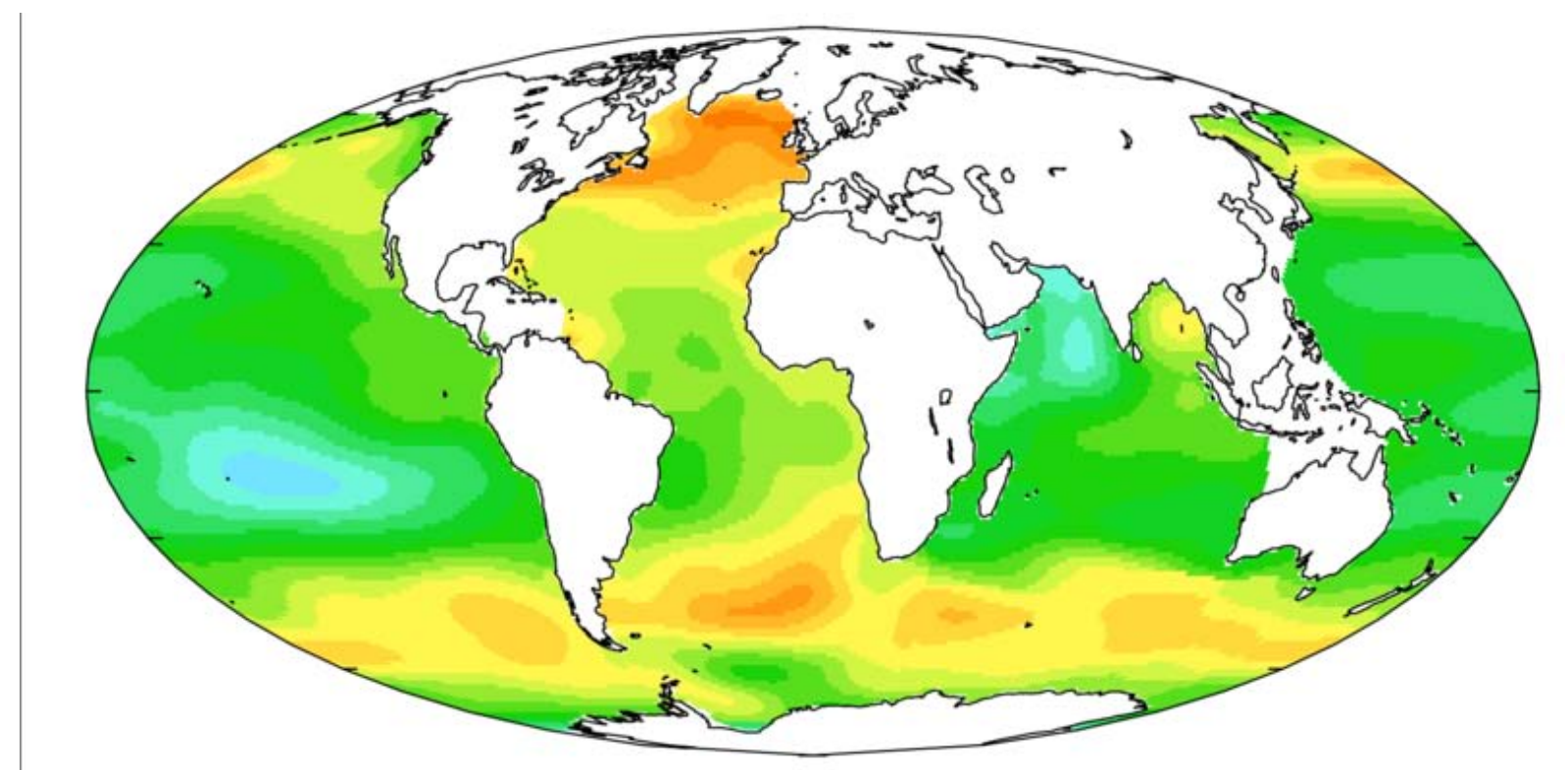

$\Delta$ sea-surface $\mathrm{pH}[-]$

\begin{tabular}{rrrrrrr} 
& & & & & & \\
-0.12 & -0.1 & -0.08 & -0.06 & -0.04 & -0.02 & 0 \\
\hline
\end{tabular}




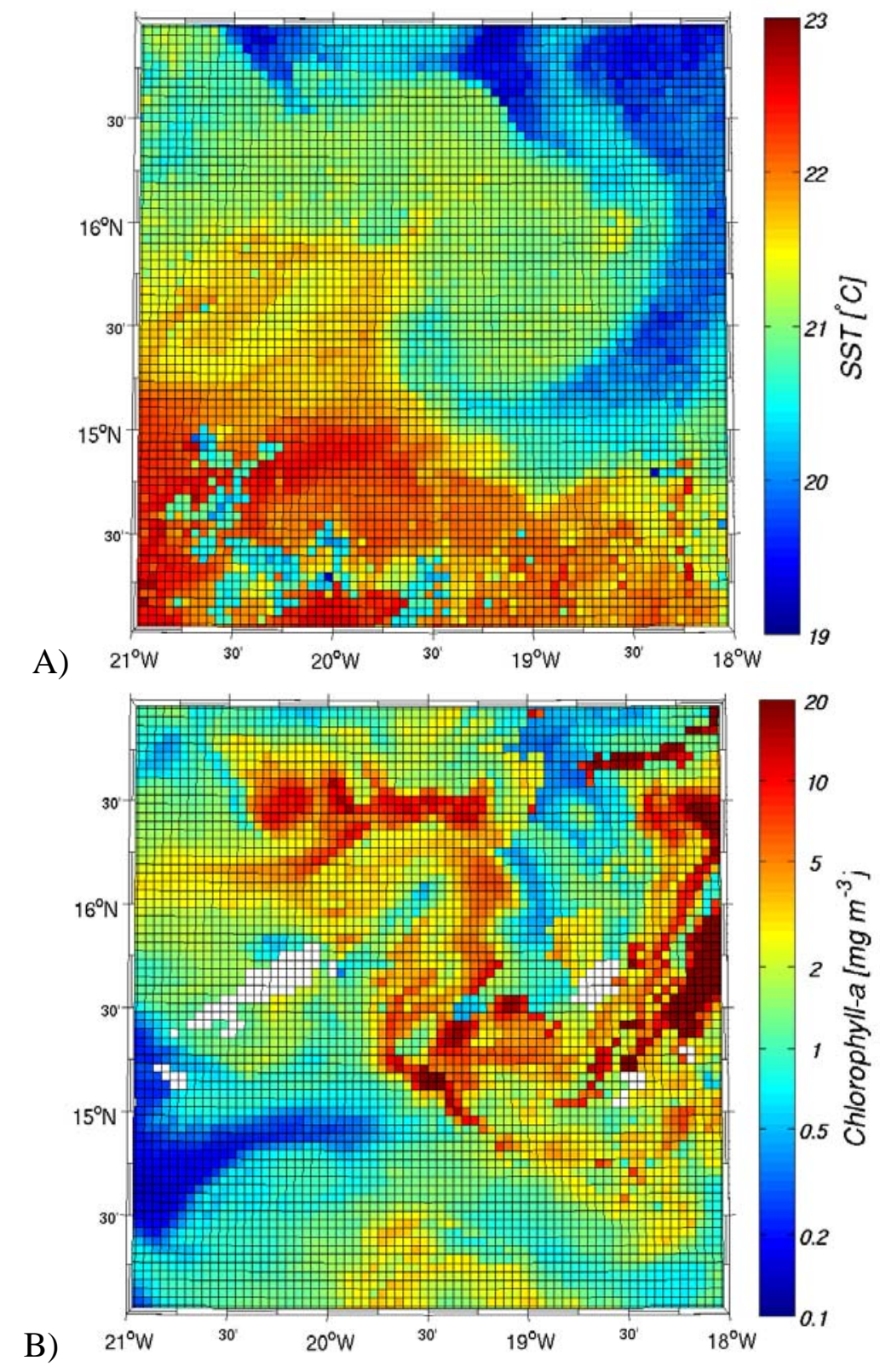

Figure 9.

Figure 8 


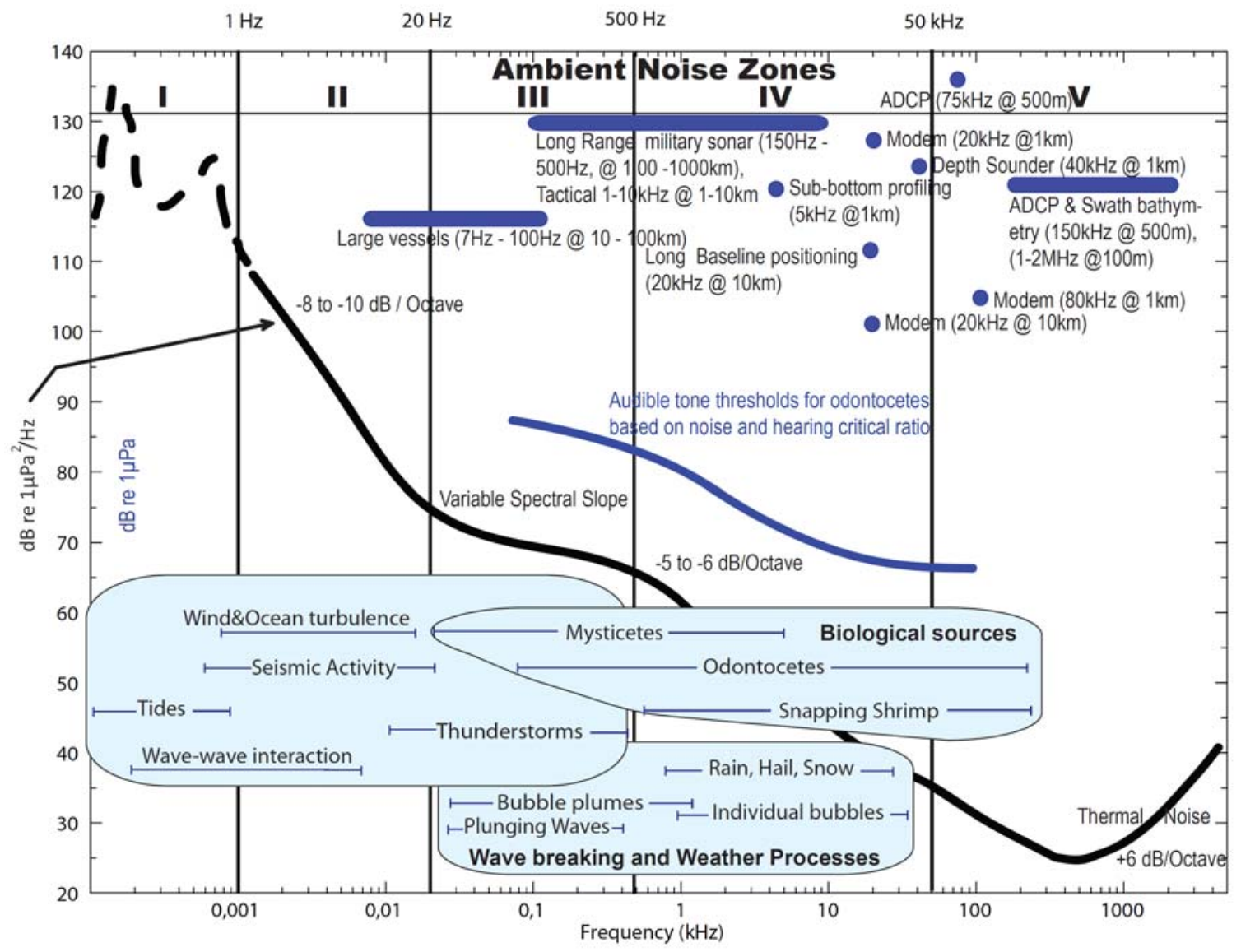

Figure 10 

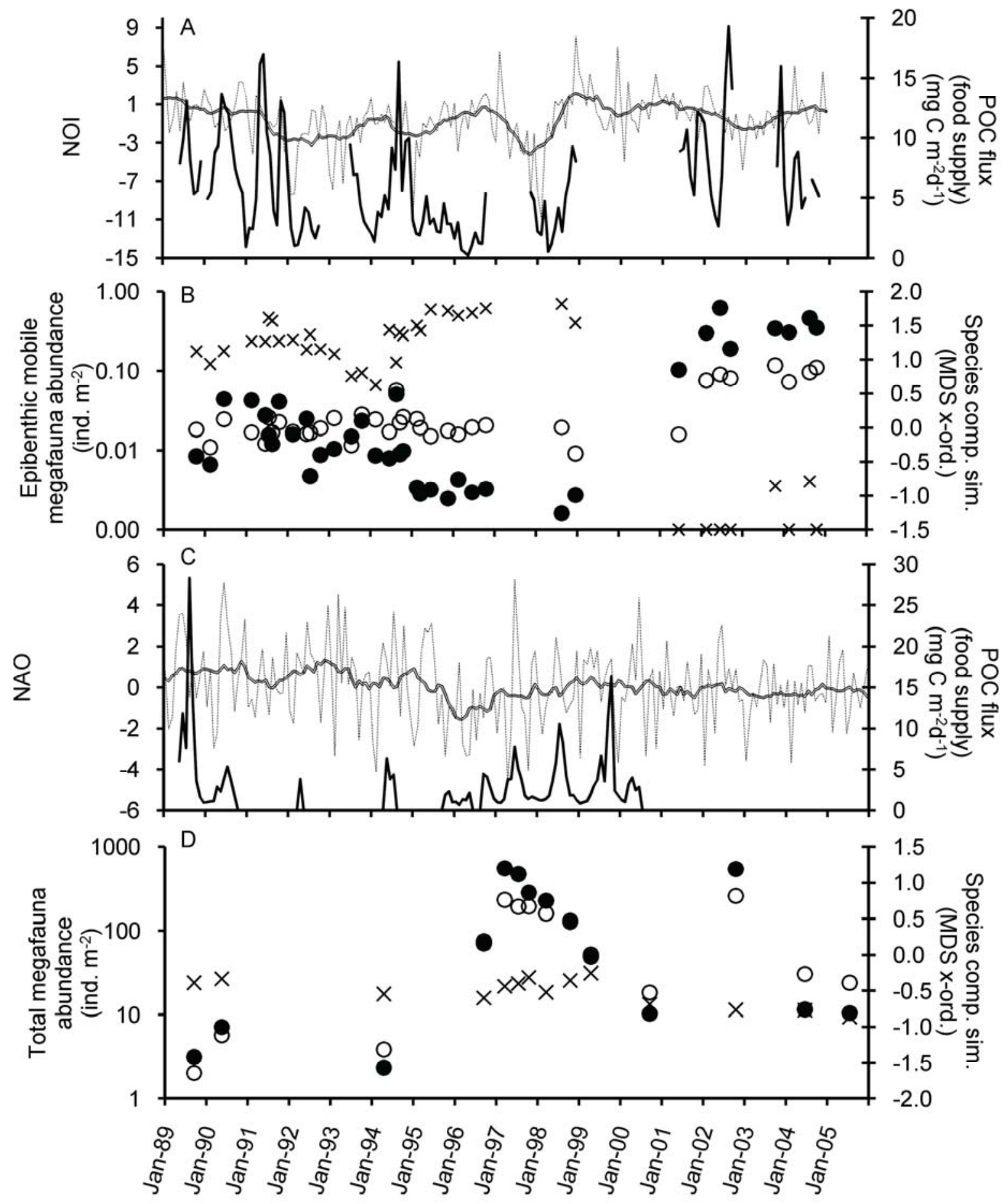

Figure 11 

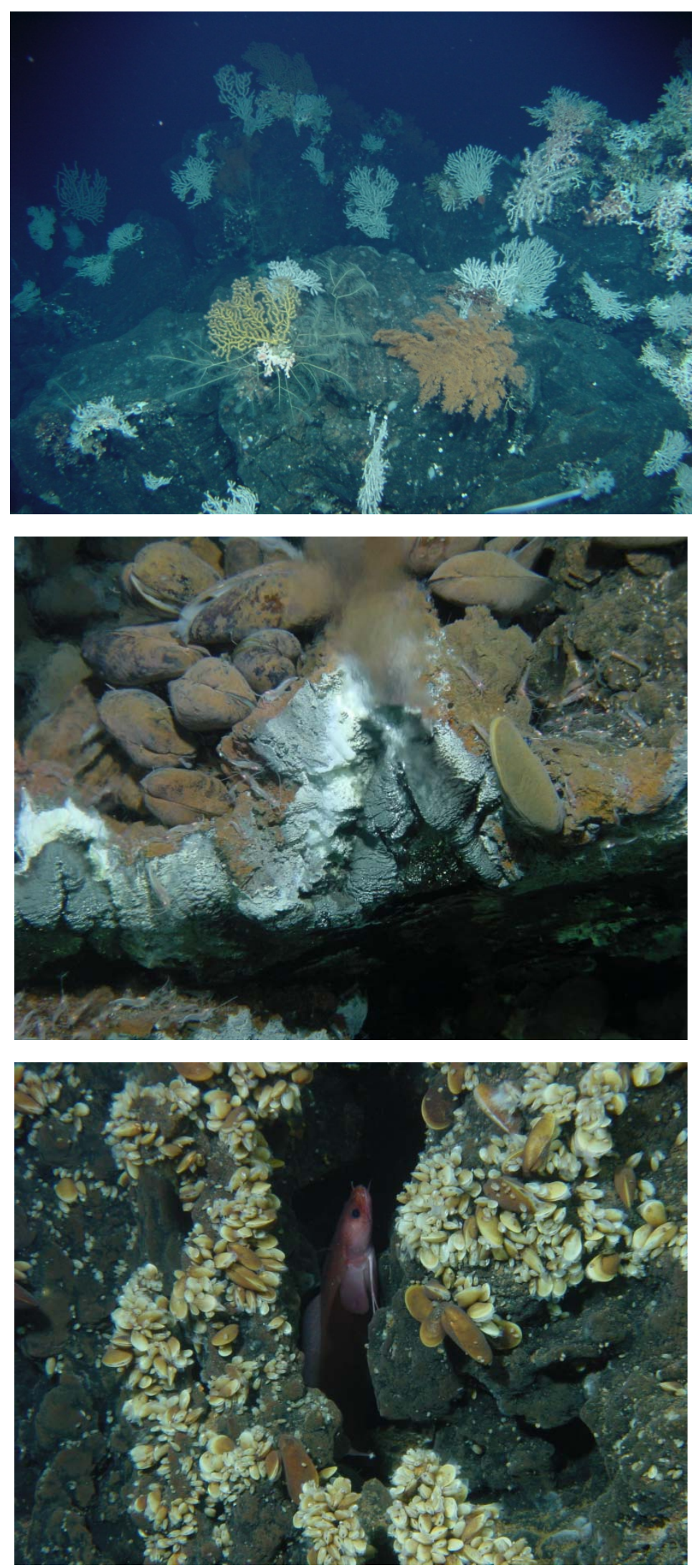

Figure 12 


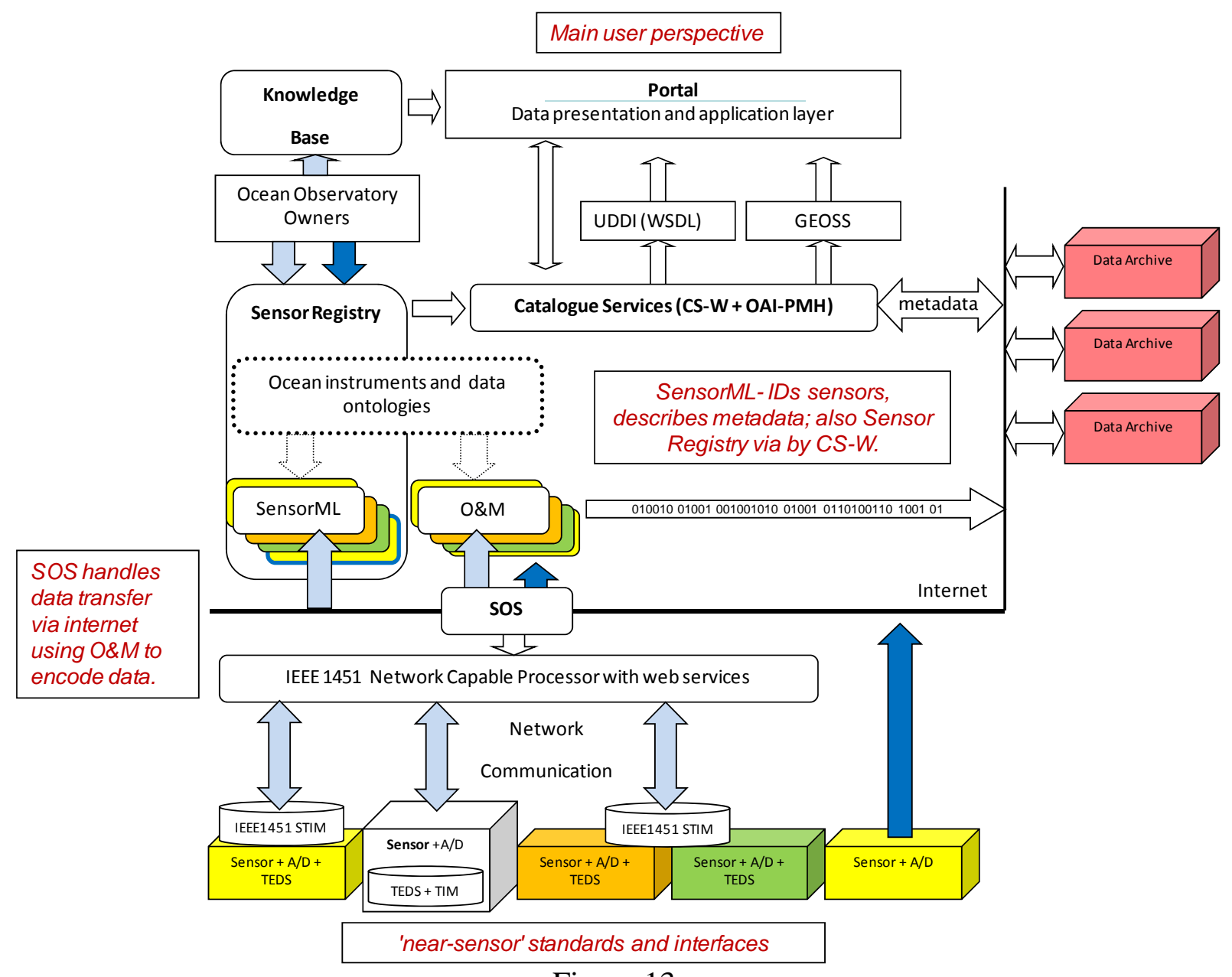

Figure 13. 


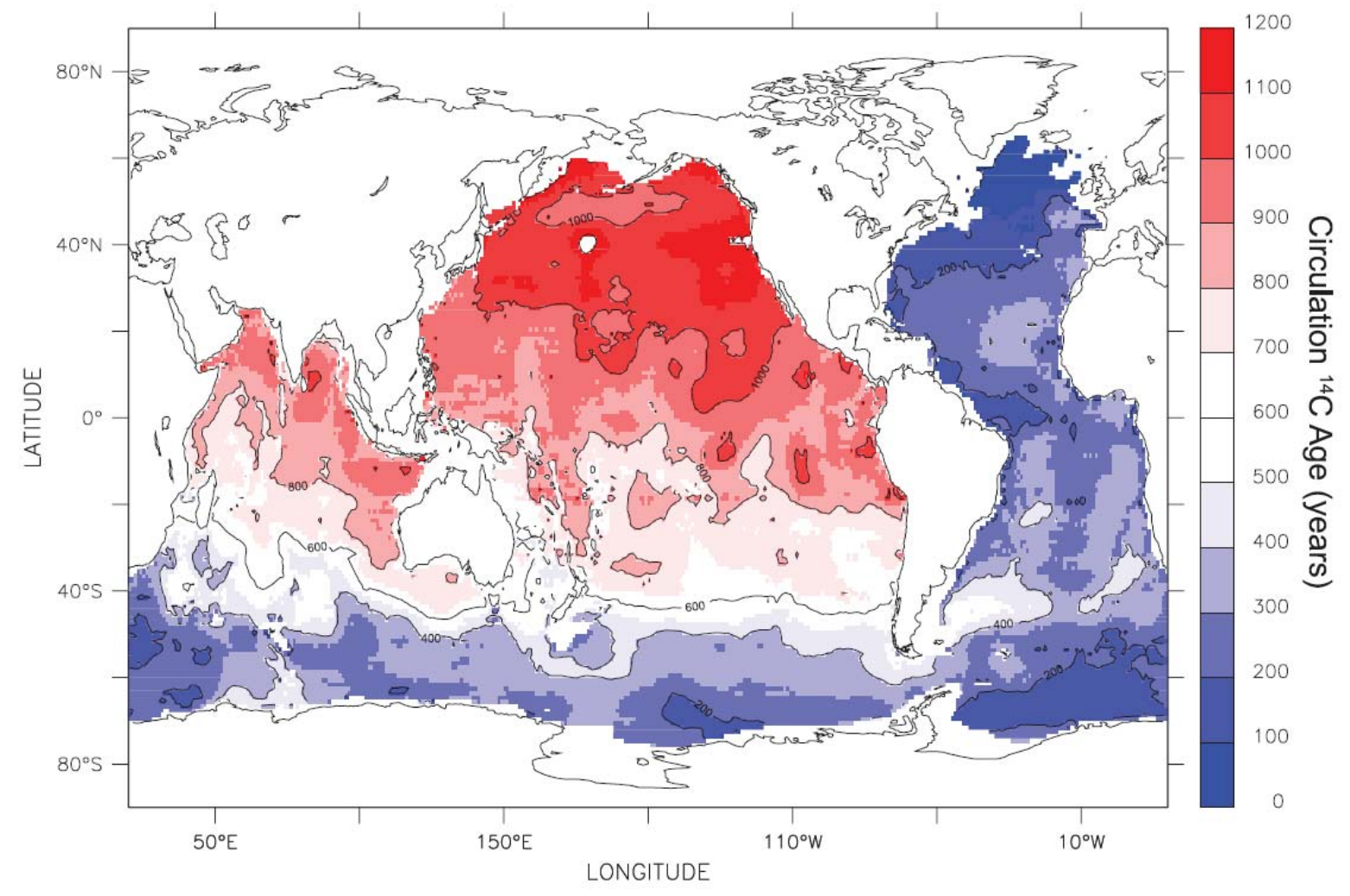

Figure 14 
Table 1. National and international projects and programmes with topics that relate to ocean observatory efforts.

Table 2. Connections between forcing factors, supporting and utilized services, and socioeconomic impacts, as well as how these relate to policy and ocean observatory science which describes links between forcing and services and thereby informs societal policy. This table was adapted from the similar relationships outlined by the United Nations Environment Programme, HERMES, and the Center for Ocean Solutions ( UNEP 2007, Center for Ocean Solutions 2009, Grehan et al. 2009). In Colour

Table 3. Overview of minimum specifications under consideration for in generic sensor modules that may be used across European ocean observatory sites 
Table 1

\begin{tabular}{|c|c|}
\hline Short name & Name or description \\
\hline ANTARES & Astronomy with a Neutrino Telescope and Abyss environmental RESearch \\
\hline Argo & Broad-scale global array of temperature and salinity profiling floats \\
\hline BATS & Bermuda Atlantic Time Series \\
\hline CarboOcean & Marine carbon sources and sinks assessment \\
\hline DAMOCLES & $\begin{array}{l}\text { Developing Arctic Modeling and Observing Capabilities for Long-term } \\
\text { Environmental Studies }\end{array}$ \\
\hline DELOS & Deep-ocean Environmental Long-term Observatory System \\
\hline DONET & Dense Oceanfloor Network System for Earthquakes and Tsunamis \\
\hline EMODNET & European Marine Observation and Data Network \\
\hline EMSO & European Multidisciplinary Seafloor Observatory \\
\hline EPOCA & European Project on OCean Acidification \\
\hline EPOS & European Plate Observing System \\
\hline ESFRI & European Strategy Forum on Research Infrastructures \\
\hline ESONET CA & European Seafloor Observatory NETwork Concerted Action \\
\hline ESONET NoE & European Seas Observatory NETwork Network of Excellence \\
\hline ESONIM & ESONET Network Implementation Model \\
\hline Eur-OCEANS & EURopean network of excellence for OCean Ecosystems ANalysis \\
\hline EuroSITES & $\begin{array}{l}\text { European Ocean Observatory Network, The European contribution to } \\
\text { OceanSITES }\end{array}$ \\
\hline EXOCET-D & EXtreme ecosystem studies in the deep OCEan: Technological Developments \\
\hline GEOSS & Global Earth Observation System of Systems \\
\hline GEOSTAR & Geophysical and Oceanographic Station for Abyssal Research \\
\hline GMES & Global Monitoring for Environment and Security \\
\hline GITEWS & German Indonesian Tsunami Early-Warning System (GITEWS) \\
\hline HERMES & Hotspot Ecosystem Research on the Margins of European Seas \\
\hline HERMIONE & Hotspot Ecosystem Research and Man's Impact on European Seas \\
\hline HYPOX & $\begin{array}{l}\text { In situ monitoring of oxygen depletion in hypoxic ecosystems of coastal and } \\
\text { open sea, \& land locked water bodies }\end{array}$ \\
\hline IMBER & Integrated Marine Biogeochemistry and Ecosystem Research \\
\hline IOC & Intergovernmental Oceanographic Commission \\
\hline KM3NeT & Kilometre-cube Underwater Neutrino Telescope \\
\hline $\mathrm{MACHO}$ & Marine Cable Hosted Observatory \\
\hline MarBEF & Marine Biodiversity and Ecosystem Functioning \\
\hline MERSEA & Marine Environment and Security for the European Area \\
\hline MGE & Marine Genomics in Europe \\
\hline MOMARNET & $\begin{array}{l}\text { Monitoring deep sea floor hydrothermal environments on the Mid-Atlantic } \\
\text { Ridge :A Marie Curie Research Training NETwork }\end{array}$ \\
\hline MyOcean & The implementation project of the GMES Marine Core Service \\
\hline NEAMTWS & $\begin{array}{l}\text { North East Atlantic, Mediterranean and connected seas Tsunami Warning } \\
\text { System }\end{array}$ \\
\hline NEAREST & Integrated observations from NEAR shorE Sources of Tsunamis \\
\hline NEMO & NEutrino Mediterranean Observatory \\
\hline NEPTUNE Canada & The NorthEast Pacific Time-Series Undersea Networked Experiments \\
\hline OceanSITES & A worldwide system of deepwater reference stations \\
\hline OOI & US National Science foundation Ocean Observatories Initiative \\
\hline RAPID-WATCH & Monitoring the Atlantic Meridional Overturning Circulation \\
\hline OCB & US Ocean Carbon and Biogeochemistry programme \\
\hline SeaDataNet & Pan-European infrastructure for ocean and marine data management \\
\hline SIOS & Svalbard Integrated Arctic Earth Observing System \\
\hline SOLAS & Surface Ocean Lower Atmosphere Study \\
\hline WSO & Western Shelf Observatory (Ireland and United Kingdom) \\
\hline THOR & Thermohaline Overturning - at Risk? \\
\hline
\end{tabular}


Table 2

\begin{tabular}{|c|c|c|c|}
\hline Forcing factor & Supporting services & Socio-economic services & Socio-economic impacts \\
\hline $\begin{array}{l}\text { Natural disasters } \\
\text { Climate change } \\
\text { Ocean warming } \\
\text { Ocean acidification } \\
\text { Storm intensity } \\
\text { Seafloor stability } \\
\text { Sea-level rise } \\
\text { Overfishing } \\
\text { Pollution } \\
\text { Habitat destruction } \\
\text { Acoustic noise }\end{array}$ & $\begin{array}{l}\text { Photosynthetic production } \\
\text { Chemosynthetic production } \\
\text { Nutrient cycling } \\
\text { Carbon sequestration \& storage } \\
\text { Biodiversity resilience } \\
\text { Habitat } \\
\text { Sediment transport } \\
\text { Organic matter transport } \\
\text { Geomorphology }\end{array}$ & $\begin{array}{l}\text { Provisioning services } \\
\text { Food resources } \\
\text { Hydrocarbon energy } \\
\text { Minerals } \\
\text { Genetic resources } \\
\text { Chemical recourses } \\
\text { Waste disposal sites } \\
\text { Regulating services } \\
\text { Water circulation \& exchange } \\
\text { Climate \& weather regulation } \\
\text { Carbon sequestration \& storage } \\
\text { Waste absorption \& detoxification } \\
\text { Biological control of harmful species } \\
\text { Geoengineering } \\
\text { Cultural services } \\
\text { Employment } \\
\text { Education } \\
\text { Scientific advancement } \\
\text { Quality of life } \\
\text { Recreation }\end{array}$ & $\begin{array}{l}\text { Increased geohazard risk } \\
\text { Reduced biogeochemical pump efficiency } \\
\text { Respiratory stress } \\
\text { Altered heat and nutrient transport } \\
\text { Heath risks from toxic compounds } \\
\text { Food web destabilization } \\
\text { Habitat loss } \\
\text { Human and animal migration } \\
\text { Reduced tourism, recreation, aesthetics } \\
\text { Food security } \\
\text { Marine-related industry activity }\end{array}$ \\
\hline
\end{tabular}

Table 3

\begin{tabular}{|c|c|c|c|}
\hline Type of sensor & Range $^{\dagger}$ & Accuracy $^{\dagger}$ & Sampling frequency \\
\hline Conductivity & 0 to $9 \mathrm{~S} / \mathrm{m}$ & $0.001 \mathrm{~S} / \mathrm{m}$ & $4 \mathrm{~Hz}^{*}$ \\
\hline Temperature & -5 to $+35^{\circ} \mathrm{C}$ & $0.01 \mathrm{~K}$ & $4 \mathrm{~Hz}^{*}$ \\
\hline Pressure & 0 to 600 bar & $0.1 \%$ FSR & $4 \mathrm{~Hz}^{*}$ \\
\hline Dissolved oxygen & 0 to $500 \mu \mathrm{M}$ & $5 \%$ & $0.01 \mathrm{~Hz}^{*}$ \\
\hline Carbon dioxide & 0 to $\geq 600 \mathrm{ppm}$ & $1 \mathrm{ppm}$ & $1 \mathrm{~min}$ \\
\hline Turbidity & 0 to 150 NTU & $10 \%$ & $1 \mathrm{~Hz}^{*}$ \\
\hline Chl-a fluorescence $e^{\ddagger}$ & 0 to $\geq 100 \mu \mathrm{g} / \mathrm{l}$ & $5 \%$ & $1 \mathrm{~min}$ \\
\hline Currents & 0 to $2 \mathrm{~m} / \mathrm{s}$ & $2 \%$ & $1 \mathrm{~Hz}^{*}$ \\
\hline Passive acoustics & 50 - $180 \mathrm{~dB}$ re $1 \mu \mathrm{Pa}$ & $+/-3 \mathrm{~dB}$ & $96 \mathrm{KHz}$ \\
\hline Time-lapse camera $\#$ & Colour & 5 Megapixels & hourly \\
\hline
\end{tabular}

${ }^{\dagger}$ Range and accuracy are given are often adjustable through calibration and given here as suggestions.

*High-frequency only needed for a few applications (i.e. those related to turbulence)

${ }^{\ddagger}$ Suggested for near surface stations

${ }^{\sharp}$ Suggested for benthic stations 